University of Louisville

ThinkIR: The University of Louisville's Institutional Repository

Electronic Theses and Dissertations

1938

\title{
A brief survey of Chinese immigrants in American life.
}

Chwen Kiang Djang

University of Louisville

Follow this and additional works at: https://ir.library.louisville.edu/etd

Part of the Race and Ethnicity Commons

\section{Recommended Citation}

Djang, Chwen Kiang, "A brief survey of Chinese immigrants in American life." (1938). Electronic Theses and Dissertations. Paper 1777.

https://doi.org/10.18297/etd/1777

This Master's Thesis is brought to you for free and open access by ThinkIR: The University of Louisville's Institutional Repository. It has been accepted for inclusion in Electronic Theses and Dissertations by an authorized administrator of ThinkIR: The University of Louisville's Institutional Repository. This title appears here courtesy of the author, who has retained all other copyrights. For more information, please contact thinkir@louisville.edu. 
NAME OF STUDENT:

TITLE OF THESIS :

NAME OF DIRECTOR:
CHWEN KIANG DJANG

A BRIEF SURVEY OF CHINESE IMMIGRANTS IN AMERICAN LIFE

DR. ROBERT I. KUTAK

APPROVED BY A READING COMMITTEE COMPOSED OF THE FOLLOWING MEMBERS:

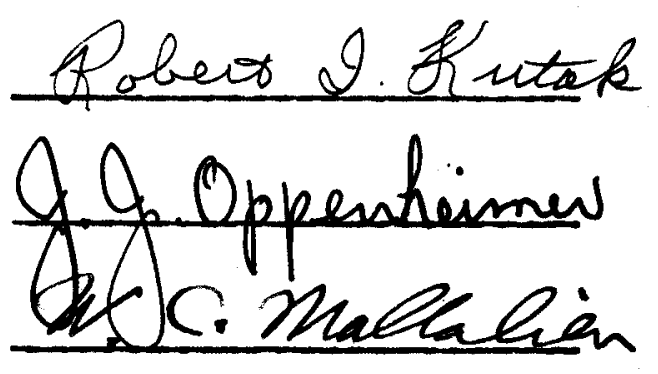

REPRESENTATIVE OF THE DEPARTMENT OF ENGLISH:

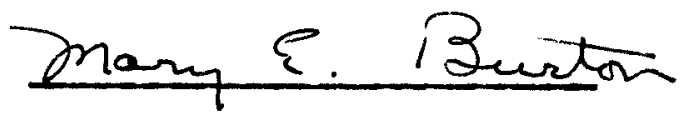

DATE: JULY 15,1938 
Within the four seas all are brethren....

- Confuc1us
㫮 四
兄海
角之
也肉 
UNIVERSITY OF LOUISVILLE

A BRIEF SURVEY OF CHINESE IMMIGRANTS IN AMERICAN LIFE

\author{
A Dissertation \\ Subraitted to the Faculty \\ of the Graduate School of the University of Loulsville \\ In Partial Fulfiliment of the \\ Requirements for the Degree \\ of Master of Arts
}

Department of Soclology

By

Chwen Klang DJang

1938 
TO

My Wife

LILY CHOW DJANG

In appreciation of her

encouragement and devotion 


\section{ACKNOWLEDGEMENTS}

The author wishes to express his sincere appreciation to Dr. Robert I. Kutak, Head of the Department of Soclology, University of Loulsville, for his counsel and advise; to Dr. $\mathrm{J} . J$. Oppenhelmer, Dean of the College of Liberal Arts; to Dr. William C. Mallalieu, Professor of History, for reading and criticizing the thesis. The author is also gratefully indebted to Dr. Mary E. Burton, Professor of English, for valuable assistance in making the thesis conform to accepted standards of English usage; to Messrs. Harold G. Sanders and Franc1s H. Warden, of the Southern Baptist Theological Seminary, for critical reading of the manuscript. 
A BRIEF SURVEY OF CHINESE IMMIGRANTS IN AMERICAN LIFT 
TABLE OF CONTENTS

Chapter

Page

I. CHINA, YESTERDAY AND TODAY

The 0ld China, The New China; China's relations with the United States of America

II. THE HISTORICAI DEVELOPMENT OF CHINESE IMMIGRATION PROBIEH

Significance of Chineae Migration; The Lure of Gold; Early Popularity of the Chinese; Causes of Opposition to Chinese; Victims of Yob Law; Early State and Municipal Legislation Against Chinese; Early Treat1es; The Burlingame Treaty of 1868; The Exclusion Law of 1882; Summary of Treaties and Legislation and Their Administration; Treatment of Chinese Immigrants at the United States Immigration Stations; Conclusion

III. A BRIEF SURVEY OF CHINESE IMMIGRANT IIFE

Home Iife of Chinese Immigrants; Rise and Decrease of Chinese Population; Concentration of Chinese Immigrants; Physical and Mental Ability: Helght and Weight, Physical Strength, Health Conditions, Inteliligenoe, Ability to Use Fnglish Language, Personality Traits - Honesty and Trustworthiness, Crime and Delinquency; Occupation and Economic Status: Occupation Distribution, Changes in occupation Status, Unemployment, Financial Institutions, Relief Activities of Chinese Government, Decrease in Remittance of Overseas Chinese; Education: Educational Standard of First-Ceneration Chinese, Education of second-Ceneration Chinese, the Chinese Language Schools, Some Recomendations Regarding Acquisition of the Finglish and Chinese Language in the United states Public Schools; Press and Public Bodies; Religlous Affilation; Chinese Immigrants and National Relief

IV. SOME VITAL PROBLEMS AMONG CHINESE RESIDENTS IN AMERICA 
Racial Friction and Accomodation:

Factors that Cause Racial Prejudices, Some Specific Factors that Cause Raco Prejudice Against Chinese, Measurements of Attitudes Toward Chinese, How Race Prejudice May be Lessened; Occupational Opportunit1es: scarcity of 0ccupational Opportunities for Chinese Immigrants, Some Possible Solutions, the Heed of Vocational Guidance; Social Problems; Conflict of standards Between the Old and Younger Generation, Segregation in Social Relationshipe, Intermarriage; Problems of Education: Segregation of Chinese Pup11. In Public Schools, Exclusion of Chinose Pupila in Hisiseippl Delta; Moral Problema In Chinese Communit1es: The vice of Cambling The Curse of Oplum, Prostitution and Trade of Slave Girle, Tongs - Good and Bad - its Origin and Activities

v . CHINESE STUDENTS IN AMERICAN LIFE

History of Student Migration; The Boxer Indemity Fund and Its Relation to Chinese Students Coming to America; Surver of Forelgn Students in Colleges and Universities of the United States; Distribution of Chinese Students by States (in Localities), Distribution of Chinese Students by Courses (In Field of Studies), Chinese Courses offered by American Universities, Chinese on American Facult1es; Organized Efforts on Behalf of the Chinese Students: Chinese Student Association of North America, Chinese Students' Christian Association in North America, Chinese students' Association of the South, Chinese University Alumi Associat1ons, International student Committeo, Committee on Friendiy Relations Among Foreign Students; Chinese Students and National Crisis; Chinese Students in Amerlcan Iffe; Career and Influence of Returned studenta from America in China

VI. THE FUTURE OUTLOOK

Can the Chinese be Assimilated? The Conquest of Racial Prejudice; The Economle outlook; How Can the Social Workers Help? A Final Word 
FOREWORD 
FOREWORD

The interest of the writer in the subject of this thesis has grown out of a three yearg' sojourn as a Chinese student and traveler in the southern part of the United States of America, and through constant contact with the chinese Immigrants. Although there are not as many Chinese imigrants in the southern states as there are in the northern states, nevertheless it is significant to contrast their characteristics, their racial and economic problems, and their living conditions with those who are living in the northern states. As it is generally agreed that the problem of racial conflict is more intense and vital in the south than it is in the North, a study of the relationships and problems existing between the Chinese immigrants and the American people in the South has therefore recelved much consideration.

Since the onset of the world-wide economic depression Chinese immigrants in America have been in a state of unrest. Steps have been taken by many Americans to ban the Chinese merchants, while others have tried to employ native workers Instead of Chinese labor. China, not being a flghting power, is not able to extend protection to her emigrants abroad; they are left to shift for themselves, and, consequently, are subjected to discriminations almost everywhere. W1th the changing attitude and pollcy of the Unfted States government toward 1mmigrants since 1924, the oppressive regulations become more severe and the situation becomes more intense. 
Perhaps no other problem is so keenly debated and recelves so much deliberation as the present problem of unemployment. The Chinese Consulates in the different parts of the country have helped to return thousands of immigrants to china durIng recent years and many are making preparations to return in the future. In addition to the economic problems, there are the problems of racial conflict, soclal maladjustment, political discrimination, etc. To the solution of these problems this thesis attempts to offer some constructive contributions.

An attempt has been made to select descriptions of typ1cal case study situations. These have been drawn from the immigrants themselves in so far as this was possible, and secured from other sources, especially the United States Government documents, Chinese books, newspaper clippings, reports, and other published materials. In these illustrations the writer has tried to avold opinions, concentrating his attention upon the case study materials. These are used simply as the most feasible method of defining the attitudes of the Chinese Immigrants toward the United States Government and the American people.

It is but fair to state that some of the ideas expressed in this thesis would not have been possible had it not been for the ald given by Chinese immigrants, and by many of our fellow-students who are located in different parts of this country. The writer therefore wishes to acknowledge his indebtedness to the more than fifty Chinese 
immigrants, most of whom are laundrymen and restaurateurs, and to the many Chinese students of the different universities whose opinions and interests are reflected in the pages of this discussion.

$$
\text { C.K. DJang. }
$$

JuIJ $15,1938$.

Loulsville, Kentucky. 
Chapter I

CHINA, YESTERDAY AND TODAY
(1) The old China
(2) The New China
(3) China's Relations with the United States 


\section{Chapter I}

\section{CHINA, YESTERDAY AND TODAY}

Chine is the largest, the oldest and the most populous country in the world. When Abraham left Chaldean civilizat1on behind, 1,500 years before Chrlst, China's sages were already defining from tradition the principles that would become written social philosophy; in the centuries when the ancestors of the Europeans were barbariens, China had already a rich herltage, a glorious history, a high civilization, and a beautiful culture.

Nations have come and gone, but China goes on. China does not live by rice alone. China has not tried to live by things by which other nations have died: armies, power, brute force. China lives by spirit.

Dating from approximately 3,000 B.C., the Chinese have had as contemporar1es Egypt, Greece, Rome and many other empires of far-flung glory, who have ridden their proud steeds and conquered at the point of the sword but then have passed away to be remembered only as nations that were. But humble, simple, childike China has survived them all. What is the secret of this survival? The secret is not what materialistic science calls "the survival of the fittest." It certain-

1. Carver, W.0., The Course of Christian Missions, 1932, p. 175 
If cannot be the survival of the unfit. What is it? Let the question rest for a while.

I. The old China

One should think, however, of two Chinas, the ancient and the new. The old China began with the leader of the Shang Dynasty who gathered the scattered tribes into a united family long before the Chriatian era which marked the beginning of the western world. A simple division of Chinese history would define the first period as dating from 2852 B.C. to 206 B.C., during which time the ompire arose from an unorganized primitive culture of the prehistoric age to a consol1dated and well organized nation. This early perlod saw the change from a primitive form of living to a highly developed civilization. Many remains of this period, uncovered by archaeological surveys, have shown this age to be one of great development. China's philosophy began also within this period when the great leader of thought and life, Confuclus, was born in 550 B.C. He is recognized today as one of the world's greatest philosophers.

The second period, from 206 B.C. to 1644 A.D., Includes the eras of the famed dynasties of Han, Tang, Sung, Yuan and Ming. This period saw the first intercourse between China and Europe opened with the visit of Marco Polo to Kublal Khan's court and his return to Venice. Throughout these dynasties, there were five classes of soclety arranged in the

2. Shing, L.C., China Spoaks, 1938, p. 4 
following order: the men of letters, agriculturalists, laborers; tradesmen, and soldiers. It is interesting to note that tradesmen are second from the bottom and that soldiers were looked upon as lower than all of them. One may flgure out for himself the relationship of this fact to China's survival. Many Inventions were contributed to civilization in this period, notably those of porcelain, chinaware, paper, printing, compass and gunpowder. The arts, too, were of such high development that they have never jet been equaled.

The third period dates from 1644 to the present, during which time China continued under the rule of the Ching Dynasty for nearly three hundred years and then abruptly changed over night from a deapotic imperialism to a democracy.

\section{The New Chine}

The New China may be said to have its beginnings with the overthrow of the Ching (Manchu) Dynasty by Dr. Sun Yat Sen, the founder of the Chinese Repubilc; but the real awakening started from the year 1900 which witnessed the Boxer Rebel11on. That unhappy event started the swing away from antiquated methods and resulted in the adoption of western industriel1sm. Let us consider briefly the development of china along modern progressive lines:

In the field of education, the Chinese have always been considered a very literate people. However, the I1teracy was

3. Ib1d, p. 4

4. Ibid, p. 4 
among the select few only, whereas in modern Americen thought, a high degree of literacy means the education of the masses. In China, however, after the adoption of Mandarin as the nam tional dialect and the simplification of the chinese characters to 1000 basic and most common words, a mass education movement has been conducted during the past two decades. The results have been highly gratifying. In a report of the League of Nations' survey of Chinese educational activities, the statement was made that China, during the comparatively short period since the reformation of the system, has achieved a degree of progress beyond the demonstrated ability of most western nations. On the other hand, education is compulsory for children of grammar school age; and at the end of 1934, there were in 110 institutions of higher education in China over 47,000 students. In addition, thousands of students are studying in foreign lands. These are returning from their studies abroad and are aiding in the building of a new China.

Communication and transportation have also developed along progressive lines. There are radio stations of the latest type in all the large cities. Connection with the United States mainland is by direct radiophone and also by direct cables. Telephone and telegraph systems have been installed in all the provincial cities. The Chinese postal system has been highly commended by visiting foreigners. News need no longer be relayed by courler or by word of mouth

5. Report of Nat1onal Counc1l of Higher Education, Shangha1, China, $\overline{19} 3 \overline{5}$ 
into the far interiors.

Railroads in China prior to 1930 had been in a semineglected state of development. Transportation and communication are basic requirements of a modern industrialism, and as China has been rather slow, except during the last decade, In adopting western technique, its transportation facilities have also been quite behind the times. But since 1930, great atrides in all forms of transportation have been made. According to the report of the Economic Councll of the NatIonal1st Government at Nanking, railroad construction has almost doubled the facilities existing prior to 1930. The connecting link in the Canton-Hankow railroad was completed In 1936, and thus China is traversed by rail from north to south. Purchases of railroad materials have increased sharply in the last five years. The United States is an Important source of equipment.

Highway construction has shown even greater advances than rallroads because of 1ts larger necessity and also because of its smaller capital requirements. Nearly all the provinces are interconnected by paved highways and the motor bus and truck are now common sights in the far interior regions. There were at least 100,000 miles of improved roads at the end of 1936, and the program for road construction was gathering momentum.

The latest method of modern transportation, aviation, has had a rapid and admirable growth in China. It was only natural that aviation, once adopted in China, should grow 
rapidly. The great distances between important cities and remote interior regions created a demand for rapid transportation in keeping with the modern tempo. Thus a network of almays was developed mainly with government cooperation and investment by forelgn groups. America has alded greatiy in the growth of aviation in China. The Pan-American Airways has spanned the Pacific Ocean, thereby giving China direct air contact with the mainland of the United States. The training of both civilian and military Chinese pilots has been conducted under American leadership and many of the Chinese aviators have recelved their training in the United States.

To show what aviation means to China, only a few examples need be cited of the accessibility of interlor cities by a1r. Chungking, in Szechuan Province, is 1,600 miles up the Yangtze River from Shanghal; to reach it usually required more than a two weeks journey by steamboat, but now it can be reached in two days by plane. Chengtu was a three weoks journey from Shangha1, but now by a regular a1r schedule one makes the trip in three days. All the coastal cities are connected by a1r. In 1936, contracts were entered that would enable a passenger to go completely by air to Europe via a Southern Asla route by way of India. Also a route connecting with Russia has been in advanced stages of development.

In the fleld of agriculture there has been made slow but definite progress in the adoption of western techniques. Exm perimental farms have been established and institutions of higher learning have conducted scientific research for the 
benefit of agriculture. An increasing number of students of agricultural chemistry and other phases of farming, and the active encouragement given by the national government have effected great advances in crop production. Thus in 1935 China led the wheat crop production of the world. She has always been among the largest producers of cotton, rice, tea and soybeans.

In the industrial fields also, China has made rapid advances recently. For example, in 1902 there were only 17 cotton mills in Shangha1; in 1922 there were 116 mills w1th 1,000,000 spindles. In 1932 there were over 44,000,000 spindles operating in 128 plants representing investments of $\$ 450,000,000$. In the statist1cs of forelgn trade, there 1s an indication of the progress of its industrial growth. As domestic production is not yet enough for domestic consumption, the principal imports (as 1llustrated by trade with the United states) are made up of machinery, metal products, rallroad materials, airplanes, autos and trucks, raw cotton, paper and wood products, chemicals, cereals and flour. In return, China exports to America principaliy tung 011, raw s1lk, tea, eggs and egg products, furs and skins, bristles, tungsten and antimony. These items are entirely complementary and non-competitive.

Polltically speaking, China has made great progress in the reformation of the government. Confronted with many inherent obstacles such as language, adherence to ant1quity, lack of political consciousness due to traditional la1ssez- 
faire rule during the empire, the adoption of a republican form of government over night was beset with many difficulties. During the quartier century of 1ts republicanism, China has had to face the World War problem, a struggle against Communism, floods and famines and forelgn aggression. Progress has been made and now China has developed a national unity and a national political thought. The government is nominally a democracy, but as yet it is being conducted through the bureaucracy of a party government. At the last Kuomingtang Plenary Session, a national constitution was drafted and the initiation of national suffrage was contemplated. Th1s is belng made possible with the achievement of mass education and the training of civic leadership. A new spirit is being shown by the people in a national unity.

other achievements of the national government in the last few years have been the amelioration of peasant conditions, construction of highways and rallroads, improvement of public works, the fostering of industrial growth; and, last but not least, the standardization of the currency system. Th1s last profect has been accomplished in face of difficulties such as the rise and decline in the price of silver upon which the former currency was based and also the detrimental activities of Japanese smuggling of silver. The adoption of a currency system of national bank-notes was effected by the nationalization of silver and the managing of foreign exchange. Since the inception of foreign exchange control, the rate of exchange with the principal nations has 
shown the highest stability. There is no doubt that a stable currency is a requisite for prosperous commerce and the industrial and commercial progress of the past few years is a witness to the success of China's currency reform. Indeed, modern China is quite different from old China. Its industrial and political awakening shows the capacity of the Chinese people for progress. In 1ts adoption of western industrialism, China has not forgotten the valuable training of her ancient clvilization but has amalgamated the best of the East and the West. China's record as a re-born nation is one of which to be proud. She has cooperated fully, according to her ability, in the promotion of international accord and friendship. She has maintained a high regard for international treaties and China's integrity as a nation is show by her adherence to the League of Nations' Covenant in spite of adversity. Although the recent Japanese invasion has disrupted her normal peaceful progress, China has proved that she can and will continue to contribute to world clvilization and world amity. The culture of her people is a commendable one.

III. ChIna's Relations with the United States The United States of America should have a deep and abliding interest in China. The two countries are in the same latitude - It is the latitude from which the rulers of the world have come. The two countries have wlde coast ranges. Both are predominantly agricultural and independent; both possess vast manpower and gather around great central 
river systems.

There are at present 85,000 Chinese in America who have American investments amounting to over $\$ 100,000,000$. They send annualiy $\$ 25,000,000$ back to China. There are 12,000 Americans in China of whom 6,000 are missionaries or persons connected with American business welfare and educational work. Over $\$ 60,000,000$ of American money has been Invested In schools, hospitals, and missionary enterprises in China. This is more than the rest of the world has done in China. Americans in China have their social clubs, civic clubs, churches, educational clubs, and chambers of commerco. Ten of the leading cit1es of China have American Chambers of Commerce. There are more forelgn students in American universities from China than from any other country in the world. Of the 650 Chinese listed in Who's Who in China in 1932, 158 have recelved education in America, 102 in Japan, 36 in England, 21 in France, 12 in Germany, 3 each in Rusila and Switzerland, and 2 in Belgium.

The most amicable relationships have continued between the United States and China since the first treaty in 1844. The one American act of restoring the Boxer Indemnity Fund of $\$ 25,000,000$ for the education of Chinese students did more to cement this friendly relationship than any other one thing. Closer relationships were formed when the United

6. Dodd, M.E., Girdling the Globe For God, 1935, p. 113

7. Kwe1, C.S., The Chinese Year Book, 1935-36, pp. 429-45 
States became an Aslatic power by entering the Philippines In 1898; and again, when the trans-Pacific alrways were completed in 1934. Cordial relationships were further strengthened when the United States was the first world powor to recognize the Chinese Republic in 1911. As a result of these amicable relationships, the United States ma1l to China has increased within fifteen years from one thousand packages per month to over flve thousand. The United States' trade with China has Increased 270 per cent whlle the German trade has increased only 36 per cent and the trade of Great Britain has fallen off 33 per cent during the past fifteen 8 years.

There are some interesting and striking contrasts between the United States of America and China. The population of the United States is $125,000,000$ and that of China 1s $466,000,000$. America's population is 30 persons to the square mile and China's is 280 to the square mile (average). Central China, the region from which the writer comes, has 850 people per square mile. 10

The average farm in the United States has 80 acres, but in China it has two to five acres. Two and one-half per cent of the Chinese farms are occupled by graves, since the

8. These flgures are based on the census estimates of Chinese Post office, 1934

9. United States Census, 1930

10. These figures are a summarization of the facts collected by the Statistical Bureau of the National Christian Counc1l, Shangha1, China, 1933 
Chinese bury the1r dead almost anywhere in the open flelds. Amerlca has nearly 30,000 newspapers while China has less than 200 dallies. America has one copy of a newspaper to every three persons while China has only one for every 550 11 persons.

Ra1lway mileage in America exceeds 250,000 miles while it is only about 11,000 miles in China. The first railroad built in China in 1876 at a distance of eleven miles out of Shanghal had to be torn up on account of the superstition of the people. The Texas of China, the Szechwan Province, with a population of $50,000,000$, has not a single mile of 12 ra1lway.

But although China is far behind in materialistic civ111zation as compared with the United States of America, she is endowed with wonderful possibilities. She abounds in mineral resources; gold, sllver, Iron, zinc, and 011 , and none of these has been fully developed. She has already given to the world much of 1ts silver. She has great manpower. Already she has the largest standing army in the world, consisting of three and one-half million men. All schools are required to incorporate military training. Indeed, Japan has forced her way into China at the point of the sword; but when China becomes universaliy educated, her resources fully developed, and her people become thoroughily

11. Ib1d

12. Ib1d 
united and militarized, with an army of $50,000,000$ men, Japan one day will wake up to discover that the force by which she conquered has become the means of her own self-destruction. The one outstanding feature in the present situation in China is undoubtedly the fact that the country is undergoing fundamental transformation. The proverbially conservative, slow-moving Chinaman is going through a great change. He is changing visibly, rapidiy, and radically! There never has been a time in the history of China's national development when changes were taking place on such a great scale, in so many directions, and at such a rate of speed as they are now taking place. The great national movements which are sweepIng over the length and breadth of the country are but the outward indications of the deeper changes which are going on In the minds and hearts of the Chinese people. The estab11shment of the New Nationalist Government marks the triumph and acceptance of a new political theory, and the moving of the national capital from its traditional seat in Pelping to the new site in Nanking is a manifestation of an inward determination to break with the past. The adoption of a new flag is the signal for the nation to start anew. Indeed, China, educated, united, developed, with its vast population, natural resources and native ingenuity, will become the world's mightlest power in the coming generation. 


\section{Chapter II}

THE HISTORICAI DEVELOPMENT OF THE CHINESE IMMIGRATION PROBIEM

(1) Significance of Chinese Migration

(2) The Lure of Gold

(3) Early Popularity of the Chinese

(4) Causes of Opposition to Chinese

(5) Victims of Mob Law

(6) Early State and Municipal Logislation Against Chinese

(7) Early Treaties

(8) The Burlingame Treaty of 1868

(9) The Exclusion Law, 1882

(10) Summary of Treaties and Legislation and Their Administration

(11) Treatment of Chinese Immigrants at United States Imigration Stations

(12) Conclusion 
Chapter II

THE HISTORICAL DEVELOPMENT OF THE CHINESE IMMIGRATION PROBLEM

Although China is primarily an agricultural country, her trade with forelgn countries has been going on for centuries and Chinese omigrants have sottled in all parts of the world to the number of tens of millions. According to historical records, Chinese communications with the countries abroad began in the Ninth Year of Yen-Ho1 of Han Huan T1, approximately 100 B.C., when a special envoy was sent by Homperor Anton of Ta Chin (according to modern scholars, Ta Tsin refors to Rome). The navigable route to the East was then first discovered. 1

In the time of Han PIng T1, India also sent an envoy to China, and thus began the communication between India and Ch1na. After Buddhism had spread eastward, many Chinese monks traveled to India through the South Seas during the time of the Taing, We1, Sul, and especially during the Tang Dynasties. In the Ming Dynasty, Chen Ho salled down the "Western Ocean" seven times, a fact which marked a great triumph in vojages abroad. Then it was that the foundation of Chinese emigration was la1d.

1. Kwe1, Chung-shu, The Chinese Year Book, 1935-36, p. 430

2. Ib1d, p. 430 
The causes of chinese emigration had been twofold:

overpopulation w1th the consequent economlc distress; (2) Political oppression. The Chinese emlgrants to the South Seas in the past were mostly political refugees. The movements occurred chlefiy on three occasions. The first group sa1led south becanse of the great chaos created by the notor1ous robber chief, Huang chao (黄臬). The second group of emigrants went out because of the barbarian invasions which finally terminated the dynasty of sung about 600 A.D. The loyal subjects of sung who were unwilling to live under alien mule took refuge in Indo-China, Dfamb1, (占城), Cambodia, and M. Sawng Klara of Siam. The third group of emlgrants departed because of the Manchu conquest of China and the defeat of Kwe1 Wong in Burma; as a result many Chinese soldiers and c1tizens settled in Siam and Burma. Koxinga also started an unsuccessful revolution in Formosa; consequently, many Chinese soldiers and citizens settled in Formosa and the Philippine Islands.

During the last days of the Manchus, mistreatment on the part of the government and economic depression made the Chinese turn their eyes abroad again; hundreds and thousands of them came to North and South America for trade and industry. The conventence of modern communication further accelerated Chinese emigration.

While accurate statistics of the Chinese emigration to all parts of the world are almost non-existent, the following 
Incomplete records of Chinese immigration into countries of the western hemisphere are interesting.

Mexico from 1909 to 1924 recorded 27,950 Chinese arrivals, but the fact that in 1922 there were only 3,000 Chinese in the country indicates that this movement was temporary. In 1847 some 800 Chinese came to Cuba under contract. By 1862 there were over 60,000 Chinese on the Island; by 1922 some 90,000 . Of recent jears few Chinese have entered Bra211, the number residing there in 1922 being only about 20,000. In 1857 there were 450 departures for Peru and in 1872 as many as 13,809 . At present 45,000 Ch1nese appear 3 to be residing there.

Overseas the Chinese are scattered almost everywhere. The total number has been variousiy estimated as from $10,000,000$ to $12,000,000$. A careful investigation by the Chinese National Overseas Affairs Commission made in 1836 from the reports of the chinese consulates abroad shows the grand total of overseas Chinese as 7,900,000. They are distributed as follows:

3. Davis, M.R., World Immigration, 1936, p. 309

4. Kwe1, C.S., op. c1t. p. 446 TStatistics furnished by Chinese Nationalist Government) 


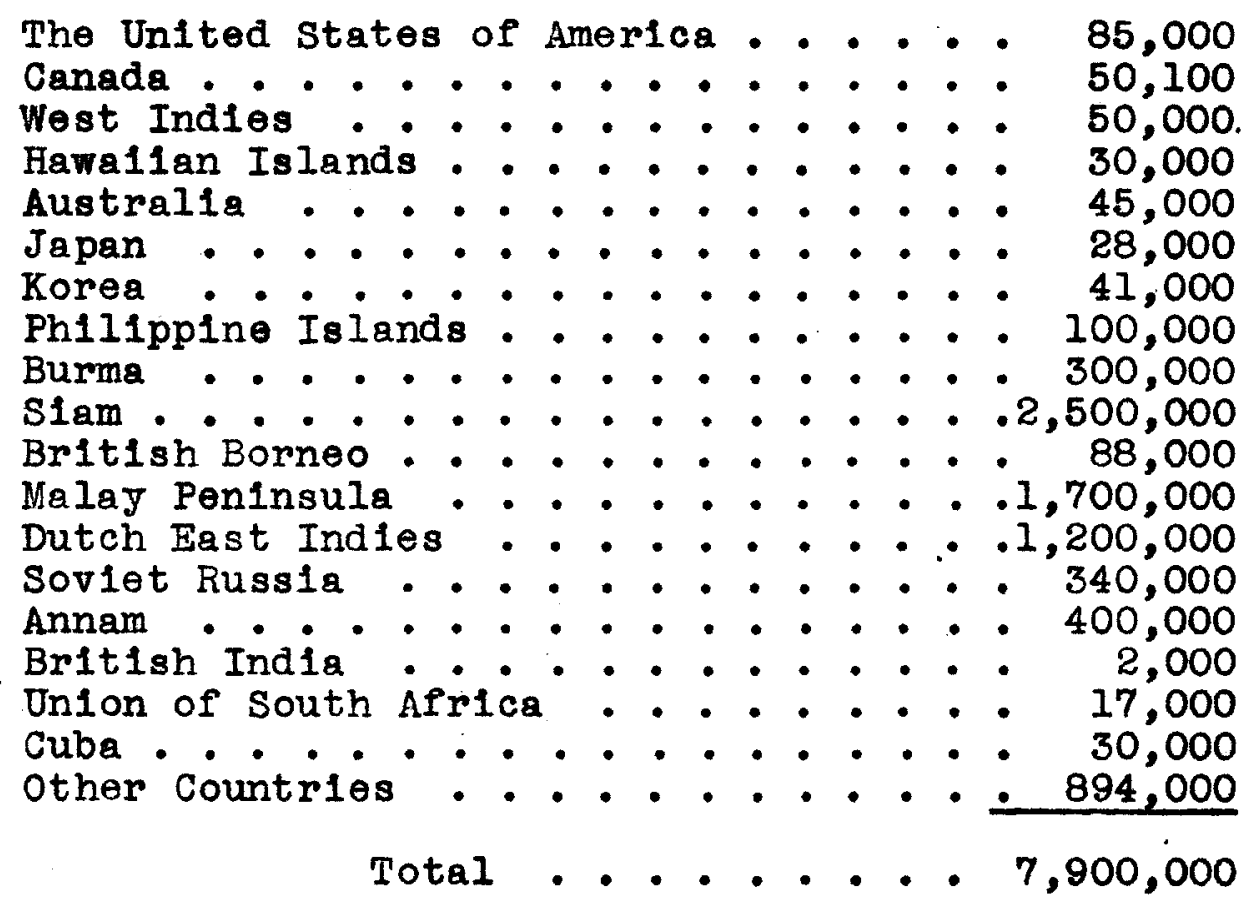

Thus the chinese emigrants have settled everywhere in the world. They are to be found as far north as S1beria, as far south as New Zealand and as far west as the west coast of the United States. But it is in the South Seas that the peaceful penetration of the Chinese has been most successful, as may be seen from the foregoing statistics. Nearly. seventy-five per cent of the Chinese settlers abroad are concentrated in the lands bordering on the South Seas.

II. The Iure of Gold

The Chinese first appeared in the immigration statistics of the United States government in 1820 when one Chinese was admitted. From 1820 to 1853 only forty-two Chinese came to this country. There are many tales regarding the first Chinese settler in San Francisco; such as the cabin-boy of Simon Bolivar who landed there in 1838; a merchant, named Chum Ming, reported to have arrived in 1847; and of the Ch1- 
nese woman servant who came in 1848 aboard the b1g "Eagle" with her employers.

The real beginning of Chinese immigration occurred in the spring of 1848 when the discovery of gold in California was made known and the great rush followed in search for gold. The city of San Francisco is st1ll known today to the Chinese as the "Old Gold Mountain" (嚄金山). The movement Increased each year unt11 1882 when 39,579 were admitted the largest number ever to arrive in a single jear.

Practically all the emigration from China has been from densely populated districts in the vicinity of Canton where economic conditions have been very hard. These Cantonese used a dialect not understood by a very large part of the Chinese people. Although they were underprivileged econom1cally and educationally, they have made much progress abroad because of their independent and progressive spirit and their physical endurance. From this region in the extreme south of China have come most of the elght millions of Chinese who have migrated to almost every part of the world.

By 1852 1t was estimated that only about one hundred Chinese had arrived in California. In 1854 the number was 13,100. From then on the annual rate varied between three and five thousand. In 1859 the number of arrivals leaped to

5. Shepherd, Charles R., The Ways of Ah Sing, 1923, p. 197

6. Annual Report of the Commisioner General of Immigration, 1919, pp. 53-54

7. Huie Kin, Reminiscences, 1932, pp. 116-117 
12,874, and in 1870 to 15,740 . Then for two years it dropped to 7,000 , but reached the high peaks of 20,000 in 1873, 22,781 in 1876 and 39,579 in 1882. However, many returned to China from year to year. The Unfted States Census of 1930 records the total number of Chinese in continental United 9 States as follows:

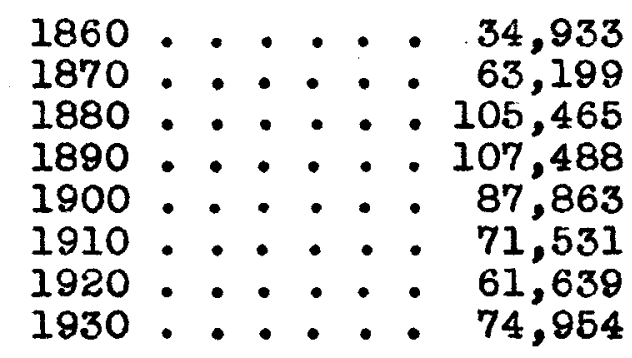

The continual increase of the nativemborn should, however, be noted. For example, in 1930 figures show forty-one per cent of the Chinese are American-born, so that the forelgn-born Chinese in the United States today are only 44,086.

\section{Early Popularity of the Chinese}

From the earliest days of the American settlement of California, Chinese laborers were recelved without prefudice and even with enthusiasm. They were honest, peaceful and Industrious laborers; and the form of organization of the Chinese laborers, by which it was possible for employers to secure the services of almost any number desired through the contractor, placed a premium upon their employment. Although mostly agriculturalists at home, they adapted themselves to

8. Bancroft, H.H., H1story of Cal1forn18, Vol. XXIV, 1890, p. 336

8. United States Census of 1930, Vol. II 
the new country and became not only miners but also laborers in many flelds. San Francisco used to send 1ts laundry as 10

far as Hawall to be washed; cooks were scarce and housemaids unobtainable in mining camp days, for this was a man's civilization and women were very few.

The Chinese bad no prefudice against doing "women's work"; consequently, they started laundries, became cooks and housemaids, even taking care of bables, and generally subst1tuted for women workers - so much so that when it was first suggested that they be employed in railroad building, serlous doubt was actually expressed as to whether they were strong enough for such hard labor. They proved their mascuIine hardihood, however, and did a lion's share of the hardest work involved in completing the first great transcont1nental railroad in 1869.

Before long the "China Bojs," as they were then dubbed, were being approached by zealous Christian gentlemen and orders were sent back to China for Scriptures and Christian tracts with which these immigrants might be converted and edified. When these printed materials arrived, there was a celebration and three hundred "China Boys" arrived for the ceremony. These were the days when the Chinese were looked upon with favor and with "patronizing indulgence." They were welcomed in the states with open arms, with the blessing of the law and press. But, of course, this attitude did not

10. Jones, "Cathay on the Coast," American Mercury, No. 8, 1926

11. Testimony of Charles Crocker in 1877, United States Senate Report, No. 689 
last very long.

IV. Causes of Opposition to Chinese

Soon difficulties arose and objections were raised when they came into California in large numbers. The sentiment was aroused primarily by the economic fear of competition from efficient labor with a lower standard of living. Since the Chinese were willing to work for lower wages and possessed greater physical endurance, the white laboring men feared that the chinese would underbid them in any field they chose to enter. If given unlimited privileges of immigration which steamship companies and capitalistic employers were systematically encouraging, Chinese labor certainly was in a position to drive the white working men from the entire $\mathrm{Pa}-$ cific Coast. It was, therefore, a genuine and by no means entirely imaginary fear that rallied the working classes behind the slogan: "The Chinese must go." "We are ruined by Chinese cheap labor" ran a Iine in Bret Harte's familiar poem, "The Heathen Chinese," published in 1870. It was the instinct of economic self-preservation by a working cless which was not at all squeamish as to its methods of securing results and which was led by Irish agitators who used tried and tested mob psychology.

But there were more than economic factors involved. The peculiarities of the Chinese racial and physical characterist1cs - the dress, color, language, habits, - and the inoffensive manners and general defenselessness of the Chinese also 
helped to develop racial antipathy. Professor Robert E. Park, of the University of Chicago, said that the Chinese had pecullar characterist1cs which made for "high visibility." The earlier Chinese, under the rule of the Manchu Dynasty, had a very peculiar appearance caused by the wearing of the queue a long braid of halr down the back, loose pajama-like clothes with baggy-seated trousers and, when working in the fields, great flat circular bamboo hats - now much prized as workbaskets or wall decorations by American women. People of other nations more or less merged into the American scene and blended with the inhabitants. But not the chinese. He is unmistakably Aslatic and different - and there 1s little hope for him to be assimilated.

The whole situation was further complicated by the revulsion against certain types of vice and crime, such as gambling, oplum smoking, and prost1tution, which were undoubtedIy greatly exaggerated in popular opinion. All these unfavorable aspects of Chinese life have caused a widespread sentiment on the Pacific Coast in favor of Chinese exclusion. Consequently as early as 1852, the governor of Callfornie advised that Chinese coolie immigration be restricted and that Congress be urged to prohibit coolie labor in mines, giving as his arguments that the Chinese were unassimilable, that they lowered the standards of living of labor, that they came here merely for money which they would take out of the country, and that unless checked they would soon be coming in such overwhelming numbers as to endanger the public 
tranquility and injure the interests of the people.

In 1879 California incorporated into her constitution these words: "The presence of forelgners who may not become citizens of the United States is dangerous to the well-belng of the state, and the legislature shall discourage the immigration of all such allens by all means within its power." The exclusion movement was first started in the mines, where American miners objected to forelgn competition - European, Mexican, Chilean, and especially Chinese. Of ali the groups involved, the Chinese were the most clannish and obvlously allen; consequently, Chinese suffered mob violence in some mining districts. Centuries of social adjustment in an over-crowded country had taught them the value of ylelding without a struggle. Laundry work was a non-competitive occupation, and so, in 1870, out of 2,069 laundry-men in San Franc1sco, 1,333 were Chinese. Cooking and household service also welcomed them and led them naturaliy into the restaurant business. Their agricultural background made it easy for them to take up vegetable gardening. The vegetables had to be sold, so they became peddlers, going about (at first) with two enormous round-cornered baskèts holding several bushels and carried at the ends of a pole balanced over the shoulder.

V. V1ctims of Mob Law

12. Journal of the Senate, 3rd session, 1852, pp. 669-675

13. Bancroft, H.H., History of California, Vol. XXIV, $1890, p .210$

14. United States Census of 1870, Vol. I 
But in spite of their effort to find marginel and noncompetitive occupations, the Chinese Inevitably came in contact with the white workers in some occupations, and the tragic results were that many Chinese were imposed upon, exploited, cheated, mobbed and massacred.

In 1855, for example, thirty-two Chinese were murdered In California - which heppened to be the exact number of American missionaries slain during the Boxer Uprising. In 1862, this number was increased to elghty-e1ght. It may be sald that only once did the United States pay an Indemnity for any of these losses, and this was offered as an act of grace and not of right when $\$ 147,748.74$ was paid on account of the massacre at Rock Springs, Wyoming, in 1884, where in one evening twenty-elght Chinese were murdered, many were wounded, hundreds were driven from their homes and property worth that amount was destroyed. 15 When we remember the heavy indemities exacted from eastern countries for attacks upon forelgners, notably the Boxer Indemnity in China, we can understand the effect which these one-sided standards had upon Chinese officials. The United States was able to reply in every case that the individual state was responsible for disorders within Its limits - and China could only reply that she had no dealings with stetes, but only with

15. McKenzie, R.D., Oriental Exclusion, 1927, p. 29 There had been other attacks; for exemple the Los Angeles massacre occurred in 1871, when 22 Chinese were hanged by a mob following the death of one officer and the wounding of two others who had attempted to break up a tong war. See R.G. Cleland, A History of California, The American Period, 1922, p. 418 
the United States.

The situation became especially acute in periods of economic depression and social unrest. One such crisis in California occurred in 1870-71 just after the completion of the trans-continental raliroad which brought a great increase of white immigration at a time when many Chinese who had been bullding the rallroad were thrown out of work. Another and more serlous crisis began in 1876, when the effects of "the panic of 1873" really reached the Pacific Coast. The decade from 1876-1886 was one of general soc1al unrest in California. The working man's party and the "Knights of Labor" arose, the new constitution of 1879 was adopted, "sand-lot" ag1tators like Dennis Kearney ralsed the slogan, "the Chinese must go." So the Chinese were subjected to riots, expulsions and even lynching in many places through the west - notably at Rock Springs, Wyoming, at Tacoma and Seattle, Washington, at Log Cabin, Oregon, and elsewhere. Naturaliy non-resistant, and without any strong government to protest effectively in their behalf, the mildmannered sons of the Middle KIngdom were helpless before an epidemic of mob violence.

Dr. Palmer in his book, Orientals in American Life, gives a very vivid picture of the mob violence which struck one of the small c1t1es (Snohomish) of the Northwest as fol-

16. Treat, Payson J., The Far East, 1937, p. 523 
lows:

"During the year 1886 there was much agitation against the Chinese. The newly organized Knights of Labor sponsored this movement to a large extent and it became the 'burning 1ssue.' Snohomish caught the contagion, though there were but few Chinese in the viliage. An anonymous call for a mass meeting was issued and the gathering was held at the Masonic Hall. A promInent citizen presided, but before the close of the meeting he announced himself as against any action. Possibly on account of the stand taken by the chalrman, nothing was done. A second meeting was held, addressed by another speaker, and a committer was appointed to inform the Chinese that they must go. This committee refused to act, however, and the matter rested in abeyance for some weoks. At Seattle and other cities, however, the crusade against the Chinese rose to greater heights and early in February the Chinese were quietly told that they were not wanted in Snohomish. With Oriental fatalism they bowed to the inevitable, and, with but a few exceptions, they either sold or removed their goods and eighteen of them took boat down the river on the steamer Cascade.

"The crisis was undoubtedly brought about by the serious rioting in seattie to quell which the troops were called out. There remalned in Snohomish but three Orientals, who owned a laundry business which they hoped to sell, and had agreed to go on the following Monday. All would have been well had not the excitement of the Seattle troubles so stirred popular feeling that some misguided men placed explosives under the loundry, completely wrecking it. No one was injured and the episode would probably have been pessed over lightiy had the issue not been sharply drawn all over the West. Under the circumstances it was made much of and several men were indicted for conspiracy, but, as in the other cases for participation in this Chinese expulsion, they were not convicted. But the majority of the citizens, while opposed to the coolie labor in America, did not approve the unnecessary violence used."

17. Palmer, A.W., Orientals in American Life, 1934, p. 16 
Not all communities were so considerate as Snohomish.

In Tacoma a mob took posisession of Chinatown. What took

place there is thus described by a Chinese author, Mr. Wu

Ching Chao in his manuscript, Chinatowns:

"They had a number of wagons with them and, as soon as the houses of the Chinese were reached, their goods were thrown into them while their owners were assembled in their nelghborhood to be marched out of town. The day was cold and rainy. The Ch1namen were greatly exclted but none of them offered any resistance. An equal number of children could hardly have been managed more easily. Several of them were old and decrepit; a few were sick, but these were forced out of such shelter as they had and placed on the wagons with their goods... . The evicted Celestials, escorted by their tormentors took up their line of march through the town and out along Centre Street to Lake View where the wagons were unceremoniously unloaded and the owners of such goods as they contained left on the bleak prairie to make themselves as comfortable as they could unt1l the following dey, and it was reported that two of the sick died meantime from exposure."

Here is a document from San Francisco, dated May 13, 19

1876:

"Sir: I am instructed by a resolution of the Central Ant1-Coolie Club of the Eleventh Ward to notify you that, unless you discharge all the Chinese now in your employ in one week from date hereof, your name will be placed on the blacklist of this club and published in the daily press of this city. All members of the Anti-Coolie clubs of this city are prohibited from or in any manner whatever patronizing any firm or company, factory or persons employing Chinese labor."

18. Wu, Ching Chao, Chinatowne, 1925, p. 375 An unpublished doctor's dissertation at the University of Chicago 19. Un1ted States Senate Report, 1877, No. 689 
VI. Early State and Municipal Legislation Against Chinese This popular feeling against the Chinese soon expressed itself in state legislation and city ordinances, directed specifically or indirectiy against him. "An Act of the Californian legislature in 1855 imposed a head tax of fiftyfive dollars on every Chinese immigrant arrival. In 1858, a subsequent act prohibited all persons of the Chinese or Mongollan races from entering the state or landing at any port thereof, unless driven on shore by stress of weather or unavoldable accident, in which case they should inmediately be re-shipped." In 1862 another act was passed providing that every Mongolian over elghteen jears of age should pay a monthly capitation tax of two dollars and a half (\$2.50), except those engaged in production and manufacture of sugar, rice, coffee and tea.

In like manner a number of city ordinances were passed for the purpose of reaching the Chinese indirectly. The San Francisco city government passed a laundry ordinance imposing a Ilcense fee of fifteen dollars (\$15.00) per quarter on laundries not using a vehicle, and vegetable peddlers were required to pay a fee of two dollars $(\$ 2.00)$ if they drove a wagon, of ten doliars $(\$ 10.00)$ if they went on foot. The "queue ordinance" provided that every person convicted for any criminal offense should have his hair cut to a length of

20. Smith, R.M., Emigration and Immigration, 1931, p. 238 21. Annual Report of the Commissioner-general of Immigration, 1919, pp. 53-54 
one inch from his head. This was done because the 108 of his queue was a lasting disgrace to the Chinaman. The "cuble air ordinance" required that no person should let or hire any tenement house where the capacity of the rooms was less than five hundred cub1c feet for every person sleeping there which was enforced only against the chinese.

But all these restrictive state laws were held to be ineffective by the California Supreme Court and finally in 1876 were declared unconstitutional by the Federal Courts. The issue therefore became a federal one and an appeal was made by the State of California to Congress for national legislation to put a stop to Chinese immigration.

\section{Early Treaties}

In order to summarize the legislative history of Chinese exclusion, a study of the early contacts between the United States and China will be profitable. The Amerlcan colonies were almost unknown to China during the Revolutionary Var. Not one Chinese in a million had probably ever heard of them. The first contact was made by an ex-artillery officer in the United States Army, Major Samual Shaw, who went to Canton in 1786 and later served in the capacity of merchants' consul unt11 1794. Shaw inaugurated two pollcies which have served 28 a basis for America's relation with China: namely, cooperation and most favored nation treatment. ${ }^{23}$ During the peri-

22. 'Smith, R.M., op. c1t., 1931, p. 240

23. American Fore1gn Relations, published by the Counc1l on Foreign Relations, 1930, p. 8 
od of 1786-1844 the United States had no polit1cal relationship with China and was only represented by merchants' consuls who depended on trade for income. About half of the time, there was no representation at all. Many Chinese, however, became friends of American traders and placed a great trust in them due to the fact that Americans were not supported in the Far East by naval vessels as were the British. They had to depend on Chinese favor which they undertook to cultivate. The Chinese often went to great lengths in explaining the differences between the Americans and the EngI1sh - they preferred the Americans to the British. This principle still holds today.

The polftical relations between the Unfted States and China began in 1844 when Caleb Cushing arrived at Macao to negotlate treaty following the Oplum War. His negotiations were based on four principles which have played an important part in formulating American policy toward China: namely

(1) National equality,

(2) Extra-territorlal privileges,

(3) Most favored nation treatment, 25

(4) Maintenance of China's independence.

In 1858, a new treaty was negotiated, known as the Reed Treaty, providing. for non-molestation of missionarles in the interior of China, and for the right of forelgn diplomats to reside in Peking and freedom to travel through the country.

24. Hoffman, W.G., Pac1f1c Relations, 1936, p. 414

25. M1ller, Hunter, Treatles and Other International Acts of the United States of Amer1ca, Vo1. IV, 1934, Document 109, pp. 559-662 
But neither of these two treaties said anything about the rights of Chinese trading or residing in the United States. Under the United States laws at that time they were allowed to come and go freely, to engage in any occupation they pleased, and if they committed crimes they were subject to the jurisdiction of the United states courts. In other words, the Chinese during those days were coming to the United states under exactly the same conditions as the c1t1zens of any other nation and enfoyed exactly the same priv1leges.

VIII. The Burlingame Treaty of 1868

The appointment by President Iincoln of Anson Burlingame as American Minister to China in 1861 marked the beginning of the official negotiation between the United States and China on immigration problems.

The signing of the Burlingame Treaty, according to Mc 27

Kenzie, was largely due to the completion of the two great systems of transportation; namely, the Trans-continental Rallroad and the Pacific Mall Service, which aroused a spirit of optimism. Visionaries saw possibilities of tremendous trade between the. United states and China. Accordingly, an outburst of sentiment and consideration for the feelings of the Chinese paved the way for the signing of this treaty, which was concluded at Washington, July 28,1868 . The treaty

26. Gar1s, Roy I., Immigrant Restriction, 1927, p. 288 27. McKenz10, R.D., op. c1t., 1927, pp.26-27 
provided that the citizens and subjects of each country could move freely from one country to the other for the purpose of curlosity, of trade, or as permanent residents. The articles relating to the immigration problems are as follows:

"Article V. The high contracting parties Pormally recognize the inherent and inallenable right of man to change his home and alleglance and also the mutual advantage of the free migration and emigration of their citizens and subjects respectively from the one country to the other for purposes of curlosity, of trade, or as permanent residents, .... they therefore join in reprobating any other than an entirely voluntary emigration for these purposes'; and, consequently agree to pass laws making it a penal offense for a citizen of the Unfted States or a Chinese subject to take Chinese subjects elther to the United States or to any other forolgn country, or for a Chinese subject or a citizen of the United States to take any citizen of the United States to China or to any other foreign country without their free and voluntary consent, respectively.

- "Article VII. But nothing herein contained shall be held to confer naturalization upon c1tIzens of the United States in China, nor upon the subjects of China in the United States." 28

Burlingame was so successful that he was subsequently requested by the Chinese to represent them abroad. He accepted the invitation and, with a considerable retinue of Chinese officials, undertook a mission to the most important countries of the West in the interest of the Chinese. H1s labors, however, were cut short by death from pneumonia in St. Petersburg in 1870 and his pollcy was soon subjected to criticism by the increasing agitation against the Chinese on the Pacific Coast. 29

28. Garis, Roy L., op. c1t., 1927, p. 289

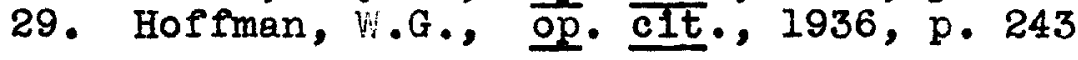


IX. The Exclusion Law, 1882

As a result of the violent anti-Chinese agitation, Congress was induced to investigate the matter in 1876-77. The California legislature sent a Memorial to Congress protesting against the Chinese and setting forth many charges. Among the assertione made were: that the Chinese were practically all coolles or labor slaves, that they were highly immoral and viclous; that they had secret tribunals which inflicted the death penalty without due process of the law, that they displaced native labor, that they could not be Christianized, thet they had no intention of remaining as permanent residents of the country and would not assimilate with the natives, that they sent money out of the country, etc.

The Memorial was a gross misrepresentation of the facts, but 1t expressed the feeling of many of the Americans of the Pacific coast at that time. The one who presented the matter before the Congressional Committee sald: "The Chinese are inferior to any race God ever made. These people have got the perfection of crimes of 4000 jears.. I believe the Chinese have no souls to save, and if they have, they are not worth saving." 31 .

As a further example of bis.s and of the unreasoning attitude of many Californians there is reported the following conversation between a native Californian and a French

30. Annual Report of the Commissioner of Immigration, 1919, pp. 53-54

31. Ibid, pp. 53-54 
tourist who inquired the reasons for the opposition to the Chinese:

"The Chinese are not productive."

"Why?"

"They make a lot of money and take it back to china."

"What else is the matter with them?"

"They won't become citizens."

"Why?"

"Because we won't let them."

"What else?"

"They are corrupt."

"How so?"

"They tried to influence the state Legislature not to pass the Exclusion B11l." 32

Congress, however, was influenced and biased by the CalIfornia Nemorial, and the investigating committee reported that Chinese immigration was wholly undesirable for the main reasons that the Chinese were vicious (which was not true) and that they competed with American labor (which was partialIy correct).

In 1879 Congress passed a bill limiting the number of Chinese who could come to the United States in any one vessel to fifteen, and repealed the favored-nation clause in the Burlingame Treaty of 1868, which provided for free immigration and emigration between the two nations. Fresident Hayes, however, vetoed the measure on the ground that it would have meant the violation of the Burlingame Treaty. Instead, a commission of three members, Messrs. Angel, Swift and Trescot, was sent to China to negotiate a treaty which would replace that of 1868 . 33

32. Mears, E.G., "Cal1fornia's Att1tude Toward the Oriental," Annals, American Academy of Political \& Social Science,

33. Treat, Fayson J., op. c1t., 1937, p. 524 
On October 1, 1880, the American commissioners laid before the Chinese commissioners, Nessrs. Pao Chun and II Hung Chao, a memorandum exhibiting the difficulty and dangers attending the free immigration of Chinese laborers into the United States and the desire of the United States to revise the treaty stipulations between the two countries on the sub34 ject.

The Chinese commissioners in a memorandum of october 7 , 1880, Intimated that they were ready to enter upon negotiations to prohibit the emigration of four classes: coolie laborers, criminals, prostitutes and diseased persons. They also pointed out that there was no compulsory emigration from China to the United States; that China rejoiced in the freedom which her subjects enjoyed in America. The American commissioners intimated that this proposal was insufficient and asked that the Chinese Govermment consent to such a modification of the free immigration clauses of the Burlingame Treaty as would avold the raising of questions that might disturb the friendly relations of the two countries. To this end the American commissioners submitted a project of a treaty which stated that the Government of the United states should have the right to regulate, limit, suspend or prohibit the coming of Chinese laborers, by which term was to be understood all immigration other than that for teaching, trade, travel, study and curlosity. The terms of the Treaty were

34. Garis, Roy L., op. c1t., 1927, p. 292 
agreed to on November 6,1880 , in which China gave to the United States the right to "regulate, limit or suspend" the Immigration of Chinese laborers but not "absolutely to prohibit 1t." Article I stated:

"Whenever in the opinion of the Government of the United States or their residence therein affects or threatens to affect the interests of that country, or to endanger the good order of the sald country or of any locality within the territory thereof, the Government of China agrees that the Government of the United States may regulate, limit or suspend such coming or residence, but may not absolutely prohibit 1t. The limitation or suspension shall be reasonable and shall apply only to Chinese who may go to the United States as laborers, other classes not being included in the limitations. Legislation taken in regard to Chinese laborers will be of such a character only as is necessary to enforce the regulation, limitation or suspension of immigration and immigrants shall not be subject to personal maltreatment or abuse." 36

After the Treaty of 1880 was concluded, Congress sought to take advantage of the new treaty's provisions and passed a bill to execute certain stipulations contained therein. However, on Apr11 4, 1882, President Arthur returned the bill with his veto; his principal reason for refusing to sign it being that the passage of such an act, prohibiting Chinese immigration for twenty years, was a practical violation of the treaty. But he approved an amended act fixing a ten-year term which might be considered only a suspension of immigration of Chinese laborers. No one believed that the gates would ever be opened to them again. It was generally 
realized that "suspension" really meant "permenent exclusion." Since that year, 1882, the exclusion of Chinese laborers therefore has been a national policy.

The next legislation on the subject was the Act of July 5, 1884, when another Immigration law was passed at a time of great stress with regard to the Chinese. In 1883, the Northern Pacific Rallway was completed. In 1885 the Canadian Pacific was finished. In both cases large numbers of Chinese laborers were thrown out of work. Lack of employment forced them into competition with white labor over a wide area. It was at this time that some of the most serious race rlots occurred (see section on "V1ctims of Mob Law"). The law amended several sections of the Act of 1882. For Instance, (1) that it is unlawful for Chinese laborers to come to the United States from any foreign port or place; (2) that the certificate of identity of a laborer, instead of being "prima facie" evidence, should be the only evidence permissible to establish his right of rementry; (3) that every Chinese person of the exempt classes, claiming a right to enter, should obtain the permission of and be identified as so entitled by the Chinese Government, or of such other forelgn Government of which at the time such Chinese person shall be a subject, and that the certificate thus required should be visaed by the American diplomatic representative in the forelgn country from which such certificate issues or by the American consular representation at the port or place 
of departure.

The Act of 1884 was carried out with extreme harshness and gave rise to a number of cases of individual hardship. Th1s law was renewed in force for ten jears by the Act of May 5, 1892, and was further continued in force by the Act of May 5, 1902 .

Opposition to the Chinese in the United States continued, so that in 1886, the Chinese Government informed the United States Minister at Peking that China of her own accord proposed to establish a system of strict and absolute prohibition of her laborers coming to the United States, and I1kewise to prohibit the return to the United States of any laborer who had at any time gone back to China "in order that Chinese laborers may gradually be reduced in number and the causes of danger averted and lives preserved." After some negotlations a treaty was concluded by Secretary Bayard and the Chinese Minister under date of March 12, 1888. The Treaty gave the United States the right to prohibit absolutely the immigration of laborers for twenty years, the only exception being that Chinese laborers who had returned to China might reenter the United States if they had there a lawful wife, chlld and parents or property or debts to the amount of one thousand dollars $(\$ 1,000)$. The treaty did not affect the right of the Chinese non-laborers - such as offin

38. "Nat1onal Or1gins," Outlook, May 5, 1926, Vol. V., 143:10 39. Reed, Dav1d A., Remarks In Senate, Apr11 9, 1924 
cials, merchants, travelers and students. They would be admitted on certificates issued by the Chinese Government and visaed by the American representatives at the port of departure. The treaty was sent to China for ratification in May, 1888, but was delayed due to the fact that the Chinese Government desired to lessen the term of twenty years and to gain for Chinese laborers having property less than one thousand dollars $(\$ 1,000)$ in value the right to return. The United States Congress grew impatient and passed the Act on September 13, 1888, without the ratification of the Chinese Government and much controversy followed as to whether the law could be enforced.

On October 1, 1888, President Cleveland signed a b111 making it unlawful for any Chinese leborer "who shall at any time heretofore have been, or who may now or hereafter be, a resident within the United States and who shall have departed, or shall depart therefrom, and shall not have returned before the passage of this Act, to return to or remain in the United States, and all certificates of identity under the Act of 1882 were declared to be vo1d and the issuance of such certificates in the future was forbidden."

The Chinese Government protested against this legislam tion, but with very little success. Finaliy, on December 8 , 1894, a treaty was signed at Washington in which it was

40. Parker, A. Warren, "The Quota Provisions of the Immigrant Act of $1924, " 1926$

41. Gar1s, Roy I., 오. 1t., 1927, p. 303 
agreed that for a period of ten years from the date of the exchange of ratification, the coming of Chinese laborers to the United States, except under the conditions specified in the treaty, should be "absolutely prohibited." Those going back to China were allowed to return to the United States providing they had a wife, child or parent or property worth one thousand dollars $(\$ 1,000)$ somewhere in the United States. On Jenuary 24, 1904, the ChInese Government gave not1ce of the termination of the Treaty of 1884 and refused to continue the Treaty after December 7, 1904. But the United States Congress, by the Act of April 27, 1904, omitted the reference to treaty obligations and enacted, "that all laws regulating, suspending or prohibiting the coming of chinese persons - - are hereby enacted, extended and continued without modification, limitation or condition." so the absolute prohibition of Chinese laborers was continued until 1924, when the Immigration law was passed which provided no quotas for races ineligible to naturalization (and the only eligible races are the white and the black). This has not only closed the door but slammed it shut. This act violated the treaty with China whereby the United States Government had agreed only to regulate, I1mit, or suspend such immigration. This arbitrary action by Congress, regardless of treaty rights and diplomatic procedure, created wide resent-

42. Ibid

43. United States Bureau of Immigration Hearings, 1925 
ment on the part of the Chinese. There has also been bitter criticlam of the way in which the law has been administered. Without any doubt the treatment accorded to the Chinese nationals was the principal cause of the boycott of American goods in South China in 1905, and 1t will always occasion resentment unt1l Chinese immigrants and travelers are treated exactly the same as Europeans.

X. Summary of Treaties and Legislation and Their Administration

(1) The Burlingame Treaty of 1868 reflects the early favorable attitude toward the Chinese brought about by the need for labor for rallroad construction and mental labor in mines.

(2) The Treaty of 1880 showed the growing opposition to the Chinese. It allowed the United States to regulate, limit, or suspend immigration temporarily and in a reasonable way.

(3) In 1882, the first of the Federal exclusion laws was passed. Additional legislation passed since 1882 has led to the adoption of a policy of complete and permanent exclusion of Chinese labor. The matter is thus no longer dependent chiefly on treaty regulation.

(4) For some time, both before and after the exclusion laws, stringent state laws were passed discriminating against the Chinese in numerous ways. Although most of these were declared to be unconstitutionsl, they reflect the bitterness and the political significance of the opposition to the Ch1- 
nese.

(5) Finaliy in 1924, the exclusion of immigrants ineligible to citizenship, although aimed at Japanese, formod a second line of defense against the Chinese as well.

Exclusion laws create problems of enforcement, interpretation and administration. Exclusion increases the desire to enter. Hence, "throughout the forty-five years of Chinese exclusion from the United States, there has been a continuous struggle on the part of the administrative officials to guard against 11 legal entry and to detect fraud among those applying for entry." Much annoyance to officials and often sertous hardship to the Chinese have resulted. Problems of administering the laws with respect to the entry of Chinese have included the following:

(1) The definition of classes exempted from exclusion has been difficult.

(2) Organized smuggling has been especially difficult to combat in the case of the Chinese.

(3) Genuine hardships were formerly produced by the fact that while domiclled Chinese merchants might legally bring in their alien wives, Chinese who were American citizens could not.

(4) Long delays and tedious hearings caused hardships and often meant that respectable chinese were detained for considerable periods in unsightly jails.

44. McKenzie, R.D., op. c1t., 1927, p. 16 Th1s book gives sufficient information on the administration of laws restricting the entry of Orientals in general. 
(5) The admission of foreign-born American cltizens of ChInese ancestry has at times produced an absurd situation. Whereas Amerlcanized allen Chlnese may never become cltizens, forelgn-born children of American citizens of Chinese ancestry, though entirely alien in culture and attitude, may enter and enfoy the privileges of citizenship.

(6) The Chinese exclusion laws heve resulted in the separation of famllies.

(7) The exclusion of alien wives of citizens is a serious bar to marriage of the Chinese with members of thelr own race.

(8) Both fraud on the part of some Chinese and hardship for many honest members of the race have resulted from difficulties in administering the provisions of the law which permits entry for temporary visits.

(9) Chinese students who have entered have experienced somewhat greater difficulties than have white students because of their ineligibility to citizenship.

(10) It has often been difficult for Chinese returning from temporary visits abroad to prove their former merchant status.

(11) There has been much resentment over the racial basis of exclusion 1tself. "It is hard for a high-class Chinese to see the logic of being excluded from the United States on the basis of color when Africans, Mexicans and Filipinos are free to enter. The discrimination has been further accentuated by the decision of the Supreme Court that 
even service in the United States overseas forces does not make possible the reward of citizenship, a reward which is given to other allens, white or colored." 45

In conclusion, there can be no doubt that some sort of adequate protection to save the Pacific Coast from an inundation of Asiatic labor was necessary. Unrestricted immigration would have been a kindness to no one - not even to the Chinese. But what a pity that it had to be done in such a crude and bungling manner! What a shame that sound diplomat1c procedures were so ruthlessly disregarded Would the United States have dealt thus with England, France, Germany or any other European power? It could have been done so much better. With patient, diplomatic approaches the cooperation of the Chinese Government might have been secured and a pollcy followed which considered and respected the sensitive character of the Chinese people; and the administration of the laws might have been carried out with courtesy, humanity and generosity. But none of these things was done. As so often happens in history, a necessary result was achieved in the crudest possible way because of inflamed passions and impatient, ruthless prejudice.

XI. Treatment of Chinese Immigrants at United States Immigration stations Chinese Immigrants of the privileged classes were often

45. McKenzie, R.D., op. c1t., 1927, p. 74 A law passed in 1935 has apparently remedied this last injustico. 
subjected to unnecessary and at times unpardonable treatment at the seaports of the United States, especially those at the Western Coast. Many criticisms have been made of the phys1cal conditions of the immigration stations where applj.cants for admission sometimes have to be detained for months. Grave errors in tact and judgment have been made from time to time, which have created great bitterness among the chinese.

Here is a letter from a high-grade joung man, born in Hawa11 of Chinese parents, but an American citizen by birthright. He was graduated from the UnIversity of Hawa11 and came on to the Chicago Theological seminary for graduate study. In August, 1931, he attended a Y.M.C.A. Conference in Toronto, Canada. This is his description of the way he was treated at the border, as printed in the Honolulu Star Bulletin of August 26, 1931:

"I was detained at Windsor, Canada, for elght hours, just on account of my being of Chinese descent. The fault was of the Canadian officlal. He was dumb, and he didn't follow instructions to allow delegates to the Conference to go through. Anyway I was impressed with the fact that I am a Chinese. My American citizenship didn't mean a thing. It was fust a scrap of paper. If a Negro says he is an American, and has no paper to show, he will be allowed to go through, no matter how ignorant he is, but if I am a Chinese with all my papers to prove that I am an American citizen, I am still taken off the train.

"The situation that burned me up the most was the treatment I recelved from the American offi-. clals at Nlagara Falls. I was Impressed more there that I am a Chinaman. I, an American citizen, was not allowed to visit the Falls because I was of Chinese descent. That takes the cake for insult

46. Palmer, A.W., op. c1t., 1934, p. 32 
and discrimination. I was too mad to do anything. I could have torn up my citizenship papers right then and there. If my Government is not going to protect my rights and treat me as any other cit1zen, I would rather be a Chlnaman and be treated like hell than be hypocritical about it.

"Yes, that is the thing I got out of the Conference at Toronto. We talk a lot about internationalism, but if these realities of discriminam tion are going to exist, all the conferences in the world and all the talk will not make me interm nationally minded.

"First thing they ought to do is to clean house and do away with this discrimination. Treat us all alike and don't pick on nations that are weak.

"American citizen of Chinese ancestry! What
does it mean? Well, I am going to find out."

Here is another article written by a Chinese student who

is now studying in the United States, published in the Chi-

nese student, Volume I, No. 4, 1936. The immigration ser-

vice referred to is the one at seattle:
"Nowhere is discrimination against the Chi- nese more obvious than in the United States Immi- gration Service. The Japanese, the Hindus, etc., are shown far more courtesy. In examining the passport of third-class passengers, for instance, the officers always attend first to the Japanese and the others; the Chinese come last. This has become an established practicel Whole categories of Chinese passengers are liable to be detalned, while the Japanese and the others, with the same immigration status, are freo from it (except in cases of obvious violations of United States laws). The average number of Japanese held for Investigation in one weok is about thre日; and others together (not including the Chinese) about twenty. And although the number of Chinese com- ing in within week is not higher than the num- ber of incoming Japanese, yet about thirty Chi- nese are detained each week. The place of deten- tion 18 a veritable prison. As you step down the boat, you are hustled into a van and taken d1- rectiy to 1t. At a side entrance, a ponderous iron door is drawn up, let down, and locked be- hind you. 
"The Chinese are segregated from the others. The detention room for the chinese has a floor space of thirty by forty feot. As you go in by a wooden door at one end, jou come to a grill through the bars of which you have a full view of the room. It is all solid cement, with a tremendous number of doublemdecked steel cots crowded together; some chairs and benches, and a lavatory walled in one corner. The gate in the grill is locked with a tremendous lock.

"The da1ly routine, too, is not unlike that of a prison. You are wakened at $6: 30 \mathrm{a} . \mathrm{m}$. Dressing for all takes about half an hour; then Jou make up jour own bed. Meals $\operatorname{come}$ at the same hours. Under the watchful eye of the guards, Jou march over to the mess-room and back, passing through a long corridor which is locked every ten feet. The mess-room 1s common to the detained of all nationalities, but the chinese are served last. Nominelly each is allowed fifty cents a day, however, the miserable fare in the name of 'Chinese food' could not have cost the commissar more than fifteen cents. The dining tables are long wooden structures, and the Chinese are served by groups of four, 1.e., two on each side opposite each other. Very often the two or three unpretentious dishes meant for four persons are shared by one or two additional mess-mates. Once the chinese petitioned to the officials to have the same food as the others, but this brought them only a storm of bad language and insult, and the cooks threatened to go on a strike if the Chinese' were to be served the same food as the others. You can order 'American food' from the kitchen through the guards, but what you get is often the remains of the meals of the officers or what is left over from several days before, and you must pay for it at exorbitant prices.

"The detention room is in very crowded condition. There is always a dense cloud of tobacco smoke hanging over the room. The windows are barred on the inside; you use a rod to open and close them. In the winter it is not always feasible to leave a window open very long. The room is simply stuffy and smells. You can ring for attendants, but if it is the chinese room; the bell may be pressed a dozen times without any response. If there should be any fire or similar accident, it would be simply disastrous. One night the room was insufferably warm, but on the radiator there was no wooden knob with which 
the Inmates could turn down the heat. They rang the bell and rang again, intermittently for sevoral minutes, till an attendant finally came, but he only reprimanded the inmates for their insistencel When one of them tried to argue, the attendant beat him with his fists. One Mr. Chen (from Shien-hul distr1ct, Kwangtung) was one day making a phone call, and during his conversation the guard who was watching him had a visitor downstairs. Immediately Chen was ordered to hang up the phone, and when he tried to argue, the guard beat him up and dragged him by his shirt collar to the room. In such cases their protests to the officers, as a rule, get nowhere. The Immigration Service even has solitary cells to pun1sh the unruly.

"For the people of the other nationalities there is a separate lounge room, and it is furnished with a phonograph and records, etc. The Chinese, in their one common cell, are denled the use even of books and magazines, let alone mus1c. The Chinese also have to provide their own soap, towel, and stationery.

\footnotetext{
"The most amazing thing is the method of questioning by the officials. A student from Chih-nan University, Shanghai, was questioned if he knew Latin. A Chinese born of parents with United States citizenship who comes to the country for the first time is regularly detained for investigation, while a Japanese, or a Hindu with the same immigration status, is free from 1t. To establish the identity of a person in such a case, he is asked questions so minute and trivial about his home and its locality that it is quite beyond human mentality to answer them perfectly. One person ras questioned about the boats his father used to take to go home to China, the dates of the voyages, the number of his baggages; the brand of cigarettes he used to smoke; the number of times he had sent money home, the dates of transaction, and what bank; the description of a certain time plece, its position on the wall, etc. One Mr. Wong (from Tai-shan, Kwangtung) was asked about the size and description of a lake near his village, the kinds and quantity of flsh it produced; the distance between his village and a certain trading place, the scenes on the way to that place and so on and so forth. Disagreement between the statements of the father and the son, even on detalls, is considered enough ground to refuse the son's landing. That was what happened to Wong.
} 


\begin{abstract}
"In the questioning very often the pretence of a 'fair trial' is abandoned. One woman (about thirty-five) was given too short a notice to appear one morning, and was consequently late by about four minutes. She was so brutaliy reprimanded that she all but broke down. Hour after hour one goes through such a grili1ng. The examining officers take turns. If the questioning is not completed in one day, it is continued on the next day. One may be detained a long time before his preliminary questioning; Wong walted three weeks, and then further investigations may be necessary before the final verdict is made known. Weeks may pass and then months, and there is no word. One may be detained as long as a year! Your family are detained in a different room from yours; you are allowed no visitors; your letters are read, and may even be se1zed. The women very often cannot conceal their tears. We are guilty of no crimes, why are we treated like this?"
\end{abstract}

XII. Conclusion

The history of the treatment of Chinese immigrants by the United States Government and people certainly is not a matter in which the citizens of the United States can take any pride. Race prefudice, bigotry, Ignorance and political ambition have played a prominent part in the agitation and have been instrumental in securing much of the legislation. The attitude and conduct of the United States contrasts unfavorably with the position of China, which has been one of patient, courteous, dignified but emphatic protest and willIngness to cooperate in securing reasonable regulation. The Chinese are industrious, intelligent and thrifty people. Their vices are no worse than those of the white man, and they have a smaller percentage of crime. It 1s, however, probably true that the exclusion of 
Chinese laborers has been of benefit to the United States. Since the characteristics and standards of Iiving of these Chinese immigrants (most of them came from underprivileged families) are so different, they are hard to be assimilated. But one should bear in mind also that the fallure of such assimilation has been due more to race prejudice and exclusiveness on the part of Americans than to unwillingness to be Americanized on part of the Chinese. It is significant that marriage between whites and Chinese or other Mongolians is prohlbited by nine states, elght of which are west of the Mississippl River and Include the states where the Chinese are most numerous. Unless Americans are willing to fraternize on terms of social equality with members of any race, there is great danger to national institutions in the presence of large numbers of other races within the country.

47. Inter-marriage between Orientals and whites is prom hibited in Arizona, California, Mississipp1, Missour1, Nebraska, Nevada, Oregon, South Dakota, and Wyoming, according to the United States census, 1930 
A BRIEF SURVEY OF CHINESE IMMIGRANT IIFE IN AMERICA

(1) Home Iife

(2) Rise and Decrease of Chinese Population

(3) Concentration of Chinese Immigrants

(4) Physical and Mental Ability

(5) Occupation and Economic Status

(6) Education

(7) Press and Public Bodles: Professional and Social

(8) Religious Affiliations

(9) Chinese Immigrants and National Relief 
Chapter III

A BRIEF SURVEY OF CHINESE IMMIGRANT LIFE IN AMERICA

Before outlining some of the vital problems concerning the Chinese residents of the continental United States, a general survey of the Chinese immigrant life in the American communities is necessary. To obtain a great varlety of these facts will help to secure an accurate picture of the Chinese population and tend to remove also many misconceptions which have resulted from the propaganda of interested agitators. The materials of this survey are obtained largely from the following sources: the United States Government documents, newspaper and magazine clippings, unpublishod dissertations and studies made by students who have spec1alIzed in the various phases of this study.

I. Home Life of Chinese Immigrants

- The Chinese, Iike most other immigrants, came at first as groups of single men and made a labor force that easily moved about wherever it was needed. But, unlike the Japam nese who soon began to bring wives and families with them, most of them remained celibate and had no family $11 \mathrm{fe}$. The 1930 United States Census reports that there are 143.3 men for every 100 women among the Japanese but 394.7 men for every 100 women among the Chinese. During recent years, 
many Chinese have brought their wives and families and set up normal homes, but most of these cases were confined to the Pacific states. For instance, there are at present 12,033 men to 4,270 women in San Francisco, and at Oakland 2,011 men to 1,037 women; the ratio is almost two to one. (See Table I)

TABIE I

SEX DISTRIBUTION OF CHINESE IN AMERICAN CITIES

\begin{tabular}{lrrr} 
& Male & Female & Total \\
\hline Boston, Mass. & 1,346 & 249 & 1,595 \\
Chlcago, Ill. & 2,408 & 349 & 2,757 \\
Los Angeles, Cal1f. & 2,228 & 781 & 3,009 \\
New York, N.Y. & 7,549 & 865 & 8,414 \\
Oakland, Cal1f. & 2,011 & 1,037 & 3,048 \\
Philadelphia, Penn. & 1,474 & 198 & 1,672 \\
Portland, Ore. & 990 & 426 & 1,416 \\
San Francisco, Cal1f. & 12,033 & 4,270 & 16,303 \\
Seattle, Wash. & 969 & 378 & 1,347 \\
\hline
\end{tabular}

TABLE II

REGIONAL SEX DISTRIBUTION OF CHINESE IN THE UNITED STATES

Districts

New England

Middle Atlantic

East North Central

West North Central

South Atlantic

East South Central

West South Central

Mountain

Pacific
Male Femele

\begin{tabular}{rr}
3,233 & 561 \\
12,503 & 1,502 \\
5,421 & 919 \\
1,431 & 307 \\
1,477 & 392 \\
589 & 154 \\
1,237 & 345 \\
2,675 & 577 \\
31,236 & 10,395 \\
\hline 59,802 & 15,152
\end{tabular}

* United States Census, 1930 
The ratio on the Atlant1c coast 1s, however, st111 low. New York Clty has 7,549 Chlnese men but only 865 women; Boston, Massachusetts, has a total Chinese population of 1,595; only 249 of whom are female. Such unequal sex distribution is largely due to the effect of general political and economic forces, and to the immigration laws enacted by the United States Government which have prevented the union of the many Chinese families. There are children living in China who cannot join one or both of their parents living in the States; similarly, there are many parents, mostly mothers, who cannot foin their American-born children who 11ve in the United States. The sad situation of broken fam111es is one of the tragic problems facing the Chinese immigrants, and the abnormal home Iffe has caused many moral and social problems in Chinese communities.

It is interesting to notice here the Chinese marriage system. In China, and the orlent generally, marriage is ordinerily not a matter decided upon by the two individuals most concerned, but is arranged by their elders and is a family matter. The young man or woman dutifuliy accepts the mate chosen and provided by the family. Hence, if a Chinese In America desired to marry, it was hardly necessary for him to take the long and expensive journey to China and conduct a courtship. All that could just as well be arranged by the two families concerned and his bride could make the journey and meet him in America. This marriage system is commonly practiced among Chinese immigrants and is of course resented 
by popular American opinion.

The Chinese, I1ke all Immigrant groups, have larger fam111es than Americans. Th1s is partly due to the fact that Chinese women who have come to the United States are mostly of chlld-bearing age. The statistics as to the Chinese birth rate is therefore normally high. These Amerlcan-born Chinese children are cltizens by birthright, regardless of the fact that their parents cannot be naturalized. They attend the United States public schools and become readily Americanized many cannot read, write or speak Chinese - yet they meet with discrimination and race prefudice in their effort to earn a living and in social contacts. Being "marginal men," that 18, persons not able to participate fully in elther culture group, that of their parents or that of American society, they present the real problem today.

\section{R1se and Decrease}

The Chinese numbered 74,954 in the Continental United States in 1930. According to the 1924 Annual Report of the Commissioner-General of Immigration, only 42 Chinese are recorded as entering the United States prior to 1853, 42 more during 1853 and 13,100 in 1854. From then on the annual rate varied between three and five thousand unt1l in 1859 the number of arrivals leaped to 12,874 , making a total of 34,933 Chinese Immigrants in Continental United States in 1860. But starting with 1860 the Chinese population Increased rapidly, reached 63,199 in 1870; 105,465 in 1880; 
and $107,488 \cdot$ in 1890 .

TABLE III

NUMBER OF CHINESE IN THE UNITED STATES AND RATE OF INCREASE

\begin{tabular}{lrcc}
$\begin{array}{l}\text { Census } \\
\text { Year }\end{array}$ & Number & Decade & $\begin{array}{c}\text { Percentage In- } \\
\text { crease }\end{array}$ or Decrease \\
\hline 1860 & 34,933 & & \\
1870 & 63,199 & $1860-70$ & 80.9 \\
1880 & 105,465 & $1870-80$ & 66.9 \\
1890 & 107,488 & $1880-90$ & 1.9 \\
1900 & 89,863 & $1890-00$ & 16.4 \\
1910 & 71,531 & $1900-10$ & 20.4 \\
1920 & 61,639 & $1910-20$ & 13.8 \\
1930 & 74,954 & $1920-30$ & 21.6 \\
\hline
\end{tabular}

* Fifteenth Census of the United States, 1930, Population, Vol. II, p. 32

In Table III which shows the number of Chinese in the United States at each census year since 1860, it is interestIng to note that the Chinese population increased in number up to 1890 and then steadily declined until 1920. In the decade 1920-30 it showed a substantial increase, although there were st1ll appreciably fewer Chinese in the United States in 1930 than there were in 1890.

Various reasons account for the decline of the Chinese population. In the first place, Chinese Immigrants with very few exceptions have been excluded since 1882 when the first drastic exclusion law was passed. In the second place the number of departures has often exceeded the number of arrivals. For Instance, according to the Annual Report of the Commissioner General of Immigration of 1924, 228,899

1. Based on the Unfted States Census 
Chinese arrived between 1853 and 1880. But the United States Census for 1880 gives only 105,465 in the country; thus something like 120,000 must have returned or died in the intervening years. During $1880-90,61,711$ are reported entering; about 60,000 must have returned in order to leave but 107,488 in the country in 1890. In the third place, the disproportion of the sexes among the Chinese in America prevents any rap1d natural increase. In 1930, among the Chinese in the United States, there were 394.7 males per 100 females; In earlier years this disproportion was even greater, being $1,430.1$ in 1910, and 695.5 in 1920. In 1910, there were fewer than 3,000 Chinese females fifteen jears old and over; in 1920, the number was 4,407 ; in $1930,8,169$. Finally, many of the Chinese here are of advanced age and the death rate has been comparatively high. The increase of some 13,000 in the Chinese population In the decade 1920-30 is difficult to explain, since both the immigration figures and the vital statistics for the period register a net loss in this group. It may be accounted for on the basis of 1llegal entry - and there has long been a problem of smuggling Chinese into the country or it may arise from the increased proportion of females in the Chinese population which caused an excess of births over deaths. In 1920, the foreign-born among the Chinese made up

2. Woofter, T.J., Races and Ethnic Groups In American Iife, 1933, p. 21 
seven-tenths of the total; in 1930, less than three-fifths. There is a further possibility of some error in the census enumerations.

III. Concentration of Chinese Immigrants

The Chinese immigrants are potentially the most static of the country's labor group. They are not moblle because of culture traits which have made them closely attached to the home and have emphasized the accumulation of stabilizing possessions. The kinds of occupations which they follow have also helped in making them increasingly permanent residents.

During the early days, the chinese immigrants were concentrated along the Pacific Coast. In 1880, on the eve of exclusion, the Chinese in California numbered 71,244 out of the total population of 864,696 , or almost nine percent $(8.68 \%)$. Thus the Chinese immigration problem was originally a Pacific Coast problem or primarily a California problem. But since the passage of the Exclusion Law of 1882, there has been a tendency toward the diffusion of the Chinese population throughout the states of the Union. Between 1880 and 1820, the number of Chinese residents in California was reduced from 71,244 to 24,230 , or from 8.68 percent of the population of the state to 0.65 percent. (See Table IV).

\section{United States Census}


TABLE IV.

TOTAL POPULATION OF CALIFORIIA POR THE YEARS 1850-1930 AND TOTAL CHINESE *

\begin{tabular}{lrrc} 
Year & $\begin{array}{c}\text { Total } \\
\text { Population }\end{array}$ & Chinese & $\begin{array}{c}\text { Percentage of } \\
\text { total }\end{array}$ Population \\
\hline 1850 & 92,259 & & \\
1860 & 379,994 & 33,149 & 9.19 \\
1870 & 560,247 & 45,404 & 8.79 \\
1880 & 864,696 & 71,244 & 8.68 \\
1890 & $1,213,398$ & 69,382 & 5.97 \\
1900 & $1,485,053$ & 42,297 & 3.08 \\
1910 & $2,377,549$ & 23,003 & 1.52 \\
1920 & $3,426,861$ & 24,230 & 0.84 \\
1930 & $5,677,251$ & 27,988 & 0.65 \\
\hline
\end{tabular}

* Based on the United States Census

The greater diffusion of the Chinese population and changes in ocoupation account for the disappearance of the Chinese Immigration problem and the vastis different att1tude of the American people toward the Chinese as contrasted with the Japanese. The United States Census in 1930 shows a marked Increase of Chinese population in New England, the Midale Atlant1c, and the East Korth Central States. The Southeastern Central states have the smallest number of Chinese imigrants (See Table II). The total Chinese population 18 therefore so generally distributed that it does not appear menacing in any particular spot.

Aside from the geographical distribution of the Chinese throughout all the states, which results in a minimum of 1rritation among the whites, there is also a correspondingly marked tendency on their part to segregate themselves in the heart of a fer large cities - the Chinatowns. Such segrega- 
tion of the Chinese near the centers of the largest cities gives them an impersonal relationship in the community structure and permits them to live less in contect with the native Americans. Instead of being considered as a disturbing element in the American comercial life, the Chinatown is looked upon as a commercial asset - a point of attraction for tourists.

Another reason for the favorable attitude of Americans toward the Chinese is that the Chinese have graduallJ withdrawn from most of the competitive occupations. They are no longer engaged in agriculture, lumbering, or mining, and they participate to a very limited degree in types of business in which Americans compete. Their sphere in business is confined almost exclusively to transactions with their own people or to supplying wants in American communities not catered to by whites.

More than any other racial or nativity group, the Ch1nese are an urban people, 81.1 percent of them living in c1t1es in 1920 and 87.7 percent in 1930 . In this respeot they differ radically. from the other colored immigrant groups in the population. This is probably due to the fact that practically all the Chinese immigrants are in urban occupations. The following Table shows the rate of increase of Chinese inhabitants in cities during the thirty jears, from 1900 to $1930:$

4. McKenzie, R.D., "The Oriental Invasion," Jourmal of Applied Soc10logy, Vol. $\mathrm{X}$, Nov.-Dec., 1925, pp. 125-126 
TABIE V.

IMCREASE OF CHINESE IMMIQRANTS IN AMERICAN CITIES

\begin{tabular}{lrrrr} 
C1tI & 1930 & 1920 & 1910 & 1900 \\
\hline Ch1 cago, I11ino18 & 2,757 & 2,353 & 1,778 & 1,186 \\
New York C1ty & 8,414 & 5,822 & 3,609 & 6,321 \\
San Franc1sco, Cal. & 16,303 & 7,744 & 10,582 & 13,954 \\
Los Angele8, Cal. & 3,009 & 2,063 & 1,954 & 2,111 \\
Oakland, Cai. & 3,048 & 3,821 & 3,609 & 950 \\
Seattle, Washington & 1,347 & 1,351 & 924 & 438 \\
Portland, Oregon & 1,416 & 1,846 & 5,699 & 7,841
\end{tabular}

* Published in The Chinese Student, Vol. I, Nos. $7-8,1936, p \cdot 27$ Based on United States Census

- In the above Table, it is interesting to note that the Chinese population in Eastern and Mid-western states has increased much faster than it has in the c1ties on the Pacific Coast. The city of Chicago has trebled her Chinese population in thirty jears while in Portland, Oregon, Chinese have decreased from 7,841 in 1900 to 1,416 in 1930. Here 1s a clear Indication that the Chinese immigrants have moved eastward due to the blased racial attitude of the people in the Pacific states. The significant increase in the Chinese population of the larger cities during the decade 1920-1930 1s probably due to the fact that the depression caused many Chinese who have not been able to continue earning a Iiving In the country or smaller torms to move to the larger c1t1es where they could depend on their relatives and friends for their support. 
IV. Physical and Mental Ab1lity

There are very slight differences in physical and montal capacities between the whttes and those Chinese who are born in this country and oducated in the same schools. In fact, the differences are so ilght that there is no warrant for supposing that Chinese and whites should onter different occupations

\section{A. Height and We1ght}

The Caucasians as a group are taller and heavier. than the Mongollans. The Chinese being one of the Mongollan types are generally shorter in stature and weigh loss than the Americans, although they are taller and heavier than the Japanese. So far there has been no study made to show the difference in height and welght between the American-born ChInese and the Chinese born In China; although data accu6

mulated by Kanzaki Indicated that American-born Japanese are taller and heavier than Japanese born in Japan.

B. Physical strength

Porteus presents comparative strength-test results between the chinese, the whites and several other racial groups (See Table VI).

5. Strong, E.K., The Second Generation Japanese Problem, 1934 , P. 167

6. Kanzak1, "Is the Japanese Menace in America a Realitj?" Annals, The Amerioan Academy of Political \& Social Sc1ence, V01. XCIII, January, I921, p. 88

7. Porteus, S.D., The Psychology of a Primitive People, 1931, Chapter XX; Annotations from pages 345 and 347 
TABLE VI.

STRENGTH-TEST RESULTS

\begin{tabular}{|c|c|c|c|c|c|c|c|c|c|}
\hline Races & Ho. & $\begin{array}{l}\text { Index of } \\
\text { strensth }\end{array}$ & $\begin{array}{l}\text { Right } \\
\text { Grip } \\
(\mathrm{x} \cdot \mathrm{B} \cdot)\end{array}$ & $\begin{array}{l}\text { Left } \\
\text { Grip } \\
(\mathrm{K} \cdot \mathrm{E} \cdot)\end{array}$ & $\begin{array}{l}\text { Vital } \\
\text { Capac- } \\
1 \text { ty } \\
(c u .1 n) \\
\end{array}$ & $\begin{array}{l}\text { Back } \\
\text { Lift } \\
(\mathrm{K} \cdot \mathrm{R} \cdot)\end{array}$ & $\begin{array}{c}\text { Back \& } \\
\text { Leg } \\
\text { LIft } \\
\left(\mathrm{X} \cdot \mathbf{B}_{\cdot}\right)\end{array}$ & $\begin{array}{l}\text { Arn \& } \\
\text { Shoulder } \\
\text { (K.g.) }\end{array}$ & $\begin{array}{r}\text { stature } \\
\left(c . m_{0}\right) \\
\end{array}$ \\
\hline $\begin{array}{l}\text { P1lipinos } \\
\text { Japanese } \\
\text { Austral1en }\end{array}$ & $\begin{array}{l}53 \\
86\end{array}$ & $\begin{array}{l}397.5 \\
399.5\end{array}$ & $\begin{array}{l}44.4 \\
46.0\end{array}$ & $\begin{array}{l}42.2 \\
41.9\end{array}$ & $\begin{array}{l}177.0 \\
207.2\end{array}$ & $\begin{array}{l}138.3 \\
118.5\end{array}$ & $\begin{array}{l}172.6 \\
192.8\end{array}$ & $\begin{array}{l}25 \\
34.8\end{array}$ & $\begin{array}{l}159.6 \\
161.5\end{array}$ \\
\hline $\begin{array}{l}\text { Aborigines } \\
\text { Chinese } \\
\text { White (students) } \\
\text { White (Smediey }\end{array}$ & $\begin{array}{r}108 \\
52 \\
\frac{55}{55}\end{array}$ & $\begin{array}{l}432.0 \\
438.7 \\
484.6\end{array}$ & $\begin{array}{l}46.6 \\
50.0 \\
54.0\end{array}$ & $\begin{array}{l}45.3 \\
45.3 \\
48.6\end{array}$ & $\begin{array}{l}180.0 \\
211.1 \\
27.0\end{array}$ & $\begin{array}{l}139.0 \\
123.2 \\
\frac{139.3}{139}\end{array}$ & $\begin{array}{l}201.0 \\
\frac{220.2}{242.7}\end{array}$ & $\begin{array}{l}23.6 \\
37.0 \\
60.4\end{array}$ & $\begin{array}{l}169.5 \\
166.8 \\
115.8\end{array}$ \\
\hline $\begin{array}{l}\text { \& Hastings) } \\
\text { Part Hawalians }\end{array}$ & 78 & 493.1 & $\begin{array}{l}49.0 \\
53.5\end{array}$ & $\begin{array}{l}49.0 \\
48.5\end{array}$ & 228.9 & $\begin{array}{l}151.0 \\
138.3\end{array}$ & $\begin{array}{l}189.5 \\
252.8\end{array}$ & 45.2 & \\
\hline
\end{tabular}

* Based on the results of the comparative strengthtest made by Porteus in 1931 
According to these findings, the chinese have less muscular strength than the whites and Hawalians; but they have much more than the Japanese and Filipinos. The significance of these findings, however, is very difficult to determine. Evidently, as Porteus has pointed out, muscular strength is not necessarily an indicator of muscular performance, for in the Hawallan Islands the Hawalians far exceod the ChInese and Jepanese in strength tests but are notoriousiy poor workers, whlle the Japanese, desplte their poor muscular equipment, are doing very efficient industrial work. This, therefore, indicates that the mental or temperamental attributes which go with industrious habits are much more important than the original physical equipment.

Although the whites are superior in muscular strength, the Chinese show superiority in endurance and patience, in quickness of reaction, and are not so eas1ly exhausted. The demonstrated speed and accuracy of muscular co-ordination of the Chinese, together with their recognized ability to work long hours, leads one to the conclusion that their physical abilities will not be found insufficient for almost any type of work they may wish to undertake in competition with the whites.

C. Health Conditions

The Chinese have been acoused by popular tradition of being somewhat lacking in cleanliness, in spite of their slgnal success in the laundry business. This is not, however, due to the fact that Chinese are necessarily inferlor 
physically to the whites, rather because of the pecullar economic and social position in which they have been placed. After having becone adapted to one tjpe of c1vilization for centuries, they suddenly find their environment radically changed. The result is a period of maladjustment during which the older modes of adaptation to the problems of phjs1cal health are inappropriate, while the newer modes, sultable to the conditions of twent1eth-century America, hare yet to be learned. Ior economic position adds greatly to the difficulties of the immigrants. This applies not only to the Chinese, but also the forelgn-born Buropeans, the Mexicans, the Negroes and the Indians.

The Chinese living in the Southwestern and Pacific States are mostly working-class people, separated entirely by nationality and race from the rest of the community; thus many are living under conditions which make proper regard for health very difficult. In the Missiseippi delta, the Chinese usually 11ve behind their grocery stores. They 11ve cheaply and humbly in order to save money for the1r trips back home. Many first-generation Chinese, belng superstitious, belleve that if they die away from their old home, their apirits w11l wander forever without finding rest. So while they are here In this country, they try to live in very humble ways in order to cut down expenses and save money to go back. There has undoubtedly been improvement in health cond1tions during recent jears among these under-privileged Chinese due largely to the influence of Chinese students, but 
how much or how extensive the improvement has been it is im8 possible to say. According to Dr. Woofter, the death-rate for the Chinese immigranta is not as high as for many other Immigrant groups; and there 18 a steady decline in the rate of infant mortality. The deaths among the Chinese are generally caused by the following principal diseases:

Tuberculosis hes long been the most prevelent cause of death among Chinese. The Chinese have been considered to be inherently susceptible to tuberculosis; but recently medical science has tended to emphasize social and economic factors rather than purely racial factors as being responsible for tuberculosis. So the matter of checking the spread of tuberculosis among Chinese is mostly dependent on better wages, better nutrition, shorter hours, a larger degree of rest and recreation, and better working conditions, particularly with respect to a reduction in dust, and an improvement in light and ventilation.

Heart disease is rapidiy becoming one of the chief causes of death among chinese. The primary factor for this disease is that of environment. Chinese are to a large extent manual laborers, doing work of a heavy and tiresomo nature which 18 conducive to the development of this disease.

Venereal disease among Chinese is estimated to be high among those who $11 \nabla 0$ in urban communities. This is, of

8. Woofter, T.J., op. c1t., 1933, p. 146 
course, due to unequal sex distribution and social disorganiration, incident to the urbanization of the Chinese.

The cancer rate for the Chinese has been rising in recent years, but it is st1ll well below that for the whites. However, cancer of the heart and of the genital organs seems to be considerably higher among chlnese women.

The infant mortality rate is high among Chinese immigrants due largely to ignorance and poverty. This 1s, however, true also of Indians and Negroes.

One of the most prevalent disease among chinese is trachoma, which, though not fatal, frequently leaves permanent injury to the eye and may finally result in blindness. Since the Chinese are scattered all over the country, It has been hard to obtein accurate figures concerning birth and death rates. But it is generally agreed that Chinese colonies in large cities ile within the field of municipal public agencies which have done much in reducing mortality rates.

D. Intelligence

Three lines of investigation have been followed in the search for evidence on comparative mental ability of Chinese and other raclal groups:

1. The Relationship of Head Size and Brain Capac1ty to Intellectual Ab1lity

Many anthropologists suggest that there must be a relationship between brain capacity and intelligence.

9. Ib1d, 1933, p. 146 
According to the studies made by Porteus and Babcock, the Anglo-Saxons have brains with larger cublc capacity than the Chinese and Japanese, and therefore it is assumed that AngloSaxons have superior intelligence. However, such a conolusion 18 very arbitrary. In view of the present limited state of our knowledge, we cannot draw any conclusion as to the significance of these differences in terms of intellectual capacity unt1l we know more about the relationship between bodily size and cranial capacity or about variations in hoad shape and skull thickness and other simflar factors among the various races.

\section{Measurement of Inteli1gence}

Perheps the most complete study of the intelIigence of Chinese children made with the basic Binet scale 11 (Stanford Revision) is that of Graham, made in 1925. Her subjects were Chinese children attending the Orlental school In Sen Francisco, a public school attended exclusively by Chinese and Japanese (see detalled description in Chapter III - Education). Only about one-fifth of the seventy-three children tested were born in China, but all were of Chinese parentage and came from Chinese-speaking familles. All were twelve years old, and as every twelve-year-old in the school was tested, the group was as unselected as it was possible

10. Porteus and Babcock, Temperament and Race, 1926, p. 168 11. Graham, V.T., "The Intelligence of Chinese Children in San Franc1sco," Journal of Comparative Psychologr, Vol. VI, 1926, pp. 43-7I 
to make it and should be reasonably "representative of the population of the school."

Miss Graham used a wide variety of tests, including: a series selected from the Cornell scale for determining mental age; the Kohns block-design test; group tests which included Mentimeter School group 2a; Thorndike-feCall Reading Scale; the National Intelligence Scales; and the Stanford Revision of the Binet Scale. She gave the same series to a white public school group for purposes of comparison.

Miss Graham analyzed her data by an inter-correlation technique as well as by comparison of score results and mental and educational ages. She concludes:

". We have found that in pure memory processes of the visual tjpe, where meaning and language are kept at a minimum, the Chinese is fully the equal of the American. - He evinces superior ablilty in certain types of concrete problem-solving where the nature of the response may be described as a sensori-motor one. In solving other types of problems, however, he 18 inferior. . When we come to a broader conception of intelligence, whether as the so-called common factor existing in and influencing all performances, or as the complete integration of processes, and compare the chinese with the American in respect to totality of performance, the advantage always rests with the American.

"The results of our investigation show a den clded language disability in the case of the Ch1nese, which is so complex that it cannot be locallzed by parcelling out various language elements . - In consideration of the close interrelationship existing between language and intelligence, it is fair to say that these same language limitam tions are a result of, or at least are concomitant with, mental ilmitations.

"This 18 bj no means equivalent to saying that the Chinese are mentaliy inferior... The Chinese come well within the lower border of the 
limita which have been empirically found to include the normal Americans. . . It is well to point out that our results bear out the oftrepeated verdict that there is no more difference between racial intelligence normo than there is between the norms of varjing social strata vithin a givon race." 12 13

Wolcott in 1918 measured the intelligence of senlors in the higher schools of Tsing tua College, using the technique emplojed in the stanford Revision of the Binet test as outm lined in Terman's Measurement of Intelligence, but without using any of the test materials commonly used. He made his own vocabulary test, which he used only at the fourteen-year level. On the scale thus arbitrarily modified, he obtained for the sixty-three subjects examined IQ's ranging from 81 to 122, of which 44 exceeded 100 and 18 were below 100 . His results, of course, are merely suggestive. 14

Young in 1921 tested 109 Chinese children in San Franc1sco by means of the Stanford-Binet test, translating the tests into Chinese "whenever it was necessary." He found a medium IQ of 97 for his group. He believes that the intelIigence of Chinese children is not far inferior to that of American children.

Certain Inferences seem to be clear from the above studies summarized in this measurement of intelisgence:

12. Graham, V.T., op. c1t., 1926, pp. 68-70

13. Wolcott, C.0., "The Intelligence of Chinese students," School and Soclety, Vol. XI, 1920, pp. 474-80

14. Toung, $\bar{K} \cdot T$. Whe Intelligence of Chinese Children in San Francisco and Vicinity," Journal of Applied Psychology, Vol. V, 1921, pp. 267-14 
a. It is highly probable that the innate mental capacity of Japanese and Chinese children 18 greater than their Binet I.Q.' ascertained on scales administered in English would Indicate. There is reason to believe that mental ages so derived are at least two to four months too 10w.

b. Chinese and Japanese children seem defInitely inferior to American white children in mental proc0880 involving memory and abstract thinking based on meanIngs or concepts represented by the verbal symbols of the ingl1sh language.

c. Chinese and Japanese children are probm ably at least equal and possibly superior to American whites in mental processes involving memory and thinking based upon concrete, visually presented situations of a nonverbal character.

W1th one exception the comparative studies 80 far made Indicate that Chinese and Japanese are retarded somerhat in school with respect to subjects of a linguistic nature, but in arithmetic and spelling seem to be superior to whites. However, one extensive study shows equality of performance in reading tests as well as in arithmetic. In conclusion, one should recognize that in prectically every study made the Chinese were able to obtain scores approximating those made by the whites.

3. Evaluation of Educational Aohlevement The third set of studies was concerned with 
educational achlevement, as recorded in achievement-test scores, teacher's ratings, and age-grade distribution. The data relating to this phase of studies are somewhat conflicting. The earlier studies (Darsie, Bell, Graham) show a distinct educational retardation of children of chinese and Japanese parentage manifesting itself in lower achievement-test scores in school subjects calling largely for lingulstic ablity; but in arithmetic and in spelling they are superior to whites. However, all studies in general show equality of performence on reading tests as well as on arithmetic.

\section{E. Ab1lity to Use Fnglish Language}

It is generally agreed that the Chinese can master the English language much more easily than can the Japanese. The writer, for example, has met many Chinese who speak beautirul English, but has never met a Japanese who was eree from accent, always used the article correctly and did not occasionally employ the Japanese order of words in the sentences. Many data pertaining to lingulstic ab1lity support the hypothesis that the Chinese are very capable of learning languages and that the Japanese are deficient in linguistic ab1lity if An editorial in The Oriental Outlook supports th1s view:

15. Strong, E.K. Vocational Apt1tudes of Second-Generat1on Japanese In the UnIted States, I933, pp. 39-44

16. The orientel out1ook, Vo1. I, Merch, 1933, p. 4 
"W1thout being aware of it, perhaps, Japan has prejudiced pubilc opinion in America against herself by what may seem to be a trivial thing. But none the $10 s 8$ it has been a potent fector in the determination of our foreign policy in oriental affairs. It is the atrocious manner in which, with few excoptions, the spokesmen for Japan have handled the English language. Add to this the further offense comitted by the Japanese in the crudely worded and ungrammat 1cal printed documents with which the country has been flooded, and you have the answer to why the United States is not more sympathetic to her next-door neighbor cross the Pacific. The average American is prone to look upon one who speaks Fnglish haltingly as an ignorant and uncouth forelgner. The facility with which Chinese diplomats express themselves in Flawless English, together with the fluency of practically all chinese leaders who have appeared in th1s country, has without question helped to mould public opinion in China'g favor."

F. Personality Traits - Honesty and Trustworthiness The Chinese have long been known as very honest people while the Japanese have been accused of being trick and unreliable. A well-known American legend stated that the Japanese are such a dishonest race that they cannot even trust one another but must employ honest Chinese cashiers in their banke. The basis of this story lies probably in the fact that the Chinese have been for ages the bankers and money changers of the Orient and when the Japanese suddenly came out of their seclusion and had to develop commercial methods and institutions almost over night they naturally at first emplojed Chinese tellers to deal with forelgn moriey, for no one else knew the ahifting values of the many currencies of the Asiatio world.

It is also probably true that comercial procedures had been more highly developed among the Chinese through their 
merchant guilds, and the 1dea of a contract was better understood and more strictly adhered to, than among the Japanese, who had only recently emerged from reudallam and to whom personal relationship and mutual respect, honor and good-w11l were more important than abstract contractual relationships. At anj rate, popular opinion in America has it that "the honest Chinaman" is more likely to keep his contracts than the Japanese.

In a study of credit ratings made by John Hall, a graduate student of business at Stanford University, in the San Francisco and Los Angeles areas, it was discovered that the Chinese made a botter showing in retallers' credit ratings than did wh1tes and Japanese. They pald more promptly, took discounts more often and paid slowly or very slowly less often than did the other two groups.

18

During 1928-30, Strong made a survey of the ratings of housewives living in Berkeley, LOs Angeles and San Francisco for efficiency and trustworthiness of servants. H1s studies reveal that housewives rate Chinese indoor servants very highly for both efficlency and trustworthiness (see Table VII). Although they are not rated as highly as are scotch and scandinavian servants, jet they are rated considerably higher than American servants.

17. Strong, R.K., op. c1t., 1933, pp. 142-146

18. Ib1d, 1933, pp. 147-153 
TABIE VII

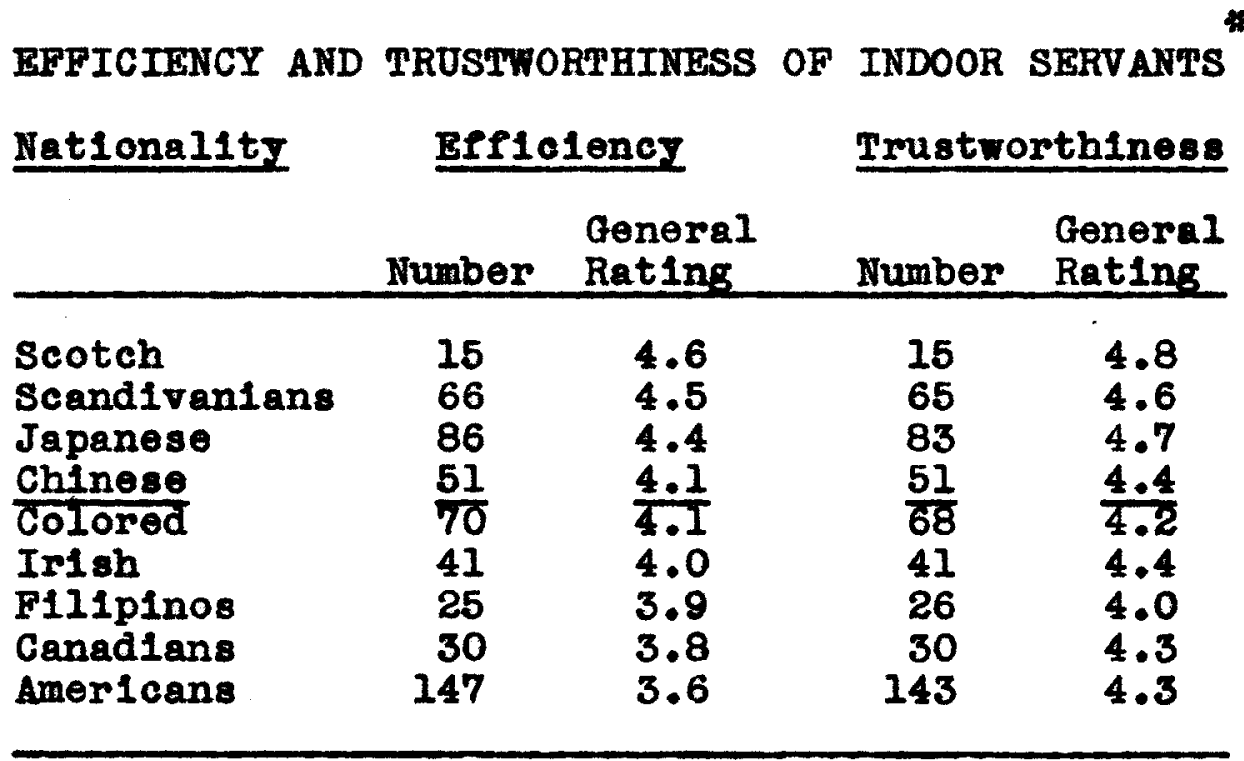

* Based on Strong's Surver of the ratings of housewives in 1829-30

G. Crime and Delinquenoy

1. Crime: Almost every study made regarding

Oriental crime in merica proved that the Chinese have estabIlshed an enviable record. According to Professor Walter 0. Beach of Stanford University, the actual criminal record of the Chinese 18 remarkably low. Some interesting facts may be found in his book, Oriental Crime in California. For instance, the proportion of serious to minor crimes, that 18, of felonies to misdemeanors, is remarkably low. We would summarizo his data as follows: 19

"During the entire period studied (1900-1927) there was a total of 71,626 Chinese arrests, of which only 1,026 were for crimes punishable by death or imprisonment in a state prison." This 18 only 1.44 percent of the total volume of

19. Beach, W.G., Oriental Crime in California, 1932, pp. 92-93 
Chinese crime. "During this period the total of all commitments to San Quentin penitentiary was 55,508 of which 978 were Chinese or 1.8 percent." In other words the Chinese commitments for serious crimes against the person and against property were only slightly above their proportion of the population; which was 1.5 percent; indeed, if an equalization were made on the basis of the proportion of males in the population, the Chinese would have a rate of crime below the average. In 1910 there were 33,003 Chinese males out of a total male population of $1,322,978$ or almost exactly 2,5 percent. In other words, with 2.5 percent of the male population, the Chinese provided only 1.8 percent of the prison population of the State.

The great proportion of Chinese offenses as carefully analyzed by Professor Beach, prove to be what are classified as "offenses against public policy and morals." Thus $44 \%$ of them grow out of chinese lotteries, $22 \%$ out of other forms of gambling, 11\% out of oplum smoking, $5 \%$ out of vagrancy (which covers almost anything) and $4.75 \%$ out of violations of miscellaneous city ordinances. It is noteworthy that violations of traffic laws constitute $1 \%$, and drunkenness one-third of one percent of the total offenses reported. Beach polnts out also that there was a deoline in the number of commitments of Chinese criminals to the prisons between 1900-1980 although the rate of decrease in commitments wes amaller than the rate of decrease in population. Furthermore, many of these crimes are not considered as 
crimes in China, nor are they antagonistic to Chinese public sentiment. So the defects of their conduct do not have quite the same meaning that they rould have if they had been violating their ow standarda.

The secret of this splendid record probably $11 \theta$ in the high esprit de corps of the Chinese community, their strong family loyalty, their wholesome individual purity and their high educational 1deals. During recent years, there has been a growing enthusiasm among the Chinese to take part in all c1vic enterprises in the leading cities of America, such as community chest movements, etc., and to make a good record in all community welfare and charity programs. They excel in pageants and parades and are coming more and more to be depended upon for colorful and beautiful additions to all community celobrations. Even in Chicago, when an international program is put on, it is usually the chinese or Japanese group that draws the crowd.

2. Juvenile Delinquency The Chinese have also 20 contributed very few juvenile delinquents in America. Strong has examined the files of the Probation Departments and of the Juren1le House of Los Angeles, San Francisco, Alameda, and Fresno Counties for the last ten years and found records of 338 Chinese juvenile delinquency cases (see Table VIII). of the 338 casea, 123 are for dependency, 32 for traffic violation, 6 for investigation, and 3 for charges unkmown.

20. Strong, E.K., op. c1t., 1933, pp. 155-158 
This leaves but 175 actual delinquency cases in ten years in the four largest counties of California where more than half of the Chinese population of Califormia 11ve. of the 175 offenses, larceny 18 the most common among them (23\%), then ragrancy $(14 \%)$, stealing $(12 \%)$, truancy $(11 \%)$, incorrig1b1lity $(10 \%)$, and burglary $(9 \%)$.

TABIE VIII.

CLASSIFICATION OF THE CHINESE OFFENSES ACCORDING TO THEIR NATURE IN FOUR COUNTIES FOR THE LAST TEN YEARS (1920-1930)

Ios San Angeles Francisco Alameda Fresno

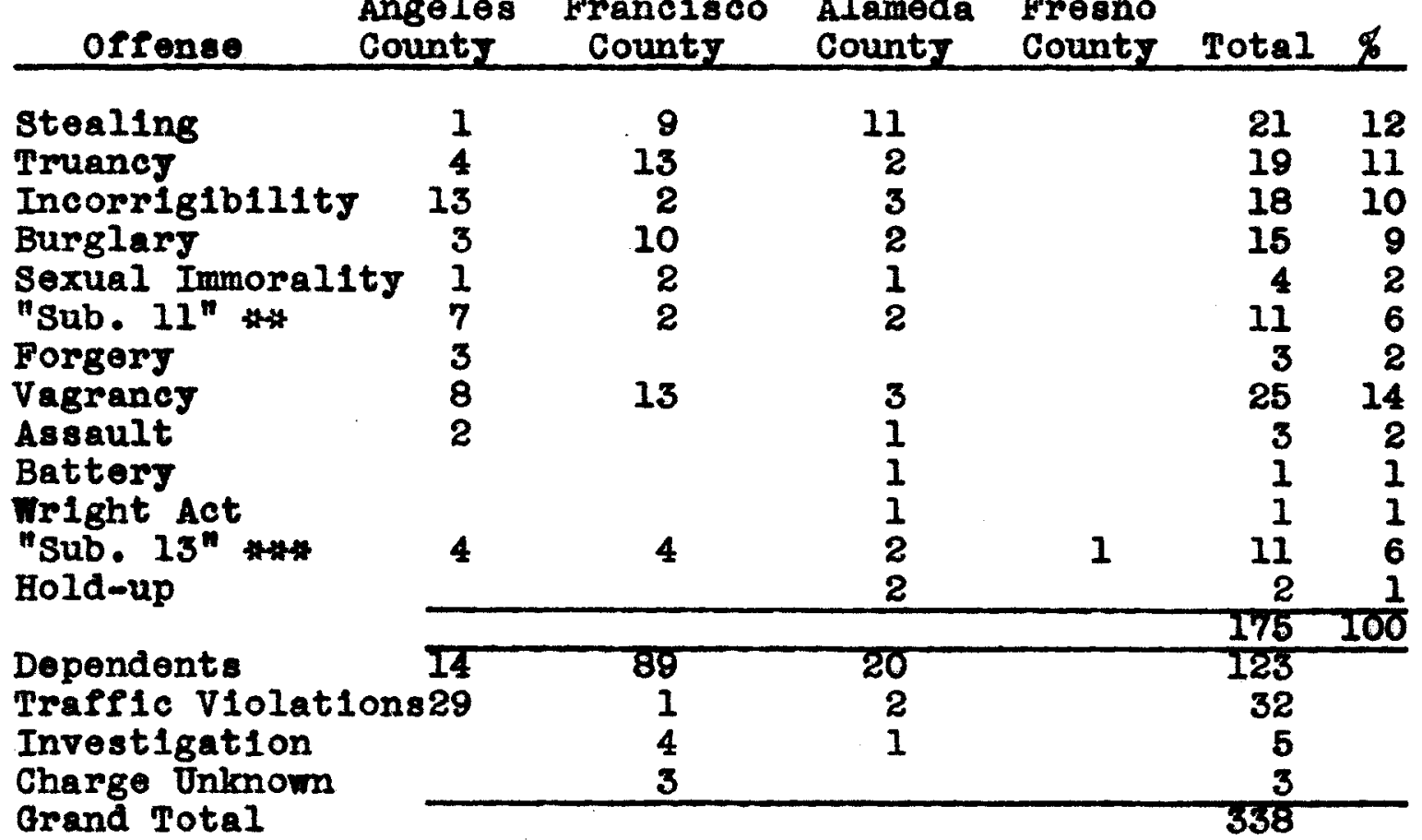

* Based on Strong's study of Juvenile delinquency records in California, 1920-1930, op. c1t., 1933, p. 157

* "Sub. 11," "Who is leading, or from any cause is in danger of leading, an Idie, disolute, lewd, or Immoral life," California Juvenile Court Lav. 1919

**x- "Sub. 13," "Who violates anj law of this state or any ordinance of any tow, c1ty, county, or city and county of this state defining crime," ibid 
The age distribution of these juvenile delinquents is shown in Table IX. The average age is 14.3 jears for major offenses and 16.1 years for traffic offenses. More cases occur at fourteen jears than at any other age. The records of the Los Angeles County Juventle Hall show that ages 1315 for boys and 14-17 for girls are critical periods as far as delinquency is concerned.

Tablo IX. CLASSIFICATION OF OFFENSES ACCORDING TO AGES Japanese Chinese

\begin{tabular}{|c|c|c|c|c|}
\hline Age & $\begin{array}{c}\text { Major } \\
\text { offense }\end{array}$ & Traffio & $\begin{array}{c}\text { Major } \\
\text { offonse }\end{array}$ & Trafe1c \\
\hline $\begin{array}{c}6 \\
7 \\
8 \\
9 \\
10 \\
11 \\
12 \\
13 \\
14 \\
15 \\
16 \\
17 \\
18 \\
19 \\
20 \\
\text { nknown } \\
\text { otal } \\
\text { ong age }\end{array}$ & $\begin{array}{r}2 \\
3 \\
2 \\
5 \\
3 \\
6 \\
10 \\
8 \\
5 \\
8 \\
2 \\
- \\
9 \\
63 \\
14.3\end{array}$ & $\begin{array}{r}3 \\
11 \\
17 \\
17 \\
2 \\
- \\
- \\
50 \\
16.1\end{array}$ & $\begin{array}{r}1 \\
3 \\
3 \\
10 \\
11 \\
19 \\
19 \\
27 \\
26 \\
21 \\
17 \\
4 \\
- \\
1 \\
13 \\
175 \\
14.5\end{array}$ & $\begin{array}{c}3 \\
6 \\
9 \\
7 \\
4 \\
- \\
- \\
3 \\
32 \\
16.1\end{array}$ \\
\hline
\end{tabular}

* Based on Strong's study of Juvenile Delinqueney records of Los Angeles, San Francisco, Alameda, and Fresno Count1es, op. c1t., 1933, p. 158

During the school year 1928-29, the attendance officers of Los Angeles made 55,717 investigations, as presented in Table X; among them only 117 Chinese boys and 18 Chinese 
girls were investigated. This is also true in other cities. For Instance, during the school year 1929-30, only five cases were investigated in San Francisco and nine cases in Oakland for two years (1928-30), and only four cases in Fresno during the last 23 years.

\section{TABIE X.}

INVESTIGATION MADE BY THE LOS ANGELES ATTENDANCE OFFICERS DURING 1928-1929 SCHOOL YRAR

\begin{tabular}{|c|c|c|c|c|}
\hline Cases & $\begin{array}{c}\text { Senior } \\
\text { High } \\
\text { school }\end{array}$ & $\begin{array}{c}\text { Junior } \\
\text { High } \\
\text { school }\end{array}$ & $\begin{array}{c}\text { Elementary } \\
\text { School }\end{array}$ & Total \\
\hline $\begin{array}{l}\text { Boys } \\
\text { Jegro } \\
\text { Mexioan } \\
\text { Japanese } \\
\text { Chinese }\end{array}$ & $\begin{array}{r}408 \\
863 \\
63 \\
14 \\
\end{array}$ & $\begin{array}{r}341 \\
1,871 \\
55 \\
66 \\
\end{array}$ & $\begin{array}{r}1,082 \\
5,791 \\
62 \\
37 \\
\end{array}$ & $\begin{array}{r}1,831 \\
8,525 \\
170 \\
117 \\
\end{array}$ \\
\hline $\begin{array}{l}\text { G1rIs } \\
\text { Negro } \\
\text { Mexican } \\
\text { Japanese } \\
\text { Chinese }\end{array}$ & $\begin{array}{r}207 \\
640 \\
30 \\
5\end{array}$ & $\begin{array}{r}281 \\
1,743 \\
21 \\
1\end{array}$ & $\begin{array}{r}459 \\
4,618 \\
34 \\
6\end{array}$ & $\begin{array}{r}940 \\
7,001 \\
85 \\
18 \\
\end{array}$ \\
\hline ;al & & & & 55,717 \\
\hline
\end{tabular}

* Strong, E.K., op. c1t., 1933, p. 160

It is difficult to compare the number of oriental delinquents with that of other racial groups since the custom of segregating figures into different racial groups was abandoned in Los Angeles some years ago. Although incomplete, the data in Table XI show clearly that orlental delinquents are comparatively few and that the ratio to the whole school population also is small. The "1929 Census" gives the number 
of children up to 18 jears of age in Los Angeles for the various racial-national groups; the "number of delinquents" constitute the number handled during the fiscal jear at the Juvenile Hall in Los Angeles. From the ratios it appears that the Chinese make the best showing with only 1.9 delinquents per 1,000 children up to 18 years of age. The Japanese are a close second in this respect ( 2.1 delinquents per 1,000). American families contribute over four times as many delinquents as do the Orientals; Filipinos about six times as many; Russians, Italians and Mexicans about thirteen times as many; and Negroes about twenty-five times as many.

TABIE XI.

RATIO OF DELINQUENTS TO WHOLE SCHOOL POPULATION FOR VARIOUS RACIAL-NATIONAL GROUPS IN LOS ANGELES COUNTY *

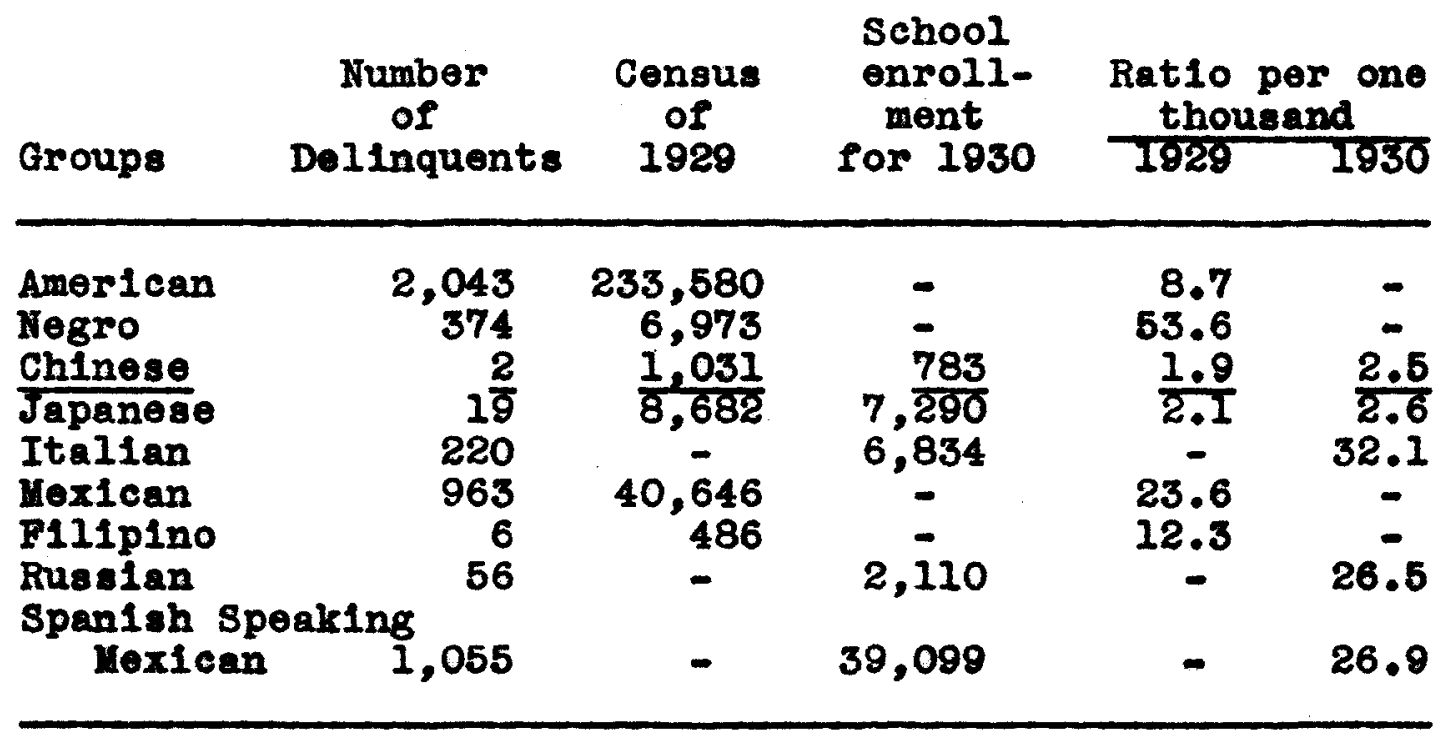

* Reports of Los Angeles County Juvenile Hall, 1929, fiscal Jear 
3. Causes of Small Humber of Chinese Crimes and Delinguencies

There are a number of reasons which have contributed to the low rate of crime and delinquency among the Chinese. They are:

$$
\begin{aligned}
& \text { a. Close home control and discipline } \\
& \text { b. General educational care by parents } \\
& \text { c. Close supervision by adults in general } \\
& \text { over the second generation } \\
& \text { d. Moral influence of chinese language } \\
& \text { schools } \\
& \text { e. Feeling of inferiority or social con- } \\
& \text { sciousness } \\
& \text { f. Social 1solation from the American } \\
& \text { b. Small number of children over } 14 \text { Jears } \\
& \text { of age }
\end{aligned}
$$

The home discipline, according to oriental custor, is generally strict, especially that over the girls. The Chinese families feol that if something reprehensiblo happens it is a disgrace not only to the individual but also to the whole family. The daughters are expected to attend to housekeeping and cooking as well as to attend public schools. They are seldom allowed to go to parties other than those sanctioned and chaperoned by church or school authorities.

It $1 \mathrm{~s}$ commonly admitted that the Chinese Immigrants have an intense desire for their children to get kmowledge and education. Scholarship is always looked upon as an honor to the family. This will of course have a great influence upon children prior to the period in which delinquency is 11kely to appear. 
Although Chinese do not have a feeling of racial preso t1ge like the Japanese, they do have a racial consclousnese. When they are in an American community, they feel something pressing and host1le. The atmosphere is heary and alien. Naturally they refrain from mingling with Americans and confine themselves to their own racial group. Since the Chinatowns are small, offenses are easily detected, and this, along with the close supervision of adults, minimizes the chances for crime.

The fact that relatively few of the Chinese population are between $12-18$ jears of age is another important factor in explaining the small total number of juvenile delinquents. And as this number increases, the number of delinquents is bound to increase. But so far the ratio between delinquents and elther total population or the population within juvenile delinquency ages has been remarkably Iow. There is some evidence that the ratio 18 increasing, but very slowly.

The last explanation, that many cases are settled outside of courts, is of an entirely different sort. Although the cases cannot be many, there is a great possibility of their existence since the Chinese are accustomed to settle their disputes by the arbitration method and to save their faces by keeping shameful acts from being disclosed. On the whole, we must conclude that as far as crime and delinquency are concerned, the chinese have made a fine record in the United States. 
v. Occupation and Economio Statua

A. Occupational Distribution

When Charles $W$. Ward, who was sent by the Interchurch world Movement to China many years ago, was asked whother he knew anything about the Chinese, he answered that he did not, but was going to China to find out whether they were a nation of four hundred million laundrymen. It is very unfortunate that the majority of the Chinese in this country are from strata which are not representative of the Chinese nation.

The occupational status of the Chinese immigrants varies in different parts of the country. In the East (In New York, Philadelphia, Boston, etc.) the Chlnese are mostis laundrymen; but they are being forced rapidly out of business by Jewish competition and well-organized, better. financed, native ateam laundries employing modern methods. In the West, for generations the Chinese have been serving as cooks around mining camps and outlying ranches. Further out, in Callfornia the Chinese have recently been employed 8 domestic servants to replace the Japanese, who are no longer in favor for that kind of work; the Japanese have become too independent to suit the ir emplojers.

In the Southern States where Chinese settled in relatively large numbers (especially in M1ssissipp1, Texas, Louisiana, etc.) most of them are engaged in the grocery

21. Bercovici, K., 으 New Shores, 1925, p. 160 
business. In Cleveland, Mississipp1, we find approximately 150 Chinese inhabitants, the largest Chinese colony in the South. Their chief occupation is the grocery business; a fow are interested in gardening. There are, at present, nine Chinese grocery stores within the city limits of cleveland, town of some 4,000 population. As there are a great many more negroes than white people in the Mississippl delta, mach of the Chinese trade at the smaller stores is with Negroes; fer modern ones are patronized by the leading citizens of the city.

Those who are gardeners own many acres of land where they raise cotton and Chinese vegetable products, such as Chinese cabbage, mustard, and beans. They anip these vegetables to Chicago and many other citles where there are Chinese restaurants. In the earlier dajs, many Chinese Immigranta engaged in agrieultural work in the Pacific States; but as the older imigrants died out and the second-generation have distributed themselves to the c1ties, they have virtualiy eliminated themselves from the agricultural field and have left the Japanese and the F1lipinos as the chier Oriental contributors to the Pacific Coast farm.

It is not easy to find the factors that have determined the cholce of such occupations as the grocery business among the Chinese immigrants in the Southern States. However, we may be almost certain that most of the Chinese in the South were brought to the Unfted States as laborers on the Southern Pacific Railroad. When the rallroad work was over they ob- 
tained work on steamships salling between San Francisco and New Orleans. In New Orleans they were offered work on interior boats plying the Mississippi. Then they began to drift Inland from the river. Probably some individual discovered he could make money maning a grocery store, and, therefore, all the others followed after him. It is of course natural that when one Chinese makes a success of a business all the other Chinese in the community will set up in the same business. This principle holds true in other places; in Mexico and Cuba all the Chinese are dry goods Importers.

There are a number of Chinese women merchants in the Mississippl delta - widows who found it necessary upon the death of their husbands, to continue the business in order to support their children. This is not found in other sections of the country. Usually the wife and children will go back to China upon the death of the husband. Most of the joung Chinese merchants today are born in America but have recelved their education in China.

Wile recent statistics are not available regarding the actual percentages of Chinese immigrants engaged in verious professions, the following report of the Commism sioner-General on the number of Chinese seeking admission to the United States by classes will give some light to the subject. 
TABIE XII.

SUMMARY OF CHINESE SEEKING ADMISSION TO THE UIITED STATES BY CLASSES

Class Alleged

De- EsAdmitted barred Died caped

0.S. Citizens

Wives of U.S. Citizens

Returning laborers

Returning merchants

other merchants

Members of Merchants' family.

Student:

Travelers

Teachers

officials

Miscellaneous

Granted or denied the privilege

of transit in bond across land

territory of the U.S.

Total
4,754 396

1,340

1,229 452

1.096

642

105

39

149

492
313

23

49

28

8

195

17

4

4

3

1

4

$110 \quad 1$

\begin{tabular}{lllll}
8,513 & 300 & 1 & 2 \\
\hline 19,267 & 1,051 & 9 & 3
\end{tabular}

* Report of the Commissioner-General of Inmigration for the fiscal year, 1924, p. 156

The following Table gives the 1920 distribution of the

Chinese and Japanese galnfully employed in 1920:

TABIE XIII.

OCCUPATIONAL STATUS OF CHINESE AND JAPANESE IMMTGRANTS

Occupation

Chinese Japanese

Machinists and Mechanics

skilled laborers

Som1-skilled laborers

Carpenters

Dowestic and Personal Service

Profeselons

Trade (Grocery, etc.)

Fishermen

$\begin{array}{rr}54 & 315 \\ 2,319 & 3,753 \\ 310 & 578 \\ 47 & 191 \\ 26,450 & 12,723 \\ 462 & 1,295 \\ 8,270 & 5,750 \\ 24 & 1,081\end{array}$

* United States Census of Occupation, 1920, pub11shed in Woofter's Races and Ethnio Groups in American Life, 1933, p. 14I 


\section{B. Changes in Occupat 1onal Status}

It is interesting to study how the Chinese entered the various sections of the country and how they shifted from one job to another. The following Table (Table XIV) reveals the effect that the quest for a clear occupational fleld had upon the ten highest vocations followed by the Chinese in 1870 and in 1920:

TABIE XIV.

CHANGES IN OCCUPATIONAL STATUS OF THE CHINESE IMMIGRANTS * 1870 1920

Miners

Laborers

Domest1c Servants

Laundry Operatives

Agricultural Laborers

Cigar Makers

Gardeners \& Nurserymen

Traders and Dealers

Employees of Railroads

Boot and Shoe Makers

$\begin{array}{rlr}17,609 & \text { Laundry operat1ves } & 11,534 \\ 9,436 & \text { Cooks } & 6,943 \\ 5,420 & \text { Waiters } & 2,766 \\ 3,653 & \text { Farm Laborers } & 2,305 \\ 1,766 & \text { Restaurant Keepers } & 1,688 \\ 1,727 & \text { Salesmen 1n Stores } & 1,606 \\ 676 & \text { Other Servants } & 1,406 \\ 604 & \text { Grocers } & 1,267 \\ 568 & \text { Laundry Owners and } & \\ 489 & \text { Managers } & 980 \\ & \text { Building Trades } & 939\end{array}$

* Un1ted States Census of Occupation, 1870 and 1920

The Census of 1870 reveals the fact that out of 1,551 people employed in making boots and shoes in San Francisco, 296 were Chinese, and out of 395 . employed in woolen mills, 253 were Chinese. The cigar trade was almost entirely taken orer by the Chinese, who numbered 1,657 out of a total of 1,811 employed in that industry. Thus in 1870, the Chinese were fitting in very well in agricultural work and in infant industries. But just fifty years later, owing to the conflict and competition with the white laborers, many Chinese 
were throw out of work and a great change was made in their occupational status. It is interesting to note, according to the Census of 1920, that boot and shoe making, which used to be monopolized by Chinese labor, was not even ment1oned in the 11st of 50 occupations, while only 61 c1gar makers appear instead of 1,727 as in 1870. This clearly indicates that white labor had regained control of the manufacturing fleld except for fish packing and frult canning, which ino dustries employed 860 and 637 Chinese respectively.

C. Financial Institutions

The Chinese Imigrants in the Continental United States have supported a goodly number of Chinese-owned-andmanaged banking institutions. However, most of these are small, some being but mercantile establishments engaged in the business of transmitting packages and money to China as a side line because it is lucrative. Some of the larger of the Chinese-owned banking institutions are: The Canton Bank of San Francisco; The Bank of China, New York Branch; Overseas Chinese Banking Corporation, in New York.

One of the most picturesque and interesting banking inatitutions on the Pacific Coast is the Chinatown branch of the Bank of America in San Francisco. It 18 a branch of an American bank wun entirely by Chinese women. Miss Dorothy Goe; the manager, passes on all loans and is the responsible head. The story was told thet many years ago, her father, Charles Gee, was hired by the main bank in San Franc1sco to handle Its Chinese accounts. He bullt up the business to 
such an extent that in 1815 the bank hired his 15-jear old daughter, Dorothy, to help him. She started with the salary of $\$ 30.00$ a month, but in three months was raised to one hundred dollars. In those three months, they took in $\$ 300,000$ in deposits, which by the end of the jear, had risen to a militon dollars. In 1923, it was decided to open up a branch in Chinatown and 4188 Gee was made its manager; and in 1928, the benk moved 1nto its present elegant and artistic quarters.

In most of the centers of Chinese population there is a Chamber of Commerce. The following list gives the location of some of these commercial bodies in North and South Amer1ca: How York, San Franc1sco, Honolulu, Havana, Trina, Mexico C1ty, Quito, Panama City, Tampico, Victoria, Vancouver.

D. Unemployment

Since 1930, the number of Chinese imnigrants has been dwindling; each day witnessed the departure of everIncreasing numbers of Chinese who were compelled to return to their homeland. The return of chinese emigrants from America as well as from other countries may be attributed largely to the world-wide economic depression and partiy to highly discriminatory governmental regulations. There has been also some Increase of European Imaigrants in the United States who are supplanting the Chinese in flelds of Industry, and an influx of Mexicans and Indians has rapidly displaced Chinese laborers. 
22

According to $\mathrm{Mr}$. Kollang Yeh, recently ret1red Chinese Consul-General at New York, out of the 85,000 Chinese in the United States, 32,000 lost employment as a result of the depression. Although no steps have been taken in the United States to ban Chinese merchants as has been done in Panama, Cuba, Peru, and elsewhere, many emplojers have preferred to employ native workers instead of Chinese.

E. Recent Relief Activit1es of Chinese Government In view of the acute unemployment conditions among Chinese Imigrants in the United States and elsowhere, the Chinese Nationalist Government has developed a relief scheme which was duly acted upon and approved by the Executive Yuen. A part of the proposed program has already been put into effect. The plan is composed of two parts, namely relief measures abroad and relier measures in China.

The object of relief measures abroad is the maintenance of the favorable position already attained by chinese settlers in foreign countries. The plan includes: minute investigation of the unemployment situation among the Chinese Imigrants so that intelligent measures of relief may be taken; organization of relief organs and bodies in the different centers of Chinese population; government loans to assist the Chinese settlers to recover their economic power; support to well-established Chinese industries and factories

22. Kwe1, Chung-Shu, The Chinese Year Book, 1935-36, p. 448 23. Ib1d, 1935-36, p. 452 
to enable them to carry on; extension of vocational education.

The object of relief measures in China is to prevent the Increase in the rank and file of the already huge army of unemployed at home by the return of the orerseas Chinese. The plan Includes: creation of sultable employment for the returned Immigrants; diversion of overseas Chinese capital and labor Into home industries; development of naturel resources; reclamation of frontier regions; program of highway bullding; establishment of factories; oncouragement of recrultment of Chinese laborers for work abroad under the supervision and protection of the Chinese Government.

The Chinese Government has promulgated also a set of regulations prohibiting Chinese laborers from proceoding abroad unless they possess employment credentials from oversoas Chinese of good standing. Offices of the Overseas Ch1nese Affairs Commission have been established in the princlpal ports of the country to direct and guide the inflow of overseas Chinese and, In case of need, to provide transportation from the port cities to thelr respective home towns in the interior.

"Happy Village" in Anhwe1, constructed. by the Commission as a refuge for indigent overseas Chinese was formally opened on June 16, 1935, by Chou Kai-Keng, V100-Chalman of the Commission for Overseas Chinese Affairs. It is situated in the heart of rich farm lands. The place was chosen partly because several Chinese who had returned from America had been 
successful in faming in the vicinity.

To remove all possibility of mis-appropriation regulations for the recelpt of donations from overseas Chinese to the national cause and the segregation of these funds have been promulgated by the Chinese Govermment. Appropriate recognition has been made from time to time for generous contributions; recently the Overseas rational Salvation Association and the Overseas Relief Assoclation of Burma were reciplents of a gold medal each for their generous donations to the nation.

F. Decrease in Remittance of Overseas Chinese

The Chinese immigrants occupy a very important position in the economic iffe of China. They have rendered very considerable help in balancing China's international trade. So the prosperity of the Chinese 1migrants bears an intimate relation to their mother country. With the recent large decrease of the number of chinese in foreign countries, Including the United States of America, there is an equally sharp decilne in the amount of the remittances from them. According to estimates of the Bank of China these remittances, which heretofore amounted to a great sum of money each jear and had been an important factor in the balancing of international payments, were reduced in 1934 to $\$ 250,000,000$.

\section{Education}

The degree of education possessed 1s a fairly good index today of social position. Possibilities of advancement, for 
olther an individual or a racial group maj be judged in terms of ability to assimilate educational advantages. Let us divide our discussion under two main divisions: namely, the education of the first-generation Chinese and that of the second-generation.

A. Educational Standards of the First-generation Chinese

Generally speaking, the educational status of the Pirst-generation Chinese is rather low. These ploneer imnlgrants had found farming or wage labor in South China unattractive and decided to soek new opportunities abroad. A few of these Immigrants may have come from the well-to-do midale class, but the majority of them were from the poor and under-priv1leged class. The educational system in Ch1na during the early days was inadequately developed and many of them had littlo schooling except what they claimed to have recelved under the old fashioned private tutorial 24 system.

According to the United States Census of 1930, the rate of 11literacy of the Chinese in the Unlted States was $20.4 \%$ as contrasted with $4.3 \%$ for the country as whole and $9.9 \%$ for the forelgn-born white. of the forelgn-born chinese ten Jears old and over, $27.8 \%$ were reported as being unable to speak Inglish; th1s Included nearly half (45.1\%) of the females and about a quarter $(25.6 \%)$ of the males.

24. Ib1d, 1935-1936, p. 453 
During recent years, the Chinese Government has cooperated with the Chinese merchants in the United States in reducing the illiteracy rate by promoting mass education and the teaching of "3,000 characters." Therefore, the situation has been improved considerably. The knowledge of English on the part of the first-generation Chinese is st1ll, however, very limited; especially among those who are over sixty years of age, and who came to America a long time ago. Many first-generation Chinese women have practically no knowledge of Inglish, since most of them were married upon arrival and very shortly afterward began to ralse children, and undoubtedly had no time to attend schools of any sort. There has been a little increase in recent jears on the part of the first-generation Chinese in public schools, espec1a11y those between ages of twenty and thirty years of age.

B. Education of the Second-Generation Chinese The Chinese immigrants, as compared with other Immigrant groups, have suffered little discrimination in sending their children to public school and have been given good fac1lities all over the Un1ted States. Although many efforts have been made to place them in segregated schools on the Pacific Coast or to send them to the regro schools in the southern States, in general the treatment has been very grat1fying.

Since most of the Chinese Imalgrants live in citles, their sons and daughters have been able to take full advan- 
tage of public school education. Practically all the Amer1can-born Chinese have recelved their education in this country - only very few have had part or all of thelr schooling in China. There 1s, however, still a dooided preference for chinese culture on the part of the chinese 1migrants and many of them are eager to send their children back to China (1f their finances permit) to get such education in order to be lojal and Ideal Chinese cltizens.

\section{The Chinese Language Sohools}

Like many non-English-speaking peoples who have come to America, the Chinese have established private schools where their children may learn the parents' native language and some of the history, traditions and customs of their native land. According to Chinese Government statist1c8, there are at present nine high schools and one hundred and nine elementary schools in the United States and 1ts possessions. All of them are privately ormed by the chinese merchants. Since 1934, the Chinese Government has undertaken to cooperate with Chinese merchants in supporting and adminIstering these schools and an annual appropriation of $\$ 330,000$ has been allotted as grants-in-ald for these schools. Many govermment educational experts have made extensive tours Investigating the conditions at these schools at first hand and elaborate reports and recommendations are being prepared and sent to the Chinese Government.

25. Kwe1, Chung-Shu, op. c1t., 1935-36, p. 455 
These language schools are divided into two different tJpes: (a) schools conducted after the regular public school hours in the form of parochial schools. These schools are merely supplementary to the public schools and not a subst1tute for them. So, while the American boys and girls are plajing games and onjoying themselves after school, the Chinese chlldren are back in school, studying how to read and write Chinese characters and learning the language of their ancestors. (b) The other type of school is the regular elementary or high sohool, with the standardized curriculum of the Chinese Government. It is a substitute for the American public school system, provided for those who have come from China directly, and who have very little knowledge of the American language. The Chinese school at Sacramento, Callfornla officially named "Chung Wah Public School," is a typical example of such a school. The school now owns its bullding and property, bullt by Chinese merchants in Callfornia under the leadership of Mr. Fong Yao Pu, Chalman of the Sacramento Chinese Chamber of Commerce.

The teachers in these language schools are graduates of public Senior High Schools or Normal Schools in China who have had one year's training under the Nat1onal overseas Affairs Commission of the Chinese Government. In accordence With the California State Law (offective June 30, 1921), these teachers must also pass an examination in Amerlcan

26. Kwe1, Chung-Shu, op. c1t., 1935-36, p. 460 
history and show abllity to read, write and speak English. Each school was required to secure a pernit from the superintendent of Public Instruction which could be withdrawn at anj time if the law was broken. These schools are found not only In California, but also all over the country in cities where there are concentrations of Chinese population.

Judging from the survey made by the Chinese Consulate in San Franc1sco and published in the chung Sa1 Yat Po, about 65\% of both sexes of American-born Chinese have attended these schools for an average of two jears for the entire group. In other words about one-third of the chinese ch1ldren in Cal1fornia have not attended these schools at all and the remalnder have spent about four years in them.

The arguments in favor of the Chinese-language schools are as follows:

a. The language school helps the parents and chlldren to understand each other's problems better; with the result that parents can keep the children straight on the moral side and give them advice. In other words, the common language tends to bind the first and second-generations more closely together.

b. The language school helps to eliminate the 1lliteracy among the Chinese Immigrants. Those who did not have much education in China and are not able to go to the American public school on account of language difficul-

27. Strong, E.K., 오. c1t., 1934, p. 127 
t1es can be enrolied in these schools and enfoy educational advantages.

c. The language school serves as a unifying social organization in the community. Among Americans the Boy Soouts, Girl Reserves, religlous groups and other similar organizations develop social and moral ideals and standards. In many Chinese communities, the language school is the dominant factor in these respects. Here the children are taught, In addition to the Chinese language, the moral and cultural principles underlying Chinese civilization and the common practicea of American 11 fe.

d. Knowledge of the Chinese language, especlally the Kandarin, is helpful in many cases, in securing work. (Mandarin is the official Chinese dialect). - Finally, the language schools raise the self-esteom of both generations of Chinese. In a country where they have been looked down upon and 11l-treated, it 18 natural for them to develop inferiority complexes. A study of what China stands for and what she has accomplished, a kmowledge of her literature and art, an appreciation of her ancient culture and recent advancement, all tend to increase the student's respect for his race and so for himself. Such study causes the young people to appreclate their parents' background and point of viev and so decreases the too-numerous opportunities for misunderstanding and conflict.

All these advantages may be conceded and jet there may 
remain the practical objection to these schools on the ground that they are attempting the well-nigh impossible, as far as the majority of Chinese are concerned. There is no question but that the superior child could successfuliy carry on the work required in the public school and st1ll find time to leam the Chinese language. But the ovidence seems to be quite conclusive that the average and inferior child cannot do this. Although there has been no study made so far along this line, there are clear indications that fer Chinese are mastering the English language to such an extent that they will not be handicapped in mingling with the white population, and the evidence seems to be equally clear that they are not obtaining a real mastery of the Chinese lan28

guage. Smith finds that orlental chlldren attending forelgnlanguage schools make lower scores on reading and general Inglish tests even when palred with chlldren of equal intel118ence scores:

"Intelligent study of the errors made by oriental children in reading seems to point toward a definite confusion of Orientation among those children that attend two schools, which 1s probably a factor in their delayed progress in reading. Children may not be quite so disturbed by the different reading directions if they do not enter both schools at the same time."

On the other hand, those who attend the Chinese schools alone are segregated entirely from American community 11 fe. It is also true that not all these schools are conducted in

28. Smith, M.E., "The Direction of Reading and the Effect of Forelgn-Language School Attendance on Learning to Read," Journal of Genet1c PsychologY, Vol. XI, No. 2, June, 1932, p. 449 
the modern scientific manner. Some of them are st1ll under the strong influence of the old private tutorial system. They are called "the new-type school" in name, but in actual practice, little change and improvements have been achleved. Such wore the Pel Ying Acaderny in San Antonio, Texas, and many schools in California. The inefficiency of these schools is due largely to the following defects: (1) loose and unhealthy organization, (2) too littlo administrative power and lack of control, (3) unsatisfactory curriculum, (4) no cooperation betweon schools. In fact clannishness and jealousy were the dominating att1tudes. In spite of all these defects, the following outstanding achlerements during recent years have been made: (1) the prevalence of the use of Mandarin for class instruction, (2) emphasis on vocational education, (3) normal courses in the girls' schools aiming to be of service in the adrancement of primary education, and (4) the development of high school education. So on the whole, the Chinese language school for Irmigrants has entered upon a new age due to the intensive interest of the Chinese Government, which wants to encourage international cultural cooperation and to give the overseas Chinese a sense of nationalism.

2. Some Recommendations Regarding the Acquisition of the English and Chinese Languages

As it has already been polnted out, some knowledge of Chinese appears desirable for all of the secondgeneration Chinese. It is needed in order to insure proper 
morale within the famliy and the Chinese group. It 1s this relationship which is seemingly so largely responsible for the low rate of juvenile delinquency reported in the previous section. Furthermore, the second-generation Chinese need to know of the achlevements of their race, 1ts h1story, 11terature, art and recent economic development. They need th1 knowledge, among other reasons, in order to offset the feeling of inferlority which any second-generation individual is apt to acquire in a now onvironment. The Chinese language, however, is an exceedingly difficult one to acquire. For that reason, it would seem best to plan that the rank and file of the second-generation should acquire real facility in English and only sufficient Chinese to meet the needs of ordinary family and group activity. The more intelligent and Industrious may, In addition, acquire a far better grasp of the language of their ancestors. But this will necessitate more time than can be given to the subject during grammar school days.

In the light of these considerations, it seems to the writer that the best possible solution is to be obtained in some such way as this:

First, the work of the Chinese language schools should be continued. In this way the chinese language and culture w11l be transmitted to the second-generation. But the conduct of these schools should be controlled in the light of developments to be brought about as soon as possible, as outlined below. 
Second, study of Chinese should be introduced Into cortain junior or senior high schools as a substitute for Frenoh or German. This will provide instruction at the age when most of the second-generation drop out of the language schools, and would make possible more advanced instmuction, which is badly noeded. It will also, give an opportunity for some whites to study the language, which from many angles seems to be desirable. (The writer knows several m1ssionarles' ohlldren who have studied the Chinese language In China and who asked the university where they studied in America to accept their Chinese as the modern language to meet the requirement for their college degree). Th1rd, a course in the geography, history and economle development of China and Japan, with proper consideration of their art and literature should be given in certain high schools. Such a course is badly needed for the best development of American citizens of Chinese ancestry and it is equally desirable for other c1tizens growing up on the Pacific Coa'st. The writer has studied American geography and history since his early school days in the funior high school in China.

Fourth, the present courses in American Universities which deal with Chinese language and culture need to be strengthened materially. There are almost 500 courses offered in some 200 Amerlcan colleges and universities

29. Bulletin of the American Counc1l, Institute of Pacific 
which treat China either as a major subject or as a subject that occuples a significant portion of the course. But a majority of these courses are given in institutions on the Pacific Coast in the departments of political science, soclology, and history and only a fow colleges are offering courses in the Chinese language. One is offered at Stanford OnIversity, eleven at the UnIversity of Callfornia, and four at the University of Washington.

Such recommendations appear to be about as veluable as any which can be presented from the standpoint of alding the Chinese Immigrant children to earn a satisfactory living in this country. Success in many occupations is dependent upon the minimizing of differences. Mastery of good English is Within the power of the Chinese-Americans, but the educatlonal system of the country should be adapted 80 as to ald them in this respect.

VII. Press and Public Bodies

The newspaper is one of the directing forces of modern culture. Hence the cultural standard of a city or racial group can always be judged by 1ts journalistic enterprises. Following is list of the Chinese newspapers publishod in 31

forelgn countries:

30. Carter, E.C., China and Japan in our University Curricula, 1929

31. Kw01, Chung-Shu, op. o1t., 1935-36, p. 459 
TABIE XV.

CHINESE NEWSPAPERS PUBLISHED IN FOREION COUNTRIES

\begin{tabular}{lr} 
Locality & $\begin{array}{r}\text { Number of } \\
\text { Newspapers }\end{array}$ \\
\hline The Malay Peninsula & 8 \\
Burma & 2 \\
India & 1 \\
United States of America & 18 \\
Java & 5 \\
Cuba & 3 \\
Panama & 3 \\
Peru & 2 \\
Jamalca & 1 \\
The Philipplnes & 4 \\
Canada & 4 \\
Australla & 4 \\
Indo-China & 3 \\
Africa and Marit1ous & 4 \\
Hongkong & 12 \\
Slam & 7 \\
Celebes & 1 \\
Sumatra & 2 \\
& 74 \\
&
\end{tabular}

Out of the 74 ChInese newspapers published abroad, 18 are published in the United States and 1ts territorial possessions.

Hg Poon Chew is the father of Chinese joumaliam in America. He arrived at San Francisco in 1881 when he was only fifteen years of age. He soon found a job as a housem boy and was permitted to go to school at night. In 1883, ho became a Christian and entered the San Francisco Theological Seninary from which 8 chool he graduated in 1892. In the same Jear, he was ordained and became pastor of the Chinese Presbyterian Church at San Francisco. It was not long, however, before he came to feel that the opportunities in the 
minlstry were limited; and accordingly he commenced to seek activities of a wider scope in which to serve his peoplo. The 1dea of a newspaper appealed to him since there was no Chinese newspaper in America at that time. In 1898, w1th the financial cooperation of a for frionds, ho establishod In Los Angeles the Wah Me1 Sun Po, a weekly; and in 1900 in San Franc1sco the Chung Sa1 Yat Po, the first Chinese daily In America, which, with the exception of a week after the San Francisco earthquake and fire, has been in continuous publication ever since. Thus this courageous spirit led the way which others later followed. In 1912, the University of P1ttsburgh conferred upon him the degree of L1tt. $D$. in recognition of his ploneering work in journalism among Ch1nese in America.

There are at present 18 Chinese newspapers, published in the following American citles: New York 6, Chicago 2, San Francisco 5, Honolulu 5. They are:

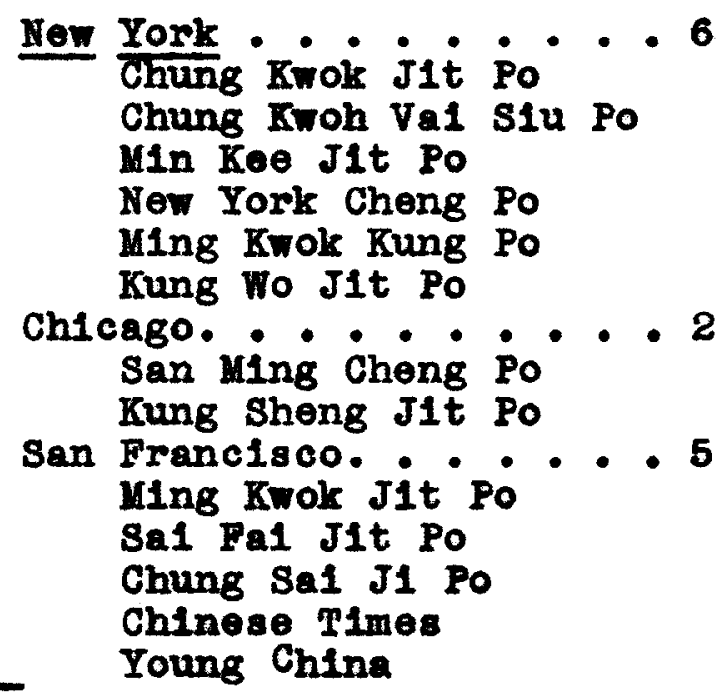

32. Shepherd, Charles R., "Pather of Chinese Journalism in America," The Chinese Christian Student, S1lver Anniversary Builetin, 1934, p. 30 


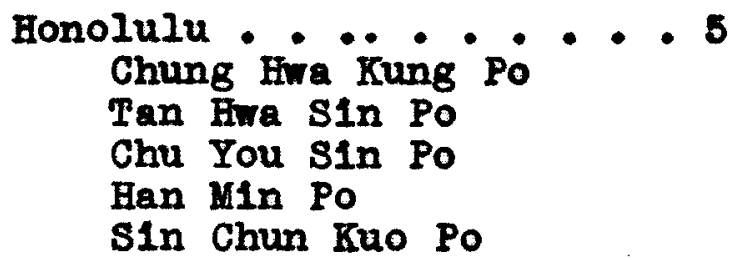

Each of these papers has an average circulation of 4,000 coples, serving not only Chinese inmigrants in the Continental United Stater but also in Canada and South America. All these papers are published in the Chinese language; Chung Era Kung Pao of Honolulu, publishes an Inglish and Chinese edition. The purpose of these papers is to maintain contact with the old country and adapt the aliens to the new comwunity. Some of these papers were founded by political leaders who were exiles in this country. They used the press to preserve the nationalistic spirit of the Immigrants who expected to retum home to participate in the Hationalist Revolution. So these papers are usually generously supported by those Chinese imigrants who are intensely patriotic. But the difficulty of getting up-tomate and reliable information from China, coupled with the impatient attitude of many overseas leaders with the policies of the Nat1onalist Government, make it hard for these papers to help in developing a sound and intelligent viewpoint on the part of their readers. Thus instead of promoting unity in political thought and outlook, many of tham unfortunately caused unnecessary misunderstandings and dissensions in the Chinese colonies.

The contents of these papers are not completely given 
to problems of China; some of them discuss trade, comerce, and other Items of interest. Space is usually allocated among five major divisions: (1) American news, (2) world news, (3) home country news, (4) group life and interests, and (5) editorial features. The first page 1s usually given over completely to news 1tems. A number of papers devote the first and second columns to "world news," the last two to Amerlcan news and the middle three colums to news of the homeland.

The second page is given over to editorlals, very often on American subjects, and to feature stories which are more I1kely to deal with the life and problems of the home country. All avallable space on the third and fourth pages is devoted to group Interests, such as reports of societies, letters to editors, local reports, and notices.

yost of these papers are, however, predominantly radical. This tendency is probably due to the fact that practically all of them serve labor groups and are naturally friendly to the cause of labor.

The "Americanization" of the Chinese press is 1llustrated by the Increased use of press matter from American sydicates, Including sporting news, feature storles, cartoons, and comic strips. The characters in those "comics" most popular in America seom to have failed to make an impression upon the Chinese-born readers. Chinese editors show a decided preforence for picture strips embodying the spirit of adventure; "Tarzan of the Apes" has been widely 
used.

Political cartoons are winning their way into these chinese papers; most of them carry syndicated American or imported cartoons. On the whole, the chinese treasures his om language as being not only his counselor and friend but also that intellectual ferment which makes it possible for him to adjust his life to the complicated structure and environment of America.

Other cultural enterprises managed by the Chinese imengrants in America are: the Chine Institute, the Chinese Four Arts' Association, and many others. The China Art Club gives an annual exhibit at the Club's gallery at 175 Canal Street, New York City, New York. According to a survey of public bodies among overseas Chinese made recently by the Comision Por Overseas Chinese Affairs of the Chinese Govermment, there are some 756 organizations, 72 of them in the United States - among which 33 are professional organizations and 39 social organizations.

VIII. Religious Affiliation

Since the Chinese came from a country where Buddhian and Confucianism are the dominant religions, the firstgeneration Chinese usually prefer to remain as Buddhiats or Confucianists. But the second-generation Chinese clearly tend to transfor thoir allegiance to Christianity. This tendency is probably due to the fact that many churches in

33. Kw०1, Chung-Shu, op. c1t., 1935-36, p. 454 
the larger cities have sunday school classes for Chinese chlldren. Chicago has eleven Chinese Sunday Schools and more than 500 Chinese chlldren have enrolled in these sun34 day School classes.

Preference for Christianity instead of Buddhism or Confucianism is associated with better education, better use of the English language, urban life, and greater ownersh1p of homes or businesses. When there is a Buddhist and a Christian element in a Chinese community, it usually appears that the Christian is more Americanized than tho 35

Buddhist element.

Perhaps the most outstanding feature of the religlous ilfe of minority groups is the tendency to organize separate churches for these groups. All over the United States there are many Chinese Christlan churches headed by Chinese native pastors. In Seattle, for instance, there are two Chinese churches, Presbyterian and Baptist. The latter 1s large, and well-oquipped and maintains an active program with night school and Dally Vacation B1ble School. The newly ordained pastor is a graduate of the University of Shanghal and has had training at the southwestern Baptist Theological Seminary at Fort Worth, Texas. At Chinatown In San Francisco, there are nine denominations working

34. Lee, Ph1l1p, Yearly Calendar and Yembers' Directory, Chinese Christian Union Church, chicago, IIIInols, 1937 , p. 6

35. Tentat1ve Findings of the Surver of Race Relations, 1925, p. 3द 
among the Chlnese - the Presbyterlan, Congregationalist, Method1st, Bapt1st, Independent Bapt1st, Cumberland Presbyterian, Salvation Army, Episcopalian, and Roman Catholic. In addition to these denominational forces, there are also a strong well-equipped Y.M.C.A. In a commodious building, and a Y.W.C.A. which is a perfect gem of Chinese architecture. Here also is located the famous Presbyterian Mission Home presided over by M1ss Donaldina Cameron whose thrilzIng adventures in combating the Chinese under-morld are recorded by Carol Green Wilson in Chinatown Quest. She has rescued from slavery not less than fifteen hundred girls in twenty years. No wonder Chinese high-binders, (see Chapter IV) call her Fa Hu Qua1, "Barbarian Dev1l," while those who know and love her call her Lo Mo, "The Little Mother." The work of the Y.W.G.A., presided over by Miss Rose Chew, is particularly appealing. It enrolls 550 members but serves many others, 1ncluding 150 children, 80 of them in their teens. One of 1ts valuable services is to give recreational opportunity, to Chinese girls who have very few privileges in this direction and who, as a result, tend to become In-grown and clannish. "Many Chinese girls, also," says Miss Chew, "have never had an opportunity to go into American homes and so tend to pick up only the more superficial aspects of American 11fe." It may surprise American

36. "High-binder" means a member of an organized band of Chinese criminals in the Chinese quarter of an American city who may be hired to commit assassinations or other outrages 
readers, however, to learn that "when the Girl Reserves Conferenoes have discussions about boy and girl problems our girls don't know what hip flasks arel when we have parties we don't foel that wo have to chaperon them." This is in line with the testimony of the steward of a seattle club sometimes rented out to parties, that the oriental young poople were the most orderly of all the groups that came and that they left no whiskey bottles behind.

Not in Chinatown itself, but serving it, is the Chung Mo1 Home, conducted by Dr. C.R. Shepherd of Berkeley, Cal1fornia. This cares for about sixty under-privileged chinese boys who otherwise would be adrift in the world. The boys attend the Berkeley public schools. An excellent composite plcture of a Chung Me1 boy is to be found in Dr. Shepherdis very readable story of Chinese boy 11fe, Lim Xik Choy.

In Los Angeles much good work is also being done. Vigorous services have been carried on by the Baptists, the Methodists, the Reformed Church in the United States and the Episcopalians. The Christian work among the Japanese In Los Angeles, however, is more advanced than that among the Chinese. But Christian work for Chinese has not been confined to the Pacific Coast. Many things can be sald about the work of Miss Mabel Lee, Ph.D. from Columbia, who has given up many attractive positions to take up Christian work in Chinatown in New York City. She now has two hundred volunteer teachers helping in the Chinese Baptist Center. The Presbyterians also have been active there and 
and have promoted several centers for Christian work among Chinese. The last Oxiental M1ssions Directory (1936) 11sted a grand total of 446 places where religlous work of some sort was being carried on for orlentals, 330 in the continental Un1ted States and 116 in Hawall. of the 330 in the Continental United States, 182 wore on the Pac1f1c Coast and 148 were scattered throughout the country, 29 in New York, 26 In Massachusetts, 15 in Pennsylvania. Many of these are doubtless very small, perhaps not more than a Chinese sunday School or evening class in many eastern c1ties. Home M18slons Todar and Tomorrow, published in 1934, 11sts 294 misslonary workers among 16 denominations not including those who are working in Hawail.

Divided racially, there are 180 centers of Chlnese work, 59 of them on the Pacific coast of which 32 own their own property. The Japanese come next with 127 centers, 101 of them being on the Pacific Cosst, 39 oming their own property. Twelve are Korean, all in California, ten are Filipino, all but one on the Pacific Coast, and one in Hindu, a Baptist work at Elcentro, Callfornia.

In Chicago there is a UnIon Chinese Christian Church, located at 2301 South Wentworth Avenue, in the heart of Chinatown. The church was organized in the jear 1915, under the leadership of Rov. Frank L1, who is now the Ambassador of the Chinese Hational1st Government to Denmark. Before that time, there were sunday schools in the city but the members multiplied so rapidiy that they decided to organize 
the1r own church. In 1924, they bought their own church building and already ten ordalned ministers have served as pastors of this church. The present program of work of the church is as follows:

\section{Sunday worshlp services}

Graded Sunday School with all departments

B1ble class and ovangelistic meotings

Chineso language class

M1d-week prayer meeting

Women's Missionary Soolety

Boy scouts

Girls Gleo Club

Dress-making Club

Boys Clubs

Sering Class

Church cholrs - giving irregular sacred concerts

The church has at present a membersh1p of 150,80 of whom are resident members. Recently, the Church has been convinced that a more adequate church structure is urgently needed and desires to erect a new church building in 1939. Onder the excellent leadership of their present pastor, Rev. PhIlip Loe, $\$ 5,000$ have already been raised and their final gool is $\$ 50,000$.

The Home Mission Board of the Southern Bapt1st Convention has recently taken up work among Chinese living in the M1s81ssippi delta. In 1933, Pastor L1 Shu Yen was appointed as Chinese missionary to this largest Chinese Colony in the South. In addition to his duty as missionary, he is also helping to establish a school for Chinese chlldren. (See Chapter IV).

While the Protestant churches are interested in misslonary work among Chinese Imigrants, the Roman Catholic Church has also taken an interest in the, work, especially 
In the Pacific States. In San Franc1sco where nearly 12,000 of the 75,000 Chinese Immigrants 1ive, we find a Catholic parochlal school for Chineso children. The school has at present an enroliment of $400 \mathrm{ChInese}$ boys and girls, most of them American born. A third of them are Catholics when they enter rindergarten. By the time they reach the 8th grade, another third have been converted. These boys and girlo spend flve hours a day and nine jears of their lives in learning to read, pray, sing in the Cathollo manner under the tutelage of black-clad nuns of the st. Joseph Order. Mention must be made of the three great International Houses which have recentig arisen on the campuses of columbla UnIversity, the University of Chicago and the University of Calffornia. While not religlous institutions, they are great centers of inter-racial understanding, and are largeig patronized bJ Orientals.

Turning now to questions of future polley and development, the question arises as to whether there should be separate churches for Chinese at all or whether they should be merged into the regular churches of the American communitJ. As with all immigrant peoples, there seems to be a temporary place, at least, for the racial and national group churches, provided they are safe-guarded in certain ways.

It is generally agreed that the separate Chinese church must continue for a generation or so, since these churches can minister to the older people as an American church could not, and also, if conducted with sufficient insight into the 
needs of the rising generation, they may provide for the Joung people of the second and third generations opportunit1es for leadership and self-expression which they could not obtain in the ordinary American churches. There are, howover, many improvements to be made in the present scheme. The following are some of the suggestions.

First of all, as in so many other phases of Protestant work, wasteful and ineffective competition should be elim1nated. Chinatown, San Francisco, for example, 1s altogether too competitive. Too many denominations work in the territory and among the same poople. Here we have something to learn from the Roman Catholics. While they have come into the orlental work late in the day and they have by no means so many institutions as the Protestants, those which they do have are very strong, well located, well housed and well manned. It is time to rise above denominational rivalries and think constructively in terms of a united Protestantiam and the welfare of the oriental.

A second question which may well be ralsed about the Chinese churches is as to whether they are not in danger of what the soclologists would call "cultural lag," that is, of remaining too first-generation-minded in the presence of a situation where strategy calls for making the strongest kind of a bid for the second-generation. One sees this in the use of language - the most important services tend to be In Chinese, although English is the language of the second-generation. An American addressing an Oriental 
audience on the Pacific Corst soon finds that they follow him very well, laugh at his jokes and respond to his appeal. The need of interpretation will grow steadily less. But it is not merely language; equally dangerous is a lag in 1deas and attitudes. One wonders if, possibly, too large a proportion of the ministers have been trained in China.

The third question 18 the matter of training of min1sters. Too many Chinese ministers serving Chinese churches have little scholastic and theological training. The result 1s that many American-born Chinese professional men are not getting anjthing religlous out of the church services, because the pastor's thoological ideas are too old-school and his preaching is either below the intellectual level of the second-generation or $1 \mathrm{~s}$ just aimed at the children or the h1gh school group. Many churehes have falled to hold the young married people, often college educated, since they do not have up-to-date preaching, book reviews and discussions of living 1ssues. There has been, however, some progress made in this direction during recent jears. The Baptists report that of their fifteen pastore five can preach in English; ome of them are graduate students at the nearbj universities. The young people in some churches are organlzing themselves vigorousiy and ploneering their own way under the leadership of joung, educated pastors. Another thing needed in this whole Chinese religious situation is the establishment of closer contact with the American churches. If the chinese are not to develop into 
a separate caste, it must be the Christian churches of Amer1ca that lead the way to prevent 1t. This can be done in two ways.

First, where there are enough Chinese in the community to have churches of their own, great responsibllity rests upon the American churches to keep the paths of fellowship open between them. They can welcome and entertain young Chinese in their homes. Such hospltallty would help to cause many barriers to crumble, particularly if it were not insisted upon or untactfully demended, but simply assumed as a matter of course. "One of the great indignations of my life," sajs Pearl Buck "was to find certain women in Christian churches in America who would give money and time to a forelgn mlssionary soclety for work among peoples ten thousand miles away but who would not open the doors of their homes to persons of other races in their own cities, strangers and forelgners in America. What is the use of preaching Christ abroad when we deng Him by such acts as these at home?"

Second, churches located in areas where Chinese are few have opportunity to bring these poople right into the warm glow of American church 11fe. Do not put them all together in a special class; that is exactly what they do not want. Mix them in with everybody else. Treat them exactly as you would all other human belngs and you'll Pind how responsive and appreclative they are. 
IX. ChInese Imigrants and Nat1onal Reller

The Chinese Immigrants in general show much genuine foeling of lojalty and patriotism toward their mothercountry. While it is impossible to give complete story in th1s monograph, a few 1llustrations will suffice to show how lojal the overseas Chinese are. For Instance, during the Shanghal hostilities in 1932, the Chinese in a small Canadian town contributed as much as $\$ 10.00$ per person, one prominent doctor giving $\$ 2,000$ ! The Chinese comrunity in Portland, though less than 2,000 in number, spent onormous sums of money during those days to train native-born chlnese aviators. For this purpose they even purchased a special plane. Subsequently several of the men trained have been sent to Europe for advanced studj. Todaj a number of them are helping the National Government of China in building up a modern air force.

Shortly after the beginning of the struggle between China and Japan In August, 1937, the Chinese all over Amer1ca, from New York to California, from Canada to Mexico, plunged themselves into all kinds of patriotic activities the chief interest being the huge campaign for the "National Emergency Fund." The campaign is divided under two main divisions; namely, the war fund and the relief fund. The Consolidated Benevolent Association was organized to solic1t funds among ChInese Imigrants throughout Continental United States. Many clties have responded generously. The Chloago Chinese alone have ra1sed $\$ 850,000$ since September, 1937. 
250 Chinese in St. Louls have ralsed $\$ 120,000$, an average of $\$ 400.00$ each. Chinese Immigrants in the south, M1ssissipp1, Arkansas, Texas, have placed contributions on a compulsory bas18. Fach ablo-bodied man was assessed $\$ 6,00$ each month and each store owner $\$ 12.00$, with large stores expected to give more.

Thus by December, 1937, Chinese Immigrants in Continental United States had raised a total fund of over $\$ 4,000,000$ to help fight China's undeclared war with Japan. Nearly forty percent of this amount was raised in San Francisco. The first-generation Chinese have shown much enthusiasm in promoting these activities. The American-born Chinese have also participated in ralsing war rellef funds in order to help the stricken refugees and non-combatents throughout the war areas of their ancestral land. Although they are citizens of the United States, yet culturally and racially they are Chinese. By right the American-born should be neutral because the American Government pursues a policy of neutrality in the Far East; but when neutral1ty is not neutral, how can they support the policy of the United States. In enforcing one section of the Neutrality Act the Government of the United States forced the frelghter Wichlte to dump in Californie the planes which were bound for China and then allowed it to proceed to Japan with a load of scrap Iron which was turned into enough ammunitions to blow a Chinese viliage to pleces. How can one be noutral when neutrality works the wrong way?

37. The Chinese Christian Student, Vol. XXVIII, Numbers 4-5, Harch-ApriI, 1938, p. T 
In September, 1937, a group of Chinese girls in San Antonio, Texas, started a drive for funds and clothing for ald of Chinese refugees in the war-torn districts. This campalgn has spread to many southern cities, including Birmingham, Alabama; Shreveport, Loulsiana; New Orleans, Loulsiana; San Antonio, Houston and Galveston, Texas. Permanent local headquarters wero established in Mob1lo, Ala38 bama.

The overseas Chinese have never falled to respond with generous contributions for relief work whenever there was flood or famine in China. A friend of the writer who Iives in Honolulu estimated that during the last fifteen jears the Chinese in the territory of Hawail must have remitted at least $\$ 200,000$ for various relief activities in China. So, in conclusion, we must recognize without hesitam tion that the Chinese immigrants in Continental United States are enterprising people who have become successful in spite of seemingly insurmountable obstacles. Unl1ke the Europeans in the Oriental countries these "Chinamen" have never relied upon gunboats or extra-territoriality in competing with the local population. They have been able to stand on their own feet in spite of language difficulties, much social discrimination and other adverse conditions. Their success was chlefly due to thelr strong character, business acumen and diligent work. The following are a few

38. Shreveport Times, November 30,1937 
of the noble, worthy examples:

Mhere is a leading restaurant owner in Honolulu, who having saved his earnings on a plantation farm, ventured into the chop suey business with a small capital of $\$ 275$. Through clever planning and hard work he has today developed and owns the most popular and most luxur1ous rendezvous in all Hawa11, estimated to be worth nearly $\$ 200,000$.

"Then there is the man who once had a small dry goods store in Sacramento but during the last two decades he has assiduously bullt up 38 others in varlous c1ties of the United states, and has now organized them into a national system of dollar stores.

npey sell to the white trade and employ white girls exclusively as salespeople, but with chinese management. The stores are clean, light and well located. The merchandise is low in price and displayed according to the most approved methods of the modern 5 and $10 . \mathrm{Be}$ hind the stores are the factories where they make the dresses, aprons, overalls and many other things they sell. Here they give employment to hundreds of Chinese. True, there are criticisms 28 to the wages and hours, but let us hope that the better codes and standards which seem to be growing up in industry will take care of this. Meantime, here is an oriental enterprise at all events, which has broken through the economic barrier." 39

39. Palmer, A.W., op. c1t., 1934, p. 146 


\section{Chapter IV}

SOME VITAI PROBLEMS AMONG CHINESE RESIDENTS IN AMERICA

(1) Racial Friction and Accommodation

(2) Occupational Opportunit1es

(3) Some Vital Social Problems

(4) Problems of Education

(5) Moral Problems in Chinese Communities 
Chapter IV

SOME VITAL PROBLEMS AMONG CHIMESE RESIDENTS IN AMERICA

Bearing in mind the facts presented thus far, let us now turn our attention to the main theme of interest in this study - namely, some of the vital problems which confront the Chinese irmigrants today. Generally these difficulties and problems fall into five fairly distinct but not unrelated groups: racial, occupational, soclal, educational, and moral.

I. Raclal Friction and Accommodation

One cannot overlook the fact that even today one racial group can treat a minority group very shamefully. Within short period of time, Filipinos have been kilied in California, Chinese driven out of Mexico, the Jews treated abominably in Germany, and hundreds of thousands of Chinese living in China killed by the Japanese. Racial prejudice has always existed and probably always will. It is not at all peculiar to Caucasians. Stratton, for example writes:

"It is found among people ancient and modern; great and small; savage, barbarian, and civilized. A survey might disclose peoples who have never felt 1t, who feel only sympathy with all allens or at least no aversion, but this seems improbable."

There 1s, and has been for many jears, a very strong racial discrimination against the Chinese in America; not

1. Stratton, G.M., Soc1al Psychology of International Conduct, $1929, \mathrm{p} .42$ 
so much against the educated and cultured group of 2,000 Chinese students, but mostly against the large group of Chinese merchants and leborers, varying from perhaps 150,000 at one time to about 75,000 at the present. But in spite of the fact that both groups have suffered under economic and social discrimination, they have had a very large share in the development of the "New China" by providing for the leadors of China large financial support, and by furnishing a great many of the economic and political 1deals adapted by these readers.

A. Factors that Cause Racial Prejudices What, then, are the factors that cause race friction? Race prejudice is based first of all, upon the fact that differences exist between the two races, a fact which always causes a feeling of strain and uncertainty. Race antipathy is based often on a difference in cultures. All customs save our own seem to be a blt inferior. Americans laugh at Chinese because they write from right to left and Chinese think occidentals queor for the reverse reason. The second factor is that the readjustment to a new situation, involved in coming into contact with a race difm forent in appearance and customs, is unpleasant to those with established habits. An American once asked a Chineso why Chinese wore his Iingernalls long, and the Chinese replied by asking him why he wore that white board around his neck. Custom has the atmosphere of the right, the superior way. All who do otherwise are inferior. "No creed, no

2. Sumer, Wm. G., Folkways, 1907, p. 61 
moral code, and no scientific demonstration can ever win the same hold upon men and women as habits of action, with assoclated sentiments and state of minds, drilled in from childnood."

Racial prejudice is, furthermore, due to the tendency to develop national stereotypes on insufficient evidence. In other words, our first unfavorable reaction to the member of another group tends to become the stereotyped reaction to all members of that group. The unfamiliar and new is interpreted by each Individual in terms of his own experience. Thus the reaction to the unknown is partly an expression of the unknown itself and partly, if not mainly, an expression of the individual's background. One of the ways of analjzing the character of individuals is to note their reactions to similar incidents. The honest and upright may well interpret the incidents on the basis of honest behaviour; the dishonest man sees crookedness even where none exlsts.

"For the most part we do not first see, and then define. We define first and then see. In the great blooming, buzzing confusion of the outer world we pick out what our culture has already defined for us, and we tend to perceive that which we have plcked out in the form stereotyped for us by our culture." 4

Thus, the strange is interpreted in terms of the fam1l1ar, but also it is usualiy so interpreted in terms of one's experlence with 1t, which tends to condition all subsequent

3. Weatherford and Johnson, Race Relations, 1934, p. 69

4. Lippmann, Walter, Public oplnion, 1922, p. 81 
behavior. One sales manager, for example, would not hire men with red heir. The first one he employed had been a fallure. Therefore, as far as he was concerned, all redheaded applicants would be failures. It is this tendency to form a generalization upon Insufficient ovidence that makes stereotypes such dangerous elements in social relations. stereotyped reactions are made to certain signs or symbols. Our language is filled with just such cues which set of elaborate sentiments, bellefs, judgments, or trains of thought. It is in this way that stock phrases, shibboloths, slogans, and the like become so effective in gaining the desired response through advertising, propaganda, and the utterances of political spellbinders. An example of how easily one may respond unfavorably to a term which actually characterizes oneself, but without appreciating this fact, is given by Katz and Allport in their measurement of snobbishness at Syracuse UnIversity. In Table XIX are given the percentages of students willing to admit certain groups to their fraternities or rooming houses. Very few state they would admit "loafers" or "students lon in intelI1gence." Such terms are "unpopular stereotypes," notwithstanding the fact that loafing itself may be fairly popular. Although many students indeed must have been of only mediocre intelligence, and though many were ldlers, many of these very students refused to recognize dullards or losfers

5. Katz, L.D., and Allport, F.H., Students' Attitudes, 1931, p. 145 
as belonging in "their set." The prejudice is thus against an abstract name, rather than against individuals in the concrete. It is standard upheld by lip service, though unreal in fact, which is asserted in order to preserve one's personal pride or self-respect.

The same principle holds true in prejudices against the Chinese. Once prejudice has been established toward a single Chinese, for example, the differences in h1s appearance or manner become signs of membership in the Chinese race and result in stereotyped reactions. When any other Chinese is encountered, the peculiarities of his race set off the sterootjped reaction. The second Chinese is not an individual first - and Incidentally a member of the Chinese race; he is a "Chink" first, endowed with all the undesirablo attributes of the stereotjpe, and only incidentally a particular individual. Prejudice is just what the word 1mplies, the result of pre-judging a person or group. The general meaning of the term is that of opinion, favorable or hostile, based on prepossessions, and therefore blased or unreasonable.

There is still another factor which contributes to race prejudice. Each individual prefers to be himself rather than anyone else. The world radiates out from each of us. Our views, standards, bellefs are the true ones; what others hold to are strange, 11 logical, wrong. As each of us grows older he extends his ego out to include more or less his own family, his friends, his acqualntances, his own social group. Similarly, he comes to view their attitudes and generallza-

6. Strong, E.K., The Second-Generat1on Japanese, 1934, p. 107 
tions as more or less h1s own. And he views with distaste or antagonism those who fall outside his own group, insofar as they differ from him. It is because of this that, when our own status is affected economically or our feeling of superiority threatened by the presence of another race, we dislike that race and selze upon every possible objection to It a rationalization of our disike.

"The Orientals consider themselves the equals of, if not superior to, the whites. Before China had been opened up to Western contact, one of the emperors wrote to a Western ruler advising him and his poople that true wisdom was to be found only in the Middle Kingdom." 7

Dr. Sun Yat Sen, the founder of the Chinese Republic, expresses the present attitude:

"Our Chinese civilization has slready advanced two thousand years beyond yours (the whites). We are wiling to wait for you to progress and catch up with us; we cannot recede and let you pull us down. Two thousand years ago we discarded Imperialism and advocated a pollcy of peace. . We have got rid of the old savage, pugnacious sentiments and have attained to a true ldeal of peace." 8

B. Some Specif1c Factors That Gause Race Prejudice Against Chinese

1. Fublic School System (Institutional Influence) In many public schools of the United States, courses such as ethics and civics, which are intended to oreate friendliness between races, sometimes do exactly the

7. Young, K., The Social Paychology of Orlental-occidental Prejud1ces, 1929, pp. 7-9

8. Sun Yat-Sen, San Ming Chu I, 1927, pp. 94-96 
opposite. Text and picture alike endeavor to imbue the pupil with the sense of the superiority of native-born white Americans over any and all other racial groups. For Instance, a Chinese boy returned to his Irlend's home in Hartford, Connecticut, one day with bright red spots burning through his olive cheeks. In the civics course, a brief paragraph was given to other nations to show their good qualities. The glowing tribute to China was, "The Chinese eat rats." The answer of the state Commissioner of Education to a letter calling his attention to this was that "the author of the textbook was out of town. 2. The Yoving Plcture (Recreational Influence) Here is testimony to the effect of moving plctures on chlldren. A corresponent gives a concrete example of international prefudice induced by a film. The film is called "Forelgn Dev1ls" and the story is based on the Boxer Uprising in China in 1900. It was shown Saturday night. Next morning, a teacher in a sunday school class was explaining to his pupils that children of all countries are children of a loving Father. One child replied: "I saw a movie last night; the Chinese are terrible people." The witer was visiting a small town in North Carolina one summer. On his way to the bus station, a young boy, about twelve jears of age, who was riding on a bicjole, stopped in Iront of him and asked this question, "who are you?" In

9. MJers, A.J., "Literature for All ChIldren and Its InPluence," Religlous Education, Apr11, 1936, p. 219

10. Christian world Educetion News Service, Dec., 1927, p. 6 
roply, the witer told him very clearly that he was a Bapt1st missionary student, and was there supplying for the pulpit at the First Baptist Church whose preacher was out of town. The young boy shook his head decldedly and sald, "No, you are not a preacher! I have seen you in the pioture show. You must be Charlle Chan!"

\section{Reading Materials (L1terary Influence)}

Many magazines and story books have plctured the Chinese as criminals. In a recent issue of a detective story magazine, the chief character, being a Chinese, killed his partners in crime to save himself. This charace ter followed no ethical code except that based on ancestor worship. There are many such stories which misrepresent the Chinese people; especially bad are the serials publishod In the comic strips. These give American children a wrong attitude toward the whole Chinese race. In a recent study of the feelings of American children toward the Chinese people, the following quotations are the replies of boys to questionnalre which asked them to write down the names of any people that they did not like and to state why they did not like them.

$$
\begin{aligned}
& \text { "I do not like the Chinese because they are so } \\
& \text { shy, and I am afrald they will plunge " } \\
& \text { knife Into me when my back is turned." } \\
& \text { "The Chinese and Japanese are a stealing and } \\
& \text { distrustful people." } \\
& \text { "Chinese I don't know but I don't like them; } \\
& \text { that's all." } \\
& \text { "I don't like Chinese because of their bring- } \\
& \text { Ing into our country opium." }
\end{aligned}
$$

11. Bogardus, E.S., Introduction to Soc1al Research, 1936, p. 120 
"The Chinese are too crafty."

"I do not like the Chinese because the looks of their slant eyes give me a chill."

"I do not like the Chinese because they have a certain air about them - a sneaking, sliny air."

"Chinese are so backward and refuse to be helped."

C. Messurements of Attitudes Toward Chinese In order to obtain a more accurate idea of social distance between the different racial groups, including the Chinese and Americans, Bogardus has measured this by the 12

following research method:

One hundred and ten people on the Pacific coast were asked to rate the Chinese, Japanese, Hindus, Mexicans, Armenians, and thirty-five other races according to the primary reactions that they experienced toward each race. For example, would they w1llingly inter-marry with the Chinese; would they like to have chinese as chums in their fraternal groups; would they like to have Chinese live as their neighbors on their street; would they like to have Chinese in their occupation (as posible competitors); in this country as citizens; in this country simply as visitors; or would they exclude chinese from the country altogether? The arrangement of cholces is one of decreasing intimacy and understanding - from intermarriage to total exclusion - as determined by fifty judges. The result of his survey reveals that the general opinion in America recognizes that Chinese

12. Bogardus, E.S., "Social Distance, a Measuring St1ck," Graphic Survey, Vol. IVI., 1926, ; 169ff; See also "Social Distance and its Origins," and "Measuring Social Distance," Journal of Appiled Soc10logy, Vol. $\mathrm{LX}, 1925$, pp. 216-र26 and $299-308$ 
should be allowed to enter the United States only as visitors while the Japanese should be excluded from America altogether. The data reveal also that there is a prevalent and decidediy cordial and friendly attitude toward the Canadians and English.

The arithmetical means of the ratings of 110 Amerlcans is given in the following table:

\section{Table XVI}

SOCIAL DISTANCE BETWEEN AMERICANS AND OTHER RACIAL GROUPS (After Bogardus)

\begin{tabular}{lc} 
Race: & Social Distance In \\
\hline English & 0.27 \\
Canadians & 0.30 \\
French & 1.04 \\
Danes & 1.48 \\
Germans & 1.89 \\
Czech-Slovaks & 3.46 \\
Armenians & 3.51 \\
Bulgarlans & 3.97 \\
Negroes & 4.10 \\
Chinese & 4.28 \\
Japanese & 4.30 \\
Turks & 4.80 \\
\hline
\end{tabular}

The Chinese have a social distance index of 4.28 , the Japanese of 4.30, whereas the English have an Index of only 0.27 . Bogardus adds also that these 110 Americans have undergone changes in their opinions of and attitudes toward immigrants in a period of five years. The following table gives a record of these changes with reference to sample races. Bogardus thinks the changes are due to personal experlences elther pleasant or unpleasant. 
Table XVII

CHANGES IN OPINION AND DISTANCE (110 PERSONS) IN FIVE YEARS (After Bogardus)

\begin{tabular}{lccc} 
Maces & More & Less & No \\
Favorable & Favorable & Change \\
\hline Armenians & 23 & 9 & 79 \\
Chinese & 19 & $\frac{10}{34}$ & $\frac{81}{70}$ \\
Germans & 6 & 11 & 96 \\
Hindus & 3 & 19 & 68 \\
Japanese & 23 & 22 & 73 \\
Mexicans & 15 & 0 & 110 \\
Scotch & 0 & 16 & 93 \\
Turks & 1 & 13
\end{tabular}

Thurstone, using the method of paired comparisons, obtained from 239 under-graduates at the University of Chicago their preferences among twenty-one nationalit1es. The preferences are given in Table XVIII in terms of a scale where preference for Americans is adopted as a point of origin.

Table XVIII

NATIONALITY PREFERENCES

(After Thurstone)

\begin{tabular}{lc} 
Race & Scale Value \\
\hline American & 0.0 \\
Englishman & 1.3 \\
Scotchman & 2.1 \\
Irishman & 2.2 \\
Frenchman & 2.5 \\
German & 2.6 \\
Swede & 2.9 \\
South American & 3.6 \\
Italian & 3.7 \\
Spaniard & 3.8 \\
Jew & 3.9 \\
Russian & 4.1 \\
Pole & 4.4 \\
Greek & 4.6 \\
Armenian & 4.7 \\
Japanese & 4.9 \\
Mexican & 5.1 \\
Chinese & 5.3 \\
Hindu & 5.4 \\
Turk & 5.8 \\
Hegro & 5.9 \\
\hline
\end{tabular}

13. Thurstone, I.I., "An Experimental Study of National1ty Preferences," Journal of General Psychology, Vol. I, $1928, \mathrm{p} .405 \mathrm{ff}$ 


\section{4}

Katz and Allport have measured social distance or att1tude toward nationalities in a different way. They asked members of fraternities and societies to indicate their preferences as follows:

"Provided they are otherwise good fraternity material, I feel personally that following types of students should be admitted to my fraternity. Check at the left of each of the following groups (see Table XIX) whom rou think should be admitted."

Students not members of these organizations were asked

a somewhat similar question.

"Assume that you are living in a student rooming and boarding house and are brought into dally soc1el contact with the other students living in the house. The polley as to who should be admitted is to be determined by the roomers already present. Check at the left of each of the following groups whom you would be willing to vote to admit, provided that otherwise they would be desirable tenants in every way. It is to be understood that you would be willing to become a roommate of members of any of the group which you check."

The results of their study are tabulated as follows:

14. Katz and Allport, op. c1t., 1931, p. 145 
Table XIX PERCENTAGE OF STUDENTS WILIING TO ADMIT CERTAIN GROUPS TO
FRATERNIT IES AND ROOMING-HOUSES *

\begin{tabular}{|c|c|c|c|}
\hline Eco & $\begin{array}{l}\text { Home } \\
\text { onomics }\end{array}$ & $\begin{array}{l}\text { Graduate } \\
\text { School }\end{array}$ & $\begin{array}{c}\text { Entire } \\
\text { University }\end{array}$ \\
\hline $\begin{array}{l}\text { Protestants } \\
\text { Working-class students } \\
\text { Nordics } \\
\text { Catholics } \\
\text { Centiles } \\
\text { Conservatives } \\
\text { Students of low social standing } \\
\text { Shabbily dressed students } \\
\text { Grinds }\end{array}$ & $\begin{array}{l}88.6 \\
56.4 \\
40.6 \\
36.1 \\
31.7 \\
17.8 \\
13.8 \\
19.3 \\
18.8\end{array}$ & $\begin{array}{l}90.7 \\
81.5 \\
79.6 \\
79.6 \\
72.2 \\
63.0 \\
40.7 \\
29.6 \\
29.6\end{array}$ & $\begin{array}{l}86.7 \\
68.1 \\
56.2 \\
53.4 \\
43.9 \\
38.0 \\
28.8 \\
26.9 \\
26.7\end{array}$ \\
\hline $\begin{array}{l}\text { Students having relatives with } \\
\text { jail records } \\
\text { Socialists } \\
\text { Jews } \\
\text { Queer-looking students } \\
\text { Atheists } \\
\text { Italians } \\
\text { Reactionaries } \\
\text { American Indians } \\
\text { Agnostics } \\
\text { Slavs } \\
\text { Armenians } \\
\text { Greeks } \\
\text { Students of unconventional morals } \\
\text { Orientals } \\
\text { Turks } \\
\text { Hindus } \\
\text { Students low in intelligence } \\
\text { Bolshevists } \\
\text { Loafers } \\
\text { Anarchists } \\
\text { Negroes }\end{array}$ & $\begin{array}{r}8.4 \\
6.9 \\
10.3 \\
13.4 \\
7.4 \\
5.0 \\
3.0 \\
4.0 \\
3.5 \\
1.0 \\
8.9 \\
3.5 \\
0.5 \\
5.0 \\
0.5 \\
1.0 \\
4.0 \\
0.5 \\
2.0 \\
0.5 \\
1.0 \\
\end{array}$ & $\begin{array}{l}37.0 \\
53.7 \\
40.7 \\
38.8 \\
40.7 \\
31.5 \\
40.7 \\
31.5 \\
37.0 \\
42.6 \\
42.6 \\
40.7 \\
16.7 \\
37.0 \\
33.3 \\
33.3 \\
5.5 \\
22.2 \\
11.1 \\
14.8 \\
14.8 \\
\end{array}$ & $\begin{array}{r}22.6 \\
22.4 \\
20.7 \\
19.5 \\
18.6 \\
17.5 \\
17.5 \\
16.7 \\
14.2 \\
12.7 \\
12.1 \\
10.6 \\
8.6 \\
8.9 \\
8.2 \\
8.0 \\
7.5 \\
7.5 \\
7.0 \\
6.5 \\
5.4\end{array}$ \\
\hline $\begin{array}{l}\text { Average } \\
\text { Total number of students }\end{array}$ & $\begin{array}{r}23.4 \\
208\end{array}$ & $\begin{array}{r}41.8 \\
56\end{array}$ & $\begin{array}{r}23.4 \\
3,515\end{array}$ \\
\hline
\end{tabular}

* Based on the Survey made by Katz and Allport, published in Strong's, The Second-Generation Japanese Problem, 1934 , p. 104

* Since about 12 percent of the students were Jews, the 21 percent including Jews does not indicate a very widespread tolerence in social contacts extended toward members of this race. 
Table XIX shows that the College of Home Economics was the least tolerant and the graduate school the most tolerant. Orientals are preferred to Turks, Hindus, students of low Intelligence, Bolshevists, loafers, anarchists, and Negroes, but they are less preferred than Greeks, Armenlans, Slavs, agnostics, American Indians, etc.

It is refreshing to note that the superior students who have gone on to take graduate work are much more liberal in their attltude toward all the racial groups than the undergraduates. But even they rate orientals below all racial groups except Turks, Hindus, American Indlans, and Negroes. They, however, consider inferior to the orlentals the followlng: shabbily dressed people, grinds, Bolshevists, stum dents with unconventional morals, anarchists, loafers, and students of low Intelligence.

$$
15
$$

Goodwin B. Watson has reported on the attitudes of over 3,000 persons regarding five Pacific Ocean problems. The questionnaire called for replies on fifty-seven 1tems as to "how do you feel" and eighty-one 1tems as to "what do you think". The instructions and several samples follow:

\section{A. HOW YOU FEEL}

"D1rections: Read each word listed in capital letters in the following column and think quickly how you feel about it. Notice your own Immediate reaction to $1 \mathrm{t}$ before you read further. Then read the words or phreses suggested about it, noticing which comes nearest to agreeing with your own reaction. Write the number of that word or phrase in the parentheses in the right-hand margin. If none seoms just right, choose the one which comes nearest to expressing your feeling.

15. Watson, G.B., Orlent and Accident, American Group of the Institute of Pacific Relations, 1927, p. 42 
If several appeal to you, choose the one truest to your first quick response. Do not try to reason out the $\log 1 \mathrm{cal}$ best one

1. JAPANESE: (1) Alert and progressive;

(2) Unt rustworthy; (3) Courteous; (4) Ingenious;

(5) Concelted; (6) Polltically ambitious.

2. CHINESE: (1) Laundry; (2) Cruel; (3) strange; (4) Highly cultured; (5) Beauty-loving; (6) Dependable.

3. SOVIET RUSSIA: (1) Spreading confusion In China; (2) Plots; (3) Won't work; (4) Helping China; (5) Bold Idealistic experiment; (6) Good and bad, fifty and fifty.

4. YELLOW PERIL: (1) Jingo press; (2) Real danger; (3) Caused by white imperialism; (4) Over-stressed; (5) Eventual; (6) No longer used even in propaganda."

B. WHAT YOU THINK

"Directions: Please indicate your opinion about each of the statements below by drawing a circle around the letter or letters in the margin which express your judgment. Th1s is what the letters mean:

$$
\begin{aligned}
& \text { T - True (absolutely) } \\
& \text { PT - Probably or Partiy True } \\
& \text { D - Divided, in Doubt, Open Question } \\
& \text { PF - Probably or Partiy False } \\
& \text { F - False (absolutely) }
\end{aligned}
$$

If you do not know enough about an 1tem to express any opinion about $1 t$, cross it out.

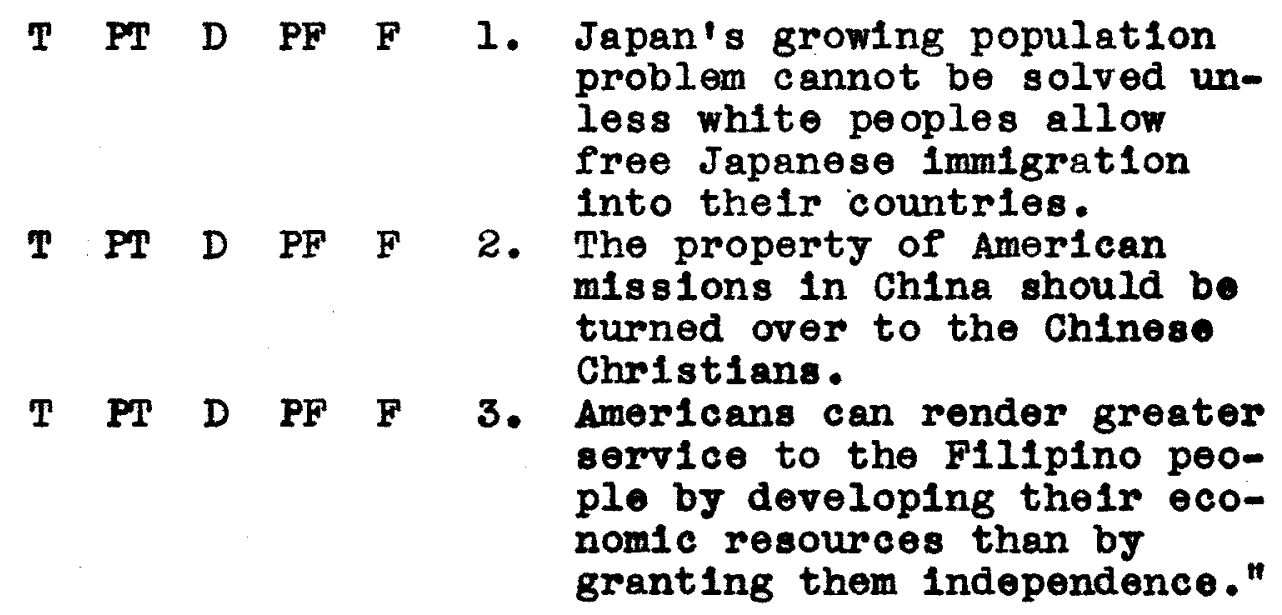


In addition, the subjects were asked questions regardIng their geographical location, the extent of their travel, and their nationality, education, religion, membership in socleties, reading, etc.

Watson stresses quite properly that the replies furnished in this investigation are not necessarily indicative of the attitudes of the people in the United States and that furthermore, since only about one-third of those to whom questionnalres were malled replied, the results may not properly represent the groups mentioned, as answers are more apt to come from those interested than from those not interested.

In order to summarize the large number of 1tems, Watson combined many of them under five headings: namely, attitude toward Chinese, toward Chinese National1sm, toward Japanese problems, toward Philippine Independence, and toward United states policies. The material included under these headings is grouped according to its favorable or unfavorable character, as two pertinent sections indicate:

\section{ATTITUDE TOWARD CHINESE}

"Favorable: The extent to which the group recorded any agreement with such ideas as - That the Chinese are dependable, cultured and equal to Americans in intelligence; that there can be mutual understanding between the races; that we have a great deal to learn from the chinese; that the Chinese imnigrants should be treated as are other 1migrants; that Chinese history should have a place in our schools.

"Unferorable: The extent to which the group recorded any agreement with such ldees as That the Chinese are of inferior intelligence, unclean, cruel, and that we have little to 
learn from them; that there can be no mutual understanding between Chinese and Americans; that the Chinese should not have the privileges accorded to European immigrants."

A few of Watson's summaries are included in Table XX. The American students residing at the International House, Columbia University, are very "favorably" disposed toward these five problems, whereas the relatively few farmers included in the study are distinctly "unfavorable." In between are the other groups, with laboring men tending toward "unfavorable" attitudes and women and students tending in the opposite direction. Business men are about equally divided on the first three problems and "unfavorably disposed on the last two, that is they are opposed to Philippine independence and they support an imperialistic policy for the United States.

It is difficult to compare these results with those obtalned by Bogardus, Thurstone, and Katz and Allport; but It would appear that Chinese are rated higher here than in those other studies. It 1s, however, the votes of the students and teachers that are responsible for the favorable average attitude toward the Chinese. Business men are slightly favorable, and laboring men unfavorable. The groups are about equally favorable toward Chinese and Japanese problems, being slightly more favorable toward the Chinese than the Japanese. 
Table XX

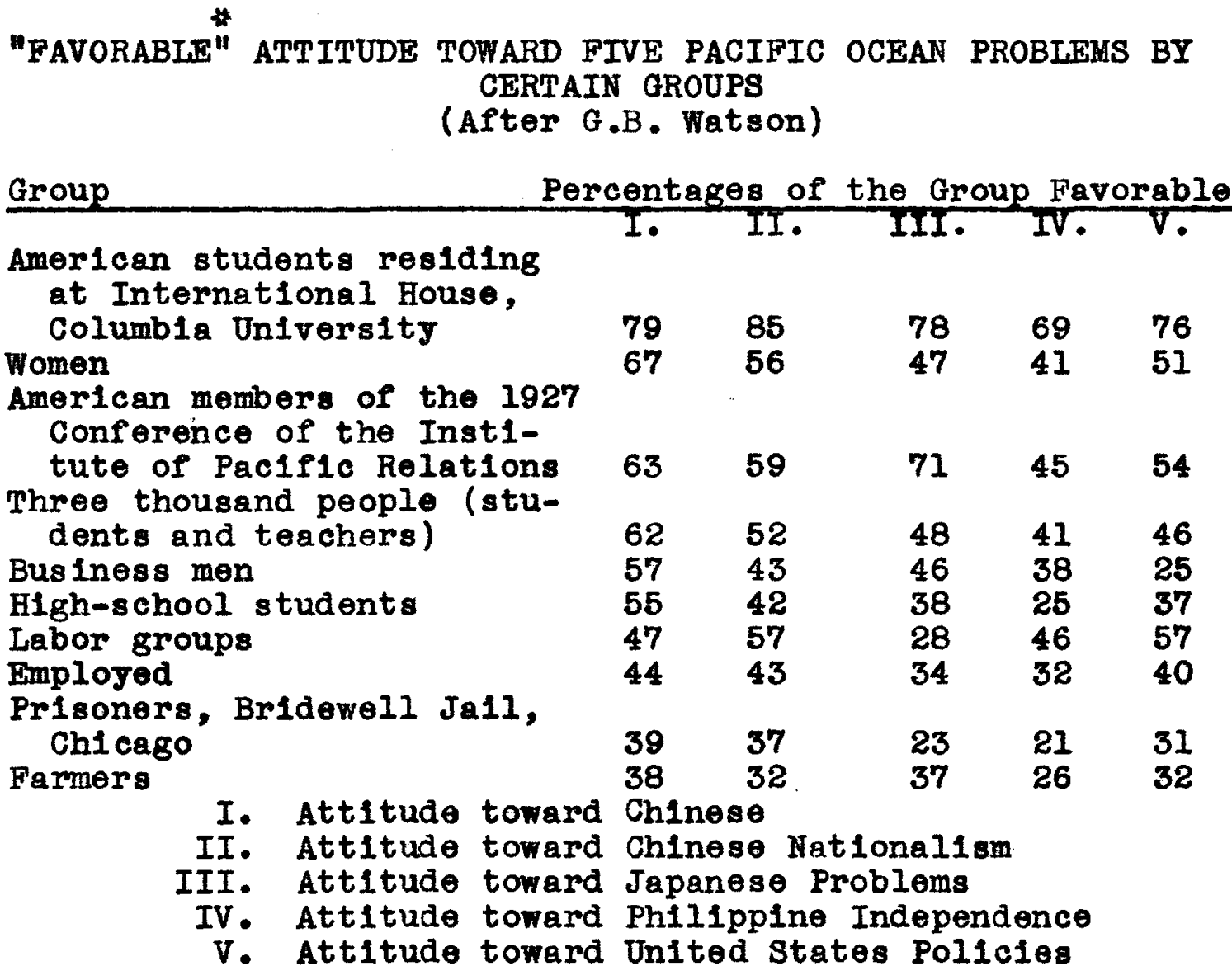

* The term "favorable" has reference to the items of which two groups are given in the text in contrast to the "unfavorable" 1tems.

"The labor groups showed an unusual number of objections to the Chinese, a high degree of interest in Chinese nationalism, the largest amount of opposition to the Japanese, the strongest expression of the desire to make the Philippine Islands independent, the greatest opposition to forelgn missions, the least antagonism to the Soviet, and a somewhat lower information score on the fact items involved. The women's clubs and housewives showed a smell amount of objection and a large amount of favor for the Chinese, little objection to Chinese nationalism. The group of farmers was too small to permlt valid generalization. This particular group seemed to be very cautious, seldom expressing opinions for or against the 1ssues involved. Partly because of this general tendency they showed the least favor for China, the least interest in Chinese nationalism, the smallest degree of opposition to, or interest in, 
forelgn missions. In spite of this generally low per cent of response, they were distinctiy on the side of the imperialists so far as the policies of the United States are concerned." 16

"The tendency is fairly clear for those with oriental friends to be more favorable to the Chinese, more interested in Chinese nationalism, more favorable to Philippine independence, more opposed to imperialism, less interested in missions, and better informed on the orient." 17

The effect of travel abroad upon attitude toward these problems is rather uncertain, possibly because most of the travelers had visited Europe and not the Orient. The effect of reading is also not clear because of the varlety of reading that is indulged in. On the whole, it appears that "the best informed were most likely to have a favorable attitude toward the Chinese and Chinese nation18 al1sm.

D. How Race Prejudice May Be Lessened

As has been pointed out above, race prejudice is an outgrowth of the peculiarities of human belngs, so that for practical purposes it may be viewed as a type of behavlor that w1ll arise when two different groups are brought together under ordinary conditions.

We have shown that this type of behavior arises for the following reasons: (1) The first reaction to an observation of difference is a feeling of strain and uncertainty; (2) the readjustment to a new s1tuation involved in contactIng a race different in looks and customs is unpleasant to those with established habits; (3) because our own status

16. Watson, G.B., op. cit., p. 42

17. Ibid, p. 46

18. Ib1d, p. 48 
1s affected economically or our feeling of superiority threatened by the presence of another race, we dislike that race and seize upon every possible objection to it as rationalization of our dislike; (4) our flrst unfavorable reaction to the member of another group tends to become the stereotyped reaction to all members of that group.

"Eliminate the cause and cure the disease" is a sound precept in medicine. It may well be applied to the state of mind we are considering.

Already the fact that Chinese imigration has ceased and that consequently the fear of economic rivalry has been removed from America, especlally California, has eliminated much of the hard feeling in this country toward the oriental. Agitation is practicaliy a thing of the past. The Chinese can now be judged on their merits, not as a growing menace. The second-generation Chinese may remain oriental in face and figure. But in address, speech, and manner they are more and more like the American type. The degree of difference between Orientals and Americans will become less with each generation, although differences w1ll always be present. Similarity in ethical standards and 1deals is the great common denominator.

The stereotyped reaction can be broken down only by greater experlence. Because stereotypes are often gross exaggerations of the real situation, there may be a strong reaction against them when the facts are known. Usually they are so engrained in one's emotional life that a single 
favorable impression 18 not sufficient to offset the earlier unfarorable attitude; but the latter may be outwelghed by ten favorable impressions.

Sir Henry Thornton tells us that "the first factor in improved international relations to which all others are subordinate, must be an understanding of each people with respect to other peoples." This is to be accomplished by education through "study, travel, and instruction from those who are competent to teach." "A nation," he says, "1s more than flelds, workshops and mines; its reaction will be determined by the spirit and mentality of 1ts citizens. And if we are to understand the peoples of other nations, we must understand the spirit that moves within them, that $11 \mathrm{v}$ Ing spark, intangible and ethereal, which is the self-starter of all national activities. There is an old proverb, 'know thyself,' and far more important it is to know thy neighbor." The conclusions of Watson, given above, together with 20 those of Reynolds and others, raise doubts as to the effectiveness of study, reading, and travel in eliminating race prejudice. Apparently these have an amellorating effect, but it is clear that college graduates may be as strongly possessed of a given stereotype as anjone else. There is a challenge here to our educational institutions that instruction shall not only involve facts but that it shall be

19. Thornton, H.W., Men and Industry, A Brackett Lecture at Princeton University, 1931, p. 12

20. Reynolds, C.N., "Oriental-White Race Relations in Santa Clara County, California," unpublished Ph.D. Thesis, Stanford University, 1927 
applied to practical problems involving prejudice. Race prejudice will not be minimized until the educational forces of the world are directed to this end. The study of history introduces us to other peoples, but the gain from added acquaintanceship may be more than offset by the inculcation and fostering of unfortunate stereotypes. "Did not the English stir up the Indians to massacre our forefathers?" questioned an American. How much of the suspicion of England in the minds of Americans today is due to the implanting of such emotional bits of dynamite in them when in school as chlldren.

The present forms of education are helpful in combatting race prejudice; they could be made far more so. But seemingly the best way to combat prejudices which are so easily inculcated with respect to an unknown group is to increase acquaintanceshlp with representat1ve members of that group.

\section{OCCUPATIONAL OPPORTUNITIES}

The second vital problem which Chinese immigrants are facing today is an economic one. Even before the depression made the finding of a job hard for anjbody, it was permanently hard for an oriental. He knew in advance, or else soon learned, how many doors were closed to him. The jobs open to him are, first of all, those strictly within the Chinese communities. He may be a professional or business man serving his own people, or he may open a store selling orlental goods and curlos to white people. Then there are 
certain marginal positions where Chinese may work for an American concern in connection with its oriental trade, especially where a knowledge of the Chinese language is essential.

A. Reasons for Scarcity of occupational Opportunit1os The reasons why the Chinese - especially Americanborn Chinese - experience greater difficulty in getting employment than any other American citizen of foreign descent, are as follows:

(1) Although many Chinese immigrants, especially the second-generation Chinese, are American citizens, still In appearance they are foreigners, and give that impression when they call upon anyone, whereas people of European de21 scent may pass in appearance for Americans. As one Chinese has said:

"There may be no color line drawn against oriental students attending school, but there is a line drawn against employing our students after they have graduated from the institutions of higher learning. Business firms on the Pacific Coast offer us no opportunity of practicing what we learn at the school. . Recently two friends of mine went to a trans-Pacific steamship ilne to apply for jobs as common laborers on the boat. The superintendent at first told them that it was not the policy of the firm to hire people other than Americans. The bojs told him they were American-born and did not come into the excluded 11st. They talked with the superintendent a while and finally he said, "I am sorry, boys, but I cannot employ you people." If the American people were our friends they would surely give us an opportunity to learn our profession outside of the University laboratories." 22

21. Takamine, Eben J., Employment of Second-Generation Japanese in New York City, 1928

22. Smith, W. $\cdot$. The Second-Generation Oriental in Amer1ca, Inst 1tute of Pacific Relations, HonoluIu, 192\%, p. 51 
(2) Employers are often unwilling to employ a Chinese Immigrant, because they belleve he is a forelgner and will shortly leave them to return to China. It is only natural for employers to prefer taking on men whom they can count on to stay with the company as long as their work and progress are satisfactory.

(3) The opposition of fellow-omployees, particularly when Chinese or Japanese are promoted over them.

(4) Fear on the part of employers that some of their customers may object to dealing with Chinese or any other forelgn group, and that business will be lost therefrom.

(5) Second-generation Chinese are not able to get employment from the Chinese-American firms due to the fact that they do not know Chinese sufficlently well to carry on their work, and also that there are not enough of these firms to take care of so many second-generation Chinese children. The reasons why second-generation Chinese do not learn Chinese well are many: In the first place, Chinese is a very hard language to learn, especially to write. In the second place, Chlnese language school work is given mostly after the American day-school work is done, in the late afternoon or on Saturday. There are only a few schools in the country and these are not conducted on a compulsory basis (See Chapter III, section dealing with "education"). Th1rd, young Chinese do not see the need of learning Chinese unt1l they are elghteen or nineteen years old, and by then 
1t is rather late. Fourth, there are not enough Chinese language schools; in the Southeastern States, there are only two, one at San Anton10, Texas, and one in the Mississippi Delta near Greenville, which is still in the process of getting organized. And since most of them are "pay schools," not all Chinese can afford to attend them.

(6) The Amer1can-born Chlnese are too thoroughly Amerlcanlzed and are not capable of securing work in China and fitting into Chinese society. They have been born in American communities, and they have attended American schools, they speak English exclusively, they know pract1cally nothing of China except what average Americans know; their ideals, customs, mode of thinking, their whole psychology is American. Although physically they are Chinese, culturally they are Americans. They are not able to speak the Chinese language or read Chinese papers. They are totally ignorant of Chinese customs, history, and traditions.

(7) Most of the Chinese came here without capital. They have acquired something, but not very much. It is true that a few have made fortunes and others will do likewise. So, on the whole, the Chinese immigrants are greatly handicapped by lack of capital for the development of large bus1ness operations. However, as they gradually cease to send money back to relatives in China they will accumulate capital more rapidly. But their present financial status prevents them from starting new business operations.

(8) The discrimination is even harder on women 
than on men since vocations like terching and nursing are closed to them in many states. Perhaps the only occupation which the Chinese immigrant girls can enter is marriago since there is a strong emphasis upon marriage and family Iife among the orientals. Every Chinese expects his girls to marry. But even in this respect, many second-generation women are faced with a serious situation in that there are not enough eligible men for them to marry. Men of their own generation are of the same age or younger and have not established themselves to the point of being able to support a wife. Men of the first-generation are usually much older, have been brought up in China, and hold 1deas $8 \mathrm{~s}$ to the proper role of a wife entirely different from those held by second-generation women.

Indeed, the occupational opportunities for the chinese Immigrants, both forelgn and American-born, are very scarce and the situation is a very serious one. The following is an excerpt from a letter of the San Francisco editor, Ny Poon Chew, to Samuel H. Cohn, dated July 4, 1929.

"The problem as to the livelihood of the comm ing generations of the chinese born in this country is a serious one. There is considerable race prejudice existing today against the Chinese in the higher lines of the economic field. I know several Chinese young men, graduates from our state University in engineering simply could not procure a position because white skinned races would not work under or with them. One of them was employed by a large public utility corporation for a while and his work was found to be satisfactory, but eventually he was discharged in order to keep peace and harmony in the camps among the men...

"These young people, like thelr Amerlcan cousins, simply would not return to the farms or to agricultural work. They all want to stay in the cities and procure white collar jobs. And under no 
circumstances would they go to work as house servants or laundry work. There is now only one way open to them to procure a livelihood and that is in the commercial lines and even in these lines they have to confine themselves to their own people. Since the enactment of the chinese exclusion laws in 1882, the number of the Chinese people in America is steadily decreasing until today we have less than sixty thousand in the whole United States, and 1t looks as though in ten or twenty years the Chinese population in this country would be so few that commercial activities will be so reduced that they 111 not be of any consequence."

B. Some Possible Solutions

Some of the possible solutions which may be

offered are:

1. It has been suggested in certain quarters that the solution to the chinese problem may lie in a widespread diffusion of the Chinese population over the United States, especially in the East, where social prejudices are supposediy much less intense. This process has already been carm ried out during the recent Jears due to economic pressure on the Western Coast; but it has not solved the problem. Jobs have not always been available in the new locations.

2. Another alternative is for the second-generation Chinese to work exclusively for those of Chinese ancestry. This is a possibility for some; and we find Chinese physicians, dentists, insurance men, and the like who devote most of their time to serving their fellows. But again, as has been pointed out in Mr. Ny's letter, the number of Chinese immigrants in America has been steadily decreasing since 1882, and the time will soon come when they w11l be too few in number to create self-contained communities. 
The businesses they have so far built up are very small, averaging one-half employee each, so that there is very little opportunity for the second-generation to get ahead in this way, except by replacing their elders.

3. First-generation Chinese have demonstrated that they are successful in the restaurant and laundry businesses. Why, then, do not members of the second-generation continue the work of their "elders"? There is no doubt that this is the fond hope of many a first-generation Chinese who has tolled long and hard in this business and would like to see his sons selze the advantages denled him. The writer knows severel oldmfashioned, conservative Chinese who have even refused to send their children to 3 chool in order to force them to take up the work at which they have labored for years. The trouble with this solution is, of course, that the second-generation Chinese are like other young people educated in American schools - they want white-collar Jobs.

But the writer believes there is a great possibility in the restaurant and laundry businesses. So far the Chinese have built up a fine reputation in these fields. They have given to the Americans novel eating-places in which chop suey and other dishes are served. These are not truly Chinese but are adaptations of Chinese foods to American taste. There are st1ll few Chinese restaurants, especially in cities in the southern states. It is the general opinion among the Chinese that the people in the South are proud of 
their own cooking and thus do not like Chinese food. But if the chinese will specialize in food that is novel and at the same time appetizing, and adapt their dishes to the Southern taste and serve them in a unlque setting, they can open many new and profitable restaurants in the south. The chinese hand-laundry can also be Improved by using modern methods to increase its efficlency and service.

4. Agriculture offers another opportunity for employment, the establishment of a home, and the chance to prosper. Here the Chinese are wanted, for they are among the best workers and come into least competition with the Occidental elements of the population. Since there is no legal restriction against the second-generation Chinese leasing and buying land, they can establish homes on farms and raise Chinese vegetables. There are real opportunities for expanding this occupation; horlzontally, by increasing the production of vegetables, berries, and other oriental agricultural products; vertically, by controlling the marketIng of these products from producer to consumer 10cally. The Chinese have already established successful vegetable markets and grocery stores in the Southern and Southwestern States.

5. Perhaps the best solution will be for Americanborn Chinese to look to China for their life work. In this there is much hope. China, with her present united government, w11l open thousands of lines of work in which ambitious, modernized young men and women can utilize their learning to help develop the country's resources. There are, 
however, many cases where the joung ChInese who go back to China are unhappy. The reason is probably due to the fact that the Chinese born in China, but educated abroad, come from the best families and have influence on their side; whereas the Amer1can-born Chinese came generally of a peasant ancestry and have no such backing. There is, therefore, a possibility of their being disappointed in their hopes when they go to China.

\section{The Need of Vocational Guidance}

The Chinese immigrant youths do not know how they are to earn a living. But this is typical of young people everywhere. Too many belleve that if they secure an education, a good job will be supplied them. Many have only a hazy notion of what they want to do; evidently they have given little thought to the whole problem.

Vocational guidance is especially needed by the secondgeneration Chinese for the reason that they come into contact with fewer occupational activities and that their parents and friends cannot help them very much. American schools supply some information, but they notoriously direct students away from trade and agriculture into "white-collar" jobs and they give pitifuliy little information about economic ilfe. It is unfortunate that what pertains to earning a living is viewed as vocational, not cultural, and that it is so often felt that only cultural subjects should have a place in high school or college. It is therefore not surprising that there is a large minority graduating from col- 
lege with no 1dea of what they are going to do to earn a 11ving.

To meet the problem American civic and social agencies should help the Chinese to organize vocational bureaus in all the large Chinese centers, each of which should be under the direction of a competent, technically trained, lofty visioned, and well-informed assistant director, with a director over all the bureaus. Each of these bureaus should be correlated with an employment bureau.

Before launching such an enterprise, an extensive research into the extent and distribution of various vocational fields would be necessary. Experts in vocational guidance should be employed to survey the field and to study the occupational possibilities of the second-generation Chinese. They should travel about the states and collect data regarding the occupational plans of the Chinese youths and the occupations they are actually entering and their success therein. After the survey has been made, they should supply the information not only to the Chinese themselves, but also to all the counselors in the school system, who in this way would be better prepared to handle the Chinese with whom they come into contact. It is fatal to the best interests of the second-generation Chinese for the school authorities to believe that the Chinese vocationsl guidance problem is so distinct that their own representatives must handle it. The program of work of these vocational bureaus should involve the following steps: (1) First, the analysis of the 
Individual regarding his psychological characterlstics, his physical condition (medical and psychiatric examination) and h1s industrial experlences. (2) Second, the occupations for which he is seemingly best fitted should be called to his attention and information concerning them put at his disposal. (3) Third, when he has made his decision, a proper training program should be mapped out. Higher education and shorter technical training should be encouraged and scholarship and loon funds should be established for needy students. (4) Finally, the bureau should help to place the individuals in occupations and aid them in getting started in positions. Most of the employment agencies have achieved with varying degrees of efficlency the fourth task, but very little has been done on the first three.

The Government of the United States has done very well In making provisions for the educational facilities of Chinese 1migrant chlldren. The time has come for 1t to establist and maintain agencles whereby these immigrant children may be gulded into the type of education for which they are best fitted and to ald them in getting started in a job. The government can best discharge this important task by cooperating with Chinese parents in analyzing the vocational interests of their chlldren, prescribing new courses of trainIng, and placing them in new positions unt1l the individual has found a place where he can earn a living. All this is actually much cheaper than the maintenance of present rellef agencies, and of courts, reform schools and penitentiaries. 
III. SOME VITAL SOCIAL PROBLFMS

There are many social problems existing among the Ch1nese immigrants. The following are a few of the outstanding ones:

A. Conflict of Standards Between old and Young Generat1ons

Chinese immigrants range in type from the traditional to the up-to-date American. The traditional type comprises the large percentage of the older Chinese who have brought with them a family-clan-village type of community, encased in centuries of organized traditions. Such a community is well knit together and conflicts with American life. The second-generation Chinese often find themselves in especially difficult situations. On one hand, they owe alleglance to a hard and fast system of parental control over them; on the other, they are attracted strongly by the freedom accorded American children. Thus, second-generation Chinese are confronted with such a welter of dilemas, so rull of conflicting 1deas, 1deals, and aspirations, that Iife resolves itself into a series of starts and stops, with the expenditure of much energy and with little or no progress in any direction. Shall they be essentially Chinese or American? Shall they stay here or go to China - or some other place, such as South or Central America? Shall thoy attend college or not? Shall they marry as their parents

23. Bogardus, E.S., op. c1t., 1936, p. 75 
direct or as they themselves please? Shall they be Buddhists, Christians, or non-bellevers? And, above all else, what shall they do to earn a living? Indeed a second-generation Chinese child has meny more causes for bew1lderment than an ordinary white child. The newspaper is full of storles and tragedies regulting from the confliet between the older and younger generation, which constitutes one of the most vital problems in the Chinese immigrant family. Reports of the Chinese youth revolting against their conservative parents are many. The case of Shong Liu Bow 1s an example of such conflict: 24

"An eighteen year old girl ran away from her mother and her mother's chop suey restaurant in Cleveland, Oh10, to the home of her white friend, Dorothy Hooper, and begged Dorothy's father to adopt her. To the judge who heard Mr. Hooper's petition that he be made her guardian, Shong Liu Bow sobbed that her mother wanted her to follow Chinese customs and traditions for which she had no sympathy. She wanted to be American, not Ch1nese. Sternly the judge admonished her not to be ashamed of her Chinese birth, sent her home to her mother."

That this tension with parents may go to a very undesirable length is 1llustrated by the following frank story 25

of another California girl of Chinese ancestry:

"I was born here in Chinatown and attended the city schools and graduated from the high school and have had two years in the State College. When I was a little girl, I grew to dislike the conventionality and rules of Chinese life. The superstitions and customs seemed ridiculous to me. My parents have wanted me to

24. Life, January 25, 1937, p. 59

25. Emith, W.C., 오. c1t., 1927, p. 53 
grow up a good Chinese girl, but I am an AmerIcan and I can't accept all the old Chinese ways and 1deas. A few years ago, when my mother took me to worship at the shrine of my ancestor and offer a plate of food, I decided it was time to stop this foolish custom. So I got up and slammed down the rice in front of the ldol and said, 'So long, old top, I don't belleve in you anyway.' My mother didn't like it a little bit."

A much more serious condition results from the differe ent points of view of the two generations regarding marriage. As one second-generation young woman puts it:

"In our parents' days in China the young people were married without even seeing each other, the marrlage being arranged between the two families by a go-between. Before consent was given by the parents of either party, the hiatory of the other party's family was carefully examined in regard to soclal status, reputation, disease or other defects. The first generation now in the United States have never experienced that romantic 11 fe that American boys and girls as well as our second-generation Chinese have a tendency to enjoy. The firstgeneration somewhat object to the American custom, and we think it perfectly natural. What the young people think good in a young man or young woman of their cholce, the first generation consider unimportant and immediately begin investigating about the past record and family history in which the second-generation have little thought. We like to, and have a tendency to $11 \mathrm{ve}$ today, and look forward to bullding a future, together, whereas the firstgeneration considers the past more important."

The writer knows a girl at Shreveport, Loulsiana, twenty-two years of age and a high 8 chool graduate, who has already "stalled off" four proposals brought to her father by friends of comparatively unknown or personally repulsive men. Her father is fond of her and, unlike many firstgeneration fathers, has not forced her to marry against her wishes, but she says that if her father knew that she is 
holding off in the hope of arranging her own love marrlage he would make her marry the next one that comes along. So saturated is she in the custom of obedience to her father that she seems to feel she would have to obey. The matter is made worse because of the girl's age, twenty-two, which is a terrible age for an unmarried Chinese daughter to be st1ll on her father's hands. People are already beginning to ask what is the matter with her, that she cannot secure a husband. All. reports seem to indicate that the secondgeneration women are marrying to a greater extent and at an earlier age than white women.

\section{B. Segregation in Social Relationships}

The social contacts between the white and Chinese heve been largely restricted to those made by the younger generation in school and in a few churches. In many states, school segregation laws were intended to eliminate even this, but the law has never been put into operation except in the state of Mississippl and in a few small school systems in the Pacific states.

But there are many legal restrictions that have prevented the first-generation or the older Chinese from enterIng into the life of the community. Their ineligibility to citizenship removed all possibility of their taking part in political matters. The Anti-alien Land Law a prevented them from taking root in rural communities. The miscegenation 
law in nine states forbids intermarriage. All these factors tend to keep the two races apart.

On the other hand, the nature of the Chinese familyvillage communtty is so different from that of the American community life that its utter strangeness to, and widespread misunderstanding by, Americans is common. For instance, the "Tong" method of providing justice, and its extreme procedure "played up" in the American press, has made the Amer1cans serlously discount the whole race. The so-called "Telepathic understanding" - or personal means of communication In Chinatown - is so perfected that it has created a lot of mystery on the part of the Americans who think that there are "no secrets in Chinatown." All these factors lead to the Chinese segregating themselves completely from the Amer1can life. By having almost nothing to do with one another socially, with no political contacts, and with only a fow economic lines of contact open, the two races have effected a nominal accommodation.

Thus everything runs along smoothly unt1l a "Tong War" breaks out in Chinatown, and then the press brings some of the spectacular phases of Chinatown life vividly before the American public and new waves of abhorrence pass over the American mind, but they usually produce no action inasmuch as the "Tong Wars" do not ordinarily affect American life

26. Mears, E.G., Resident Orientals on the American Pacif1c Coast: Their Legal and Economic Status, 1928, p. 42 
and property.

The family-v1llage system, however, is gradually breaking down among the younger Chinese. The older rule-ofthumb, Irrational types of control are unsatisfactory to the younger generation who are breaking away from them. The dictum that "father did it" no longer rules. The reaction, however, mey carry the younger Chinese to the extreme and the "sheik, flapper, and smart-set" types become conspicuous. These developments indicate that the Chinese, when released from the hard and fast family-village traditions, are capable of adjustments, assimilation, and Americanization.

\section{Intermarriage}

Intermarriage of Chinese with whites is rare, den spite the unbalanced sex distribution. This is probably due to the fact that the Chinese have a desire to keep their blood pure. The recent strict restriction of immigration has, however, increased the tendency to marry natives of America since they cannot bring the mates of their ow stock from their native land. It is also true that not many wellto-do white women like to marry Chinese. So, while a few Chinese men associate with the lowest elements of the white population, with prostitutes and degenerates, most of them 11ve a life of solitude. They have been isolated as if they were lepers on an island. They are not permitted to bring their wives here; nor are they allowed intermarrlage with whites in accordance with the law in nine states. The United states, therefore, is a place where they come to die, not to 11ve. 


\section{PROBLEMS OF EDUCATION}

\section{A. Segregation of Chinese Pup1ls in Public Schools \\ Due to the pressure of public opinion, many states} have made provisions to keep the children of different races apart. For instance, Chinese children are not allowed to go to school with wh1te children in M1ssissippl and many cities in California. In many places, conflicts have developed between school and home with respect to attitudes toward segregation. The following case is self-explanatory:

"Parents of the striking students of the John Swett School in Oakland were threatened with arrest yesterday by Fred $M$. Hunter, Superintendent of schools - . . all but about 37 of the white students of the school have been removed by their parents as a protest against the continued refusal of the school authorities to deny the 18 Chinese pupils entrance to the regular classes. A Committee of the mothers of the striking students, armed with affidavits that the superintendent had promised the removal of Chinese, have canvassed the district in an attempt to have the parents of the remaining 37 white children withdraw them from the school." 27

Racial segregation raises two sets of questions. The first centers around the reason for segregation, as Bell has 28

pointed out.

What led to segregation? Are there fundamental, val1d, causative factors, based on known mental and educational differences between the children of Chinese and Japanese immigrants on the one hand and those of Caucasian parents

27. Daily Colifornia, September 30, 1936

28. BeII, Reglnald, "A Study of the Educational Effects of Segregation Upon Japanese Children In American Schools," Unpublished Ph.D., Thes1s, Stanford Un1versity, 1933, p. 1 
on the other? Are the social ideals and behavior of the one group so diverse from those of the other that school administrators have found it essential to separate them? or is the vastly important but propaganda-based fact of race prejudice the fundamental underlying cause?

Undoubtedly, one cause of segregation of school ch1ldren by nationality or race is undue concentration in one district. No one particularly objects to the presence of a few foreigners, but when they outnumber your orn child's group the matter is more serious. Th1s is the actual situation in many districts in California and segregation is thus established to meet the demand of the public. For instance, in San Francisco, the first Oriental school to take care of Chinese and Japanese pupils was established In 1885, in accordance with state leglalation of various years beginning with 1866. Since then, many schools of the same nature have been established in many school districts In Sacramento and Placer counties and in the Bouldin district near stockton, California, where a large proportion of orfental families have settled.

The second set of questions centers around the results of segregation. What are the effects upon the educational progress and social and civic attitudes of the children of Chinese parentage of this segregation in American schools? Does either the one group or the other do better work in school because of the absence of the other in their classes and their school associations? Do the chlldren of the 
Asiatic Imigrants progress more rapidly and more satisfactorily when they are regarded as a separate unit in the educational scheme, separately housed and taught? Do the children of Caucasian parentage in these districts where there is such a large proportion of Chinese and Japanese families progress more satisfactorily when the children of the latter are separated from them in their educational and recreational activities? Or are the effects of segregation negligible one way or the other?

So far, no one has made any extensive study of these aspects of the problem. However, the following conclusions 29

made by Bell in his study of the effect of segregation on educational status and progress of children of Japanese parentage are applicable to the Chinese. His conclusions are: (1) The children in segregated schools are better off than those in non-segregated schools, for in nearly every school subject they advanced more rapidly. (2) Children in segregated schools, however, scored lower on the lingulstic items, in proportion to the remaining items, than did the non-segregated children. They are more backward in the use of the English language.

Segregation, however, affects Chinese in California more than the Japanese, since there are today only four schools in which Japanese are segregated. These are small schools and there is no movement to increase their number.

29. Bell, Reginald, Public School Education of SecondGeneration Japanese in CaI1fornia: 1930 
But Chinese are segregated in many schools on the Pacific Coast; therefore it is a practical problem for Chinese but merely an academic problem for the Japanese.

B. Education for Chinese Ch1ldren in M18s1ss1pp1 Delta Mississippl is another of the states in the Union which excludes Chinese chlldren from 1ts public schools. The situation here is different from that in California. In only a very fow communities are they allowed to attend the white schools; in most communities instead of providing segregated oriental schools for the Chinese children, the State Government requires them to go to school with the Negroes. Of course, the Chinese consistently refuse to send their children to Negro schools and so for a number of years Chinese ch1ldren in the Mississippl delta have been without any educational facilities except for such part-time tutoring as their parents may be able to afford.

The maln reason for segregation in Mississippi has been economic. The Chinese control practically all the grocery business in the Mississippi delta and this has not pleased the white business men. Another reason is that some of the Chinese people in Mississippi, who are barred from bringing their own wives to this country, married Negro women. The people in the South who consider the Negroes inferior to themselves thus also look down upon the Chinese.

Many cases have been brought to the attention of the State Leg1slature; but very little success has been made in securing educational provisions for the. Chinese children. 
The following is one of the many cases that had attracted

the attention of the public through the newspapers:

"In 1925, Martha Lum, a nine year old Chinese girl was excluded from the school by the Board of Trustees of the Rosedale Consolidated School, relying on the ground that she was not a member of the white race. The constitution of the State of Mississippl provides for separate schools for 'children of the white and colored races,' and the state supreme court held Martha Ium could not insist on being classed with the whites."

Judge Etheridge of the state Supreme Court in his decision said "If the Plaintiff (Lum Gong Family) desires, she (Martha) may attend the colored public schools of her district." Lum Gong, the father of Martha Ium, brought the case to the Supreme court of the United States which again upheld the decision of the Mississippi state supreme Court.

As a result of such negligence, more than 150 full blooded Chinese children in the Mississippi delta today know a little bit of English and a little of Chinese, but not enough of either language to be able to find their way in the modern world here or in china. A few children have been sent back to China for their education. The following cases were reported by The Commercial Appeal, Memphis, Tennessee:

"It is at the Chinese mission that one hears of Henry Joe of Boyle, Mississipp1, whose flve children previously have been allowed to attend the white school at Boyle, but this year were excluded. . of Wong Tu and his wife of

30. The Cris1s, December, 1926

31. The Commercial Appeal, Memphis, Tennessee, February 14, T931, Section 4, p. I 
Alligator, Mississippi, who have decided at last to send their four chlidren back to China for their education, keeping only the baby here with them."

There are some 1,500 Chinese in the whole Miss1ssippl delta, the largest Chinese colony in the South, all of whom are merchants, mostly in the grocery business. The approximate number of grocery stores operated in this district is 300 with an average of four persons to each store. Most of these immigrants are married but have left their wives and children behind them in China because of the educational advantages which they can secure in Chine but which are denied to them in Mississippl. This explains the fact that there is but one child to every ten chinese inhabitants in the Mississippi delta.

Recently the Chinese parents who have children have been interested in establishing a school of their own in which their children may learn not only the usual subjects taught in this country, but also the mudiments of Chinese history and art. The profect will soon be materialized under the leadership of $\mathrm{Mr}$. Joe Lett, Chinese merchant at Cleveland, Mississippi, graduate of Chung San University, Canton, China, and Rev. S.Y. Lee, missionary of the Southern Baptist Convention to the Chinese in Mississipp1. They have interested the Home Mission Board of the Southern Baptist Convention, the Mississippi state Govermment, the

32. According to a survey made by Dr. Eavenson, former missionary to Interior China, now pastor of First Baptist Church, Cleveland, Mississippi 
Chinese Nationalist Government, and many Chinese merchants in America in this pioneer educational institution in the South.

Already the first unit of the Chinese sckool, a compact and beautiful structure bullt of concrete blocks covered with 1vory stucco, is nearing completion. This building is being erected at a cost of $\$ 10,000$, all of which was ralsed among the Chinese merchants. The bullding will house 50 students and two teachers. Thirty-six students are already enrolled. Classes are expected to begin in the fall of 1938 with a staff of ten teachers, most of whom will be practice-teachers from the Delta State Teachers College, which has generously offered to cooperate with the sponsors of the project.

The second unit, a chapel of similar construction, w1ll provide an auditorium and classrooms for use by the day school as well as the Sunday school. The Home Mission Board of the Southerm Baptist Convention is planning to provide the funds for this building. It has been the privllege of the writer to participate in the planning and promoting of this project during the last three years.

V. THE MORAL PROBLEM IN CHINESE COMMUNITIES

There is no doubt that the chinese are not the "lily white boys clothed all in green" described in the old ballad "Green Grow the Rushes, $0 "$; but at the same time let us see if their moral character is notably different from that of any community of hard-working single men thousands of miles from home and uprooted from their natural environment, 
codes and moral sanctions.

The vices existing among the Chinese communities are largely characteristic by-products of abnormal communities in which men far outnumber women. They are evil. but pathetic efforts to provide a substitute for normal home 11fe. Economic Iimitations tend also to drive the Chinese Into parasitic and underworld employments such as gambling, bootlegging and narcotics. But it is interesting and encouraging to know that the percentage of the total Ch1nese population in parasitic occupations is diminishing and the reason for entering such occupations is changing, according to studies made by Professor Reynolds of Stanford.

"The old Chinese criminal tong members were in these underworld activities because they wished to be. They had no standards, they were simply bad Chinese. Now the jounger generation, with more or less conscious American standards, are being forced into such callings by economic necessity - and they are correspondingly 1088 happy in them."

\section{A. Gambling}

Perhaps the outstanding Chinese vice today 18

gambling. It takes the form of games such as fan-tan and pie-gow, and also of lotteries, a form of excitement dear to the chinese heart and not regarded by the low class Chinese in China as an evidence of moral turpitude. Professor Walter G. Beach of Stanford University says:

33. Reynolds, C.N., op. e1t., 1927, p. 151

34. Boach, W.G., oriental Crime in Califormia, 1932, p. 160 
"Gambling, as we term 1t, 18 for the Oriental a recreation and not primarily a feverish scramble for wealth."

and quotes with approval the words of Edmund Mitchell:

"A Chinaman in rare instances loses"all when gaming with his own countrymen; but, if this result does happen, he goes next day contentedly back to work and is not, like most ruined gamblers of European stock, permanently incapacitated for honest to11."

But the American attitude towards gambling is that it is dishonest because it involves getting something for nothm ing, that it breaks down habits of thrift and steady work and therefore results in a disintegration of personal morale; that it has an insidious habit-forming quality which tends to make those who indulge in it become confirmed gamblers and parasites upon society. Moreover, with the novice, it often leads to increasing ventures which, if successful, bring about the demoralization so apt to come from "easy money" and unearned, Irregular, highly variable incomes, or when unsuccessful, results in debt, or worse yet, stealing or embezzlement to cover 10s8es. For these reasons, and the added fact that gambling dens are centers where depraved and criminal elements gather and where other crimes are planned, gambling is regarded as ant1social and contrary to American moral standards.

Now it is a curious fact that these evil results, while not absent among the Chinese, are somewhat mitigated by restraining influences in Chinese character and custom. It seems paradoxical that the most hard-working, thrifty race on earth should also be the race most given to gam- 
blingl A psychological explanation would probably ile in the fact that, lacking sports and other forms of release from the tension of hard work and monotony, the chinese finds in gambling an emotional escape. He gambles primarily for fun and excitement and normally for small stakes.

An interesting combination of literature and gambling is found in the Chinese lottery, which is based upon a poem that contains one thousand characters, all different. This poem is akin to the first chapter of Genesis in that it sets forth the ancient Chinese cosmology and describes the origin of the earth and the seasons. The lottery t1cket consists of the first seventy-five words of this poem printed on a slip of paper. The buyer strikes out the ten words which he thinks will win. On the day of drawing the seventy-five separate words are all put into a box and shaken about a certain number of times, say twenty-five, and are then drawn out. If the holder has five of these words marked on h1s ticket he breaks even, if six he wins twice the amount he pald for his ticket, if seven he wins five times his original payment. One of the complications of Chinese gambling is that it seems to be heavily patronized by other races, Americans, Japanese, Filipinos, etc. The Americans especialIy seem to have a child-like trust in the absolute honesty of the Chinese lotteries.

B. Opium

Another Chinese vice is opium smoking. It ls true that Chinese have been reproached with the traffic in opiun 
and other narcotics, which has grown to tremendous proportions in recent years. But it must never be forgotten that opium is not a drug of Chinese origin. It was forcibly introduced Into Chine by the Dutch and British merchants jears ago. Poppy cultivation has been almost forced upon the Chinese. When the ChInese Government took steps to stop the cultivation of the poppy and the importations of the poppy product from the outside, the white race compelled the chinese to infure themselves by the use of opium so that they might get a profit derived from their infury. oplum formerly could be Imported Into the United States by paying a duty of $\$ 6.00$ a pound, but since 1909 its importation has been forbidden. of course, there has been smuggling, but the determined action against 1t - local, national and now international through the League of Nations - has resulted in greatiy reducing the amount of opium-smoking and driving what remains of it into hiding. The oplum dens are also very heavily patronized by other races. It has done more harm to other races than to Chinese themselves who seem to have possessed some degree of Immunity to opium's worst effects.

Professor Beach of Stanford, says,

"Undoubtedly the opium hab1t is health wrecking, as is any narcotic hab1t. The effects of narcotics are doubly pernicious, first in the creation of an unnatural craving, then, in the devastating after effects, causing a viclous c1rcle, leading generally to the muln or death of the victim." 36

35. Palmer, A.W., op. c1t., 1934, p. 24

36. Beach, W.G., op. cIt., 1932, p. 151 
The following is a case of an oplum investigation made by the federal government agents in Loulsville, Kentucky, during the flood, 1937 :

"A Chinese, docketed by police as Charles Woo Doo, 51, laundry operator, Wednesday faced a charge of violation of the Federal Harrison Narcotic Act growing out of the seizure of $\$ 500$ worth of 'smoking oplum' at the Rallway Express Agency, 550 South Fifth Street.

"Government agents said this was the first selzure of this type of narcotic in Loulsville.

"Agents reported the shipment was discovered after its arrival in a carton marked 'perishable' during the flood and sent to the city Hospltal, as were many other similarly marked shipments, usually containing foodstuffs, for use of patients.

"The package contained between 500 and 600 grains of the narcotic packed in tins inside a clgar box, agents sald. After 1ts discovery a card was sent to the addressee, 'Mr. Woo Brothers,' 732 south Fourth, and Doo was arrested Tuesday when he attempted to claim 1t.

"Doo, who said he was a naturalized citizen who served in the United States Army during the World War, told agents a former employee, who left the city about two weeks ago, had told him he expected a package and asked him to claim it and hold it for forwarding to an address he would advise later.

"Former Chief of Detectives William H. De Forester appeared for Doo and at his request the defendant was released under $\$ 2,000$ bond for hearing February 18."

C. Prostitution and Trade in Slave-girls

Due to abnormal conditions in Chinese communities,

In which men far outnumber women, prostitution has flourished in many cities where Chinese have settled. Many laboring

37. The Loulsv111e Times, Narch 15,1937 
Chinese waste their hard-earned money for such indulgence and thus transmlt venereal diseases from generation to generation. Slave girls, who brought $\$ 1,000$ before the exclusion law of 1882, ranged in price from $\$ 2,000$ to $\$ 3,000$ thereafter. A sidelight on the extent of this evil is revealed by the fact that more than 2,000 girls have found refuge in the Presbyterian Chinese Mission Home in San Francisco since it was founded in the early seventies. The work of Miss Donaldina Cameron in this connection will be referred to in the section which discusses the "tongs." Those who wish a more complete picture may well read the Ways of Ah Sin, by C.R. Shepherd, a Baptist missionary in California, and Chinatown Quest, the life adventures of Donaldina Cameron, by Carol Green W1lson. According to $\mathrm{Dr}$. Shepherd, he rescured during the year 1923-1924 twenty slave girls valued at a total of $\$ 110,000$. But the cond1tions are now much better, due to the work of Miss Cameron and the efficient cooperation of Inspector Manion of the San Francisco police.

\section{Tongs: Chinese Secret Societies}

Very little printed material descriptive of tongs has appeared in a form readily accessible to the American public. The few publications devoted to this subject have not been sufficiently comprehensive to enable the reader to gain a clear and definite understanding of these pestiferm

38. Shepherd, C.R., "Chinese Girl Slavery in Amerlca," Mission Revien of the World, Vol. 46, 1925 
ous and iniquitous institutions and their nefarlous pract1008.

\section{Meaning of the Word "Tong"}

Tong is a Chinese word meaning "assoolation," "society," or "club." It is also sometimes employed to express the 1dea of "party," in such Instances as the "Reform Party." In recent years, however, it may almost be said that the word has been taken over Into the English language particularly on the Paciflc coast - and to have come to be used exclusively to indicate certain obnoxious and dangerous organizations which exist in the Chinese communities in the United States.

\section{Tongs: Good and Bad}

It should be noted that the tong in itself is not necessarily criminal. Most tongs are entirely legit1mate - famlly, social, or business clubs which perform useful functions. They are composed of persons of the same surname or group of surnames. For instance, there is the Louls Kwong Fong Associations, with 1ts counterpart, the so Yuen Tong. Membership in this organization is open to all whose surnames are Loule, Kwong or Fong. Then there is the Lan Kwan Cheung Chu Association, with membership composed of persons whose surnames are elther Lan, Kwan, Cheung or Chu.

These Associations act as private courts to settle settle disputes, they serve in lieu of insurance or mutual benefit associations, maintain schools and provide for 
frlendly, social intercourse just as American clubs do. A visit to the palatial home of the on Leong Tong in Chicago, for instance, reveals a court and committee rooms, a shrine, and a school for 150 children. It is really a powerful merchants' club trying to serve the interests of the Chinese community. Nearby is the building of the Moye family - the leading clan in Chinese Chlcago. Its upper floor is devoted to a spacious room in which the most consplcuous object is a beautiful shrine to the ancestors. Here family counc1ls are held. The strength of Chinese social solidarity lies in these tongs or clubs which do a vast amount of good.

There are, however, criminal tongs which are equivalent to the "gangs" in American 11fe. They grow out of similar conditions and operate along much the same lines. A crimlnal tong is an organization of a criminal class of Chinese who want to do something forbldden by the law, which they do more safely and profitably through the cooperation and protection of a group than through individual criminal action. Nobody knows just how many of these criminal tongs there are, but an article by Edward A. Murphy, in the San Franclsco Bulletin for March 15, 1921, 11sted nine. Some of them, at least, are nation-wlde in their scope and operate In New York, Chicago, Philadelphia, Brooklyn, Newark, Cleveland and elsewhere and engaged in a bloody tong war as late 39

as 1927. The origin and early history of these criminal

39. The Ghicago Tribune, March 25, 2927 
tongs are somewhat difficult to uncover. According to Dr. 40

Shepherd, the Highbinder Tongs are not Indigeneous Chinese institutions. They originated on western soll and do not have any organic or spiritual connection with any organization existing in China. Those who are familiar with the history of the fighting tongs of America will be impressed by the marked similarity of many of their high-handed and bloody practices. There are two tongs in America which style themselves Freemasons. The flrst was originated in San Francisco in 1849. It is claimed today that this is not a Highbinder Tong. The second Tong is known as the Masonic Lodge. It is anything but a Highbinder Tong. Over the door of 1ts headquarters in many Pacific Coast cities is the sign "Chinese Freemasons." Its members wear the square and compass. Its headquarters are styled Masonic Temples. This Soclety is known the country over as one of the most powerful and bloody fighting tongs in America. Its power is tremendous and reaches out into practically every Chinese community in the United States.

During the decade $1880-1890$ tong wars reached a maximum in San Francisco, where scarcely a day passed that somebody was not killed. Even white people were killed by accident as shots were flying in all directions. One afternoon there were as many as seventy-five shots fired on the streets by one Tong against another.

40. Shepherd, C.R., The Ways of Ah Sin, 1923, p. 200 
The report of the sergeant in charge of the Chinatown squad at that time reads as follows:

"I went to Chlef Crowley and told him that I could do nothing; that there were no laws to cover these things. I sald that when any of these Chinamen commit deeds of violence they run into the numerous small alley ways of chinatown and get beyond our reach, and after being once lost sight of 1 it is impossible to identify them unless by some peculiar mark upon them. These societies are unlawful and organized for unlawful purposes. They do not recognize our laws, and to compete with them we have to go beyond our laws. I can put a stop to these societies if you will let me do it my own way. - Next I saw the Chinese Consul and he spoke to the Chief of Police, and also told me to use my own judgment; assuring the Chief that if he should be sued, he or the Chinese Government would stand the consequences. The Chlef sent for me and said that he thought my ideas were all right, and gave me permission to carry them out in my own way. I then went out and got seven or elght strong, healthy officers, and wo visited all these places, taking down the numbers and setting out in the night to get into the workings of these Societies. When I had everything arranged, I got sixteon men in uniform and a surgeon, and supplied all with axes. We marched from one to another of these soc1eties and literally cut them to pieces; we did not leave a bit of furniture five inches long in any of them. I suppose we broke up about $\$ 180,000$ worth of property. Some of these places were fixed up magnificently. Wherever we went we got arms, ammunition, bowle knives two feet long in blade, Iron bars done up in bralded cord, etc.; also chain and steel armour which they wear under their clothing, and which is utterly impossible to penetrate. of course, after we broke up their meeting places they could not meet. Among the better class of Chinese who belong to these Socletles through fear or for self-protection, we were held in favor for what we have done. They did everything they could to ald us. They could not meet me in Chinatown, but they came to my home in hacks at night to inform me where I could find these men. I was so well posted in the situation in Chinatown that they could not open their rooms or offices in any place. We 
broke up their josses - they always have josses in these places. One of them they brought from China. It was worth from $\$ 700$ to $\$ 800$. I broke up one of these and the friendly Chinese were superstitious that they feared I would die. I went around to all the stores, houses of prost1tution and places of that kind in Chinatown, and notified these people that if they were alding these Highbinder Societies in any way I would demolish their places. If they wanted protection I would give it to them. If one officer would not do I would give them forty; but if I found that any of them were paying to any of these socleties I would break up everything they had. In this way several of the socleties were driven out of town; and for about three years there was not a Chinaman killed in the city. If this method had been kept up we should not have had any more trouble. The reason it was not kept up was that suit was commenced in the United States Court against the Chief of Police and the raiding officers, and everybody who was concerned in these raids. The at torneys for these. Chinese Highbinders raised a large amount of money to carry on these suits and bothered the Chlef of Police a great deal. It kept us going all the time. The cases were first conducted in the local courts and then taken in the United States courts." 41

\section{The Commission of 1901}

Report of these conditions reached the ears

of the Government at Washington, and in 1901 the United

States Industrial Commission, appointed by the 57th Congress, included in its activities an investigation into the practices of the Highbinder Tongs, and other social evils existIng in the Chinese communities in America. J. Fndicot Gardner, who was at that time United States Chinese Inspector at the Port of San Francisco, testified before the Comm mission he had spent many jears in intimate contact with 41. Report of the United States Industrial Commission, 1901 , 
the Chinese in the United States, thoroughly understood the Chinese language, and was very familiar with the methods of the Tongs.

He stated that he knew that these Tongs were organdzed societies for the purpose of committing crime; that they exlsted on blackmail, on pay for protecting gambling houses and disreputable houses in general; that they took it upon themselves to try cases, to review judgments of the United States Courts with utter disregard to United States Laws, and that they nullified the decisions of the United States courts.

After thorough investigation of the situation, the Honorable Albert Clarke, Chalrman of the Commission, made his report to Congress. He concluded as follows:

"During my investigation of this subject a number of very prominent and wealthy Chinese merchants in the City of San Francisco visited me in my hotel; most of them coming secretly in the night time, . . everyone of these men substantlated what $\mathrm{Dr}$. Gardner had sald concerming the frauds comitted in the landing of coo11es. They insisted that if the Highbinder Societies could be broken up that the source of nearly all these frauds against the Exclusion Act would be removed.

"It is my opinion, after a most thorough and careful investigation of this subject, that if the country could be rid of this criminal class of Chinese, and the Highbinder Societies of Tongs permanently suppressed one of the greatest factors in the commission of fraud in the administration of the Exclusion Act would be eliminated.

"As a result of my investigation I have reached the conclusion that the only way in wh1ch this evil can be reached and the country rid of this vicious and disturbing element is for Congress to take the subject in hand. 
"The one thing which they fear above all others, holding it in greater dread than all of our laws, our courts and jails, is deportation to China. The purpose of the highbinder organizations is vicious and criminal. They should be suppressed by law of Congress, and membersh1p therein, or in any society having for 1ts purpose the commission of crime or the violation of our laws on the part of allens residing in this country, should render such allens liable to deportation."

After the report of this Commission, Congress, however, did not pass any legislation that would suppress these organizations.

A few years later, a group of ministers, educators, social workers, lawgers and public officials, both American and Chinese, who frequently had contact with Chinese affairs in America, met to discuss the matter and to find some way to cope with the situation which was steadily becoming worse. After much deliberation it was decided to make an effort to provide special legislation which would enable the Department of Labor to deal with the situation through a process of deportation. Accordingly the following proposed act was prepared for presentation to Congress:

AN ACT TO PROVIDE FOR THE DEPORTATION OF CERTAIN CHINESE PERSONS

"Be it enacted, by the Senate and House of Representatives of the United States of America in Congress assembled:

"Section 1. That any Chinese person, or person of Chinese descent, who is a member or assoclate of any tong, highbinder organization, society or association, including those incorporated in accordance with law, whose actual purpose, object or practice, wholly or in part

42. Shepherd, C.R., op. cit., 1923, pp. 207-9 
is the advising, encouraging, alding, abetting, countenancing, attempting, or engaging, either directly or indirectiy, in highbinder wars, homlclde, blackmail or the holding of women for prostitution, shall be deemed to be unlawfully in the United States, and shall, upon the warrant of the secretary of Labor, be taken into custody and deported to the country from which he came at any time after the date of his entry into the United States. Such arrest and deportation shall be at the expense of the appropriation 'Expense of Regulating Immigration (Chinese)'; provided that, pending the final disposition of the case of any person so taken into custody, he may be released under a bond in the penal sum of not 1088 than one thousand dollars $(\$ 1,000)$, with security approved by the Secretary of Labor, conditioned that such person shall be produced. when required for the hearing in regard to the charge upon which he has been taken into custody, and for deportation if he shall be found to be unlawfully in the United States.

"Section 2. That the Commissioner General of Imigration shall, under the direction or with the approval of the Secretary of Labor, establish such rules and regulations prescribe such forms of warrants, bonds, oaths, hearings, reports, entries, and other papers, and deta1l or appoint necessary officers, and shall from time to time, issue such instructions not inconsistent with law, as he shall deem best calculated for enforcement and carrying out the provisions of this act.

"Section 3. That any Chinese person or person of Chinese descent arrested under the provision of this act shall be adjudged to be unlawfully within the United Strtes, unless such person shall establish by affirmative proof, to the satisfaction of the secretary of Labor, whose decision, if adverse to such person, shall be final, his lawful right to remain in the United States; provided that no previous adjudication of such person's rights to be within the United States shall operate as a bar to the proceedings provided for by this act.

\footnotetext{
"Section 4. That this act shall take offect immediately."
} 
The machinery for the passing of this act was 2.1 prepared and ready to be put in motion when, for some reason or other, the whole project was abandoned.

\section{A Letter Giving the Instructions of a Fight-} Ing Tong to One of Its Highbinders

"To Lum Hip, Salaried Soldier:

"It has been said that to plan schemes and devise methods and to hold the seal is the work of the literary class, while to oppose foes, fight battles and plant firm government is the work of the military. Now this Tong appoints salaried soldiers to be ready to protect ourselves and assist others. This is our object. All, therefore, who undertake the military service of this Tong must obey orders, and without orders they must not dare to act. If any of our brethren are suddenly molested it will be necessary for you to act with resolute will. You shall always work to the interest of the Tong, and never make your office a means of private revenge. When orders are given you shall advance valiantly to your assigned task. Never shrink or turn back upon the battlefield. When a ship arrives in port with prostitutes on board, and the Grand Master issues an order for you to go down and recelve them, you must be punctual, and use all your abllity for the good of the Commonwealth. If, in the discharge of your duty, you are slain we will undertake to pay $\$ 500$ sympathy money to your friends. If you a re wounded a doctor will be engaged to heal your wounds, and if you are laid up for any length of time you will recelve $\$ 10$ per month. If you are maimed for Iffe and incapacitated for work, \$250 shall be paid to you, and a subscription taken to defray all costs of your journey home to China. Furthermore, whenever you exert your strength to kill or wound enemies of this Tong, and in so dolng you are arrested and imprisoned, \$100 per year will be paid to your friends during your imprisonment.

"Dated 13th day of 5th month of 14th year of Kwong Su.

(Seal of the Tong)."

43. Shepherd, C.R., op. c1t., 1923, p. 204 


\section{Its Present Activities}

It is the unanimous opinion of missionaries, educators, social workers and police officials that the Tongs constitute today the greatest single menace to the social, moral and industrial welfare of the Chinese in the United States. The Tongs are mainly responsible for the social ovils which exist in the Chinese communities. The following are some of their main activities:

a. The Illegal Landing of Chinese By the power of money, Highbinder Tongs have smuggled many Chinese into the United States. Wen and boys are landed as merchants' sons and as students by means of papers fraudulently obtalned. Girls and women are landed as wives, sisters and daughters, when in reality they are destined for Imoral purposes.

\section{b. Prostitution}

The trafic in young girls for immoral purposes is the most profitable industry of these tongs. It has been estimated by one who is close to the heart of the whole business and is absolutely qualified to know that there are several hundred of such young Chinese girls on the Pacific Goast owned body and soul by tong men, who, in turn, are protected by the Highbinder Tongs.

M1ss Donaldina Cameron, matron of the Presbyterian Home for Chinese girls, stated that she knew that many of the members of these Highbinder Tongs were engaged in the business of buying and selling young girls for immoral 
purposes.

"We know," she said, "of cases where the Highbinders have even stolen married girls from their husbands, after they have gone to small country places."

"I think," she sald "that quite a number come voluntar11y, never dreaming what their fate is to be; but I think, also, that a great many are landed against their wills. We never recelve a girl that the Highbinders do not hang around the house for a day or two, looking for an opportunity to get her away from us. They even follow us to church. Only two weeks ago they had a carriage standing at the street corner, hoping to get a girl that we rescued a short time ago.

"Numberless threatening letters have come during the years that I have been here; slipped in under the door, from Chinese, of course. One morning when the man came around with the newspapers he found a large dynamite cartridge about a foot long standing up against the front door, placed in such a manner that when the door should be opened the cartridge would fall in and explode. When the pollce were called they found that at all the basement windows similar cartridges had been placed. Nearly always when we rescue a girl these Highbinders hire an attorney, who serves on us a writ of habeas corpus; furthermore, they go into court and swear that the girl 1s the wife of some

44. Shepherd, C.R., op. c1t., 1923, pp. 204-205 
man whom they have there in court; and they so intimidate the girls that sometimes they get them to concur in the testimony, and thereby get them back."

\section{c. Commerclalized Gambling}

There are many commercialized gambling

houses in almost every Chinese community on the Pacific Coast with the exception of San Francisco and perhaps Oak1and. Roughly speaking, these houses may be classified under three heads.

First, there are places which are open only to those who are bona fide gamblers. No sight-seers, social investigators or missionaries can gain entrance. Some of these places have the appearance of small stores with shelves stocked with canned goods and other commodities; and back of these stores are large gambling halls. These places are usually guarded by at least one sly old watchman, who is seated behind the counter or on a chair near the door. Should there be the least move on the part of any one to load him to fear that a raid is to be made or that some curlous person is golng to try to force an entrance he will press a concealed button and ring the bell in the gambling house in order that the automatic doors may be locked and the gamblers notified.

The second kind of house has no watchman and little or nothing to indicate from the outside thet it is a gambling house; but on the door or window is an innocent looking plece of paper upon which are written four Chinese 
characters meaning "open for business today." One who cannot read Chinese passes this by without a second glance, but one who is able to do so knows that somewhere back of that store, butcher-shop or soft-drink stand are the gambling tables.

The third kind of house is the wide-open house. There is no attempt made to disguise or cover up the real nature of these places. The doors are wide open and any one can go in. At numerous tables the games are in full swing at most any time of the day or night. Plles of money are in evidence upon the tables around which are Chinese, Japanese, Hindus, Portuguese, and American men and women gambling to their hearts' content. The tongs are back of it all. They are organized for the purpose of protecting this sort of thing. They provide funds by means of which skilled attorneys are employed to defend them in the courts and cormupt police officials are bought off.

\section{d. Tong Murders}

During the year 1931 there were two

dozen tong murders in the Pacific coast states. There were only three convictions. Two were given the death penalty and the other life imprisonment. Tong wars are st1ll a perlodic epldemic. When they occur everything in the Chinese community is thrown into confusion.

6. What is the Remedy?

Mang things might be written in portraying the nefarious practices of these perniclous organizations, 
but sufficient has already been sald to convince the reader of the gravity and enormity of the situation and of the urgent need for a remedy. The question of importance is, what is the remedy?

Occasionally some newspaper gives sensational publiclty to these things; or there is a local clean-up due to the change in the personnel or policy of some pollce department; or public sentiment, brought to a head by some especially sensational development, demands a reckoning. But these things are only temporary. They are but sporadic efforts to alleviate a condition which has become too glaringly evil and anti-social. They are like cough-drops, toothache tinctures and soothing syrups which offer temporary rellef but do not undertake to cure the disease by getting at the root of the trouble. Until the power of the highbinder and of the fighting tong is broken, these social evils will continue to be the greatest menace to peace, property, and social and commercial progress in the Chinese communities in America. The task of blotting out this evil will be by no means an easy one; yet it is not impossible. Their organizations are not tolerated in China. In Singapore, Hong Kong and Canada the British Government is said to have eradicated these evils by suppressing the Highbinder Tongs. What China and Great Britain has done America certainly can do. The law-ablding, fustice-loving group of Chinese in America is earnestly appealing to the American people for a righting of these grave wrongs. Many Chinese are members 
of these organizations because, upon their own testimony, they dare not withdraw from them. They would welcome with refolcing any effort that is made to strike off the shackles which bind them.

Any effort to be effective, must involve more than mere talk. The Government of the United States should fearlessly and thoroughly investigate the whole matter of the activities of these secret societies and see that adequate legal steps be followed to cope with the situation. As America has dealt with the Black Hand and the Vendetta, so let her deal with the Tong and the H1ghbinder. 


\section{Chapter V}

\section{CHINESE STUDENTS IN AMERICAN IIFE}

(1) History of Chinese student Migration

(2) The Boxer Indemnity Fund and its Relation to Chinese Students Coming to America

(3) The survey: Distribution of Chinese students

(4) Organized Efforts on Behalf of Chinese students

(5) Chinese Students and National Crisis

(6) Chinese Students in American Iffe

(7) Career and Influence of Returned Students from America in China 
Chapter V.

CHINESE STUDENTS IN AMERICAN LIFE

The flrst word in the Analects of Confuclus, written over twenty-three hundred jears ago, 1s "Hsiao" which means "learn"; and, from the fourth centurg B.C. until the present day, learning has occupled first place in the regard of the Chinese. But for many centuries, the learning of the Chinese has been, in the main, scholast1c, and though pract1cal, Jet not concerned with science. Contact with the outer world, however, shocked them into the consclousness of the Insufficiency of the native culture and the need of sending students to study in the Western countries.

I. HISTORY OF CHINESE STUDENT MIGRATION

Students are on the march. From generation to generation the migrating tendency persists. The movement of Ch1nese student migration was started by Yung Wing, who was the first Chinese student to graduate from an American college and turned out to be a great factor in educating the Chinese In modern learning. He was supported by the Morrison Education Society, a missionary organlzation financed by funds raised in England for the purpose of educating Chinese youth in Christian service. He took his degree from Yalo, in 1854 ,

1. Carver, W.0., The Course of Christian Missions, 1932, p. 187 
and, upon his return to China, his ldeas of bringing Westerm oducation into his native land met with opposition on the part of Chinese educators and gentlemen of the Government. But by direct, earnest, and able work, he succe日ded in persuading two of the leading statesmen in the Chinese Government to send thirty Chinese students to America in 1872. Since then there have been thousands of chinese students pouring into American colleges every year, and all this morement is indebted to rung Wing. The students who came to study in America returned home to build factories, start rallroads, and open schools. They have become college presidents, engineers, business men, and all this is largely due to Yung wing.

Before 1910 a large number of Chinese students went to Japan. In recent jears, the number has been decreasing, due to unfortunate relationships existing between these two nations. However, a large number of these students have gone to other countries; namely, England, France, Germany, Belgium, Canada, Sweden, etc. Statistics avallable for students who have gone during the year 1934-1935 are as follows:

$\begin{array}{lr}\text { United States } & 115 \\ \text { France } & 105 \\ \text { Germany } & 84 \\ \text { Japan } & 83 \\ \text { Belgium } & 26 \\ \text { Fngland } & 25 \\ \text { Canada } & 4 \\ \text { Sreden } & 3\end{array}$

2. Young, Arthur A., "Yung Wing - First Chinese Student Argonaut to America," The Chinese Christian Student, Vol. XXV, No. 7, $1934, \frac{\text { P. }}{20}$

3. Rawlinson, Frank, China Chrlstian Yearbook, 1934-35, p. 245 
The total number of forelgn students in the Onited States has decreased sharply during the jears of depression. It was 10,394 in 1931-32; 8,220 in 1932-33; and 7,720 in 1933-34. The number has steadily increased, however, during 1937 and 1938.

The following table shows what a large proportion of foreign students in the United States came from oriental countries:

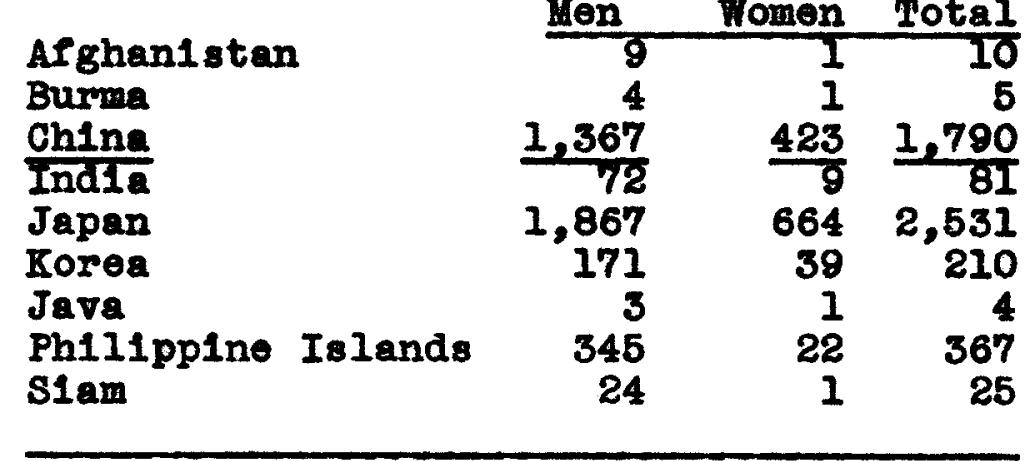

There are 10,093 students from 94 forelgn countries studying in the various colleges and universities of the United States, 1,790 of whom are Chinese. These "unoff1olal ambassadors," as the Committer on Friendly Relations Among Forelgn Students calls them, are here at a very impressionable period in their lives and may, therefore, become not only ambassadors of better understanding from Ch1na to the United States, but also ambassadors to China on the behalf of the United States.

II. THE BOXER INDEMNITY FUND

The reason why students from China lead all the forelgn

4. Hurrey, Charles D., The Unofflcial Ambassadors, 1938, p. 14 
student delegations except those of Japan is probably due to the Boxer Indermity Fund, which has made it possible financially for the Chinese Government to send many students to America for study. The history of the appropriation of the Boxer Indermity Fund may be outlined as follows:

A. 1900 - In the sumer of 1900 a rebellion broke out In China by a faction known as the "Boxers," which was united against all forelgners, Including Americans in China, and during which many forelgners were massacred and their property destroyed.

B. 1901 - In the so-called "Final Protocol of 1901" between the treaty powers and China, an indemity of approxImately $\$ 330,000,000$ for the Boxer outrages was levied on the Chinese Government, these funds to be secured from the custom revenue. The share allotted to the United States was approxImately $\$ 24,500,000$.

C. 1908 - On May 25, 1908, the United States Congress passed a joint resolution whereby the United States was to "remit" to China approximately $\$ 12,000,000$ or one-half of the Boxer Indemities allotted to the United States. The Chinese Government determined to use this money for the education of Chinese youth in American institutions. For this purpose, also, a college was founded in China to prepare such Chinese students who were to study in the United States. D. 1924 - On May 21, 1924, the Un1ted States Congress

5. Johnson, J.E., China Yesterday and Todar, 1931, p. 223 
Pramed another joint resolution whereby further Boxer Indemnit1es paid the United States together with pajments to be made in the future, were to be paid back to China to be used for work in education and culture.

\section{THE SURVEY}

A. Fore1gn Students in Colleges and Universities of the United states

There were, in the United States during the year $1937-38,10,093$ forelgn students from 94 countries of the world, according to the Committee on Friendly Relations among Forelgn Students, which has just made public its re6 port. Japanese students lead in number, with a total of 2,531. Second in rank are Chinese students, with 1,790 and Canadian students rank third with 1,615. The Committee Sound that there were 210 Korean students and 367 F1lipino students in the Onited States during this jear. Among the Furopean nations, Fingland has sent 238; Germany, 333; Russia, 77; Turkey, 76; France, 93; Italy, 53; Switzerland, 39; and Sweden, 31 .

A new Interest is envisaged in the increasing number of Latin American students coming to the United States, many on special fellowships. Cuba has 359; Puerto R100, 407; Panama, 77; Mex1co, 222; N1caragua, 15. The Comitteo states that the oriental tabulation in-

6. Annual Report of the Committeo on Friendly Relations Among Forelgn Students, The Chinese Christian Student, Vol. XXXVIII, Nos. 4-5, 1938, P. 5 
cludes Amerlcan-born students, of the Japanese totals, 772 are American-born Japanese, and of the Chinese totals, 620 are American-born Chinese. When these are deducted, there are 1,259 students from Japan; 1,170 from China.

B. Distribution of Chinese Students By States (In 10cal1t1es)

The Chinese student enroliment in American colleges and universities for the academic year 1937-38 has show a definite increase over the enroliments of previous jears. According to the figures, complled by the Chinese Students' Christian Association in its annual survey of Chinese student enrollment, the total enrollment for 1937-38 1s 1,790 , as compared to 1,733 for $1935-37$ and 1,414 for 1935-36. Th1s 1s an 1ncrease of 57 students over the past 7 jear.

The State of California, with forty institutions of higher learming, has attracted the largest state enrollment of Chinese students, 545. Second is New York with a total of 278, scattered through trenty-seven colleges and universities. Third is Michigan, with 176, enrollment in elght institutions, principally at the University of Michigan; and fourth is Massachusetts with 140, distributed among elghteen colleges and technical schools. It is interesting to note that not many Chinese students are studjing in the Southern States; the total number for the academic jear 1937-38 was only 87. States like Florlda and Ner Mexico have only one

7. He180, Y.E., Directory of Chinese Students in America, $1937-38$, p. 78 
Chinese student in the whole state and many, such as Alabama, do not have one single student. The Chinese students in the Onited States are enrolled in 275 colleges and universities, located in almost every state of the Union except a few Southern states.

The survey revealed also that there are approximately four Chinese male students to every one Chinese girl student, or 1,367 men to 423 romen. The universities that have attracted the largest number of Chinese students are: First, the University of California with a total enrollment of 191 students, 162 of whom are Amer1can-born. Next is the Un1versity of Michigan which leads in enrollment of Chinese students from China - a total of 165, of whom 28 are women. Columbla University is the third, with 96. It is followed closely by San Francisco Junlor College and New York On1versity.

Many university Registrars do not have the means to ascertain whether chinese students are American-born or not. Amerlcan-born Chlnese students are found, however, mostly in colleges and universities in the West; while the nativemborm Chinese students are concentrated in the Central and Easterm schools. Of the larger Pacific institutions, the Registrars have reported the following Amerlcan-born Chinese enrollment:

$\begin{array}{lr}\text { University of California (Berkeley) } & 162 \\ \text { University of Southern California } & 114 \\ \text { University of California (Los Angeles) } & 8 \\ \text { University of Washington } & 9 \\ \text { University of Oregon } & 8 \\ \text { Stanford University } & 7 \\ \text { Oregon State College } & 7\end{array}$


In the East, Columbia University reported 19 and the Univergity of Michigan 10. The relationships between the Amerlcan-born Chlnese students and those from China are not very harmonious. The conflict is due to the differences of cultural background; the American-born look upon the natives as products of a backward nation while the native-born think that those born in America are too Americanized and the occupational status of their parents - laundry owners and restaurant proprietors - a national disgrace. (Merchants, according to the old Chinese class system, are recognized as next to the lowest class while the scholars are recognized as the highest class).

C. Distribution of Chinese Students by Courses (1n fleld of studies

For many years, engineering has led in popularity among the dozens of courses that Chinese students specialized in. There are at 458 Chinese students registered in engineerIng courses - among them chemical, c1vil, electrical, and aeronautical engineering are the most popular. The interest In alpplane design and construction is evidence that china is going alr-minded. Second to engineering, are business and economics courses. There are 199 Chinese students registered In these courses. The third most popular subject 18 medical sclence, with 196, and fourth is education, with 86 enrolled. It is interesting to note that not many students are interested In social sclence or social work, but there is an increasIng interest in agriculture. Another interesting fact is that only two are taking up milltary solence - an indication that the Chlnese are not rar-minded people. 
TABLE XXI

DISTRIBUTIOY SUMARY OF CHINESE STUDMNIS, 1937-1938

(By States)

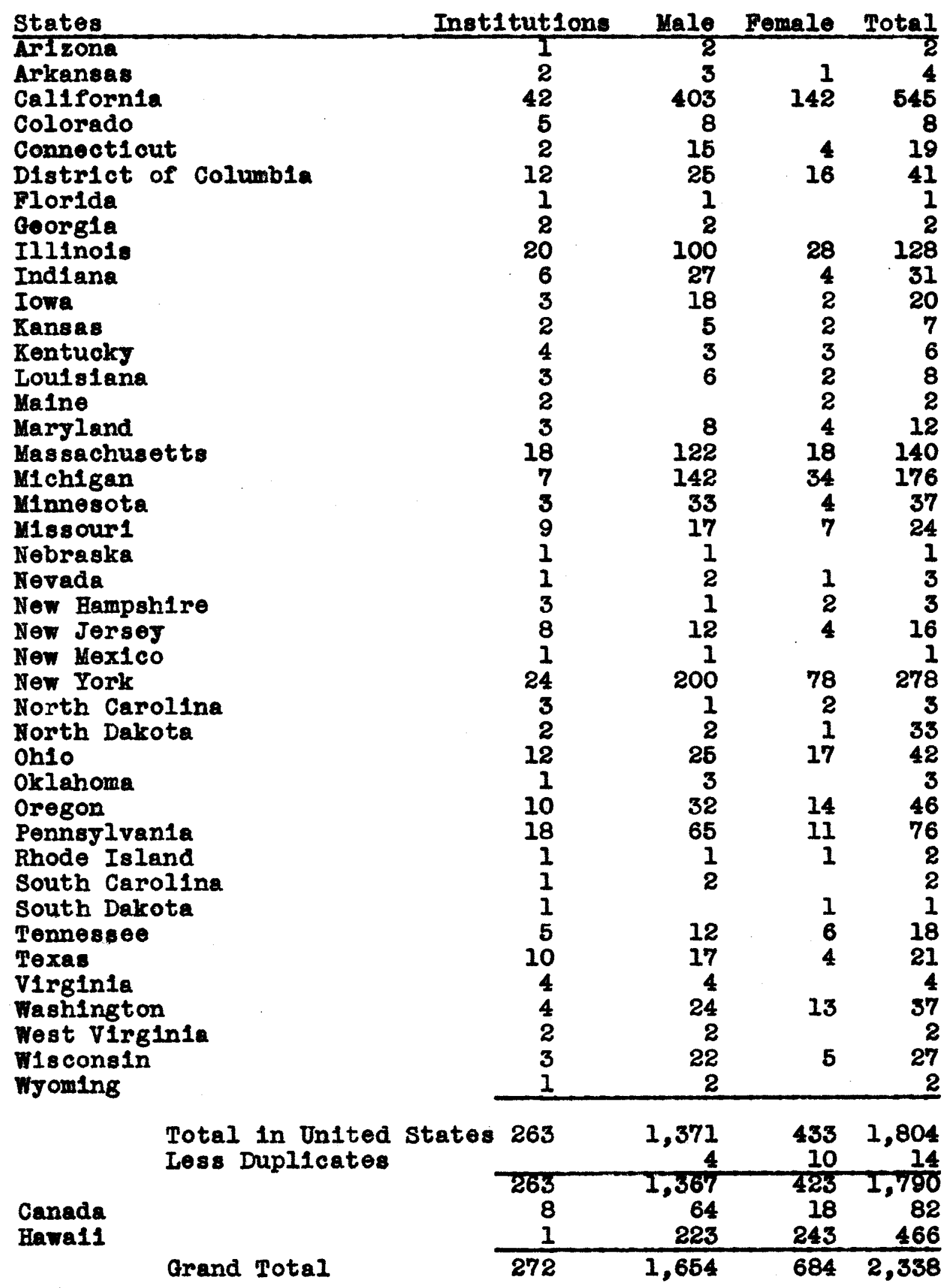

* Based on the Directory of Chinese Students in America, complied by the Chinese students Christian Association in North Amer1oa, Hew York, 1938 
TABIE XXII

DISTRIBUTION SUMMARY OF CHINEST STUDENTS, 1937-1938

(By Courses)

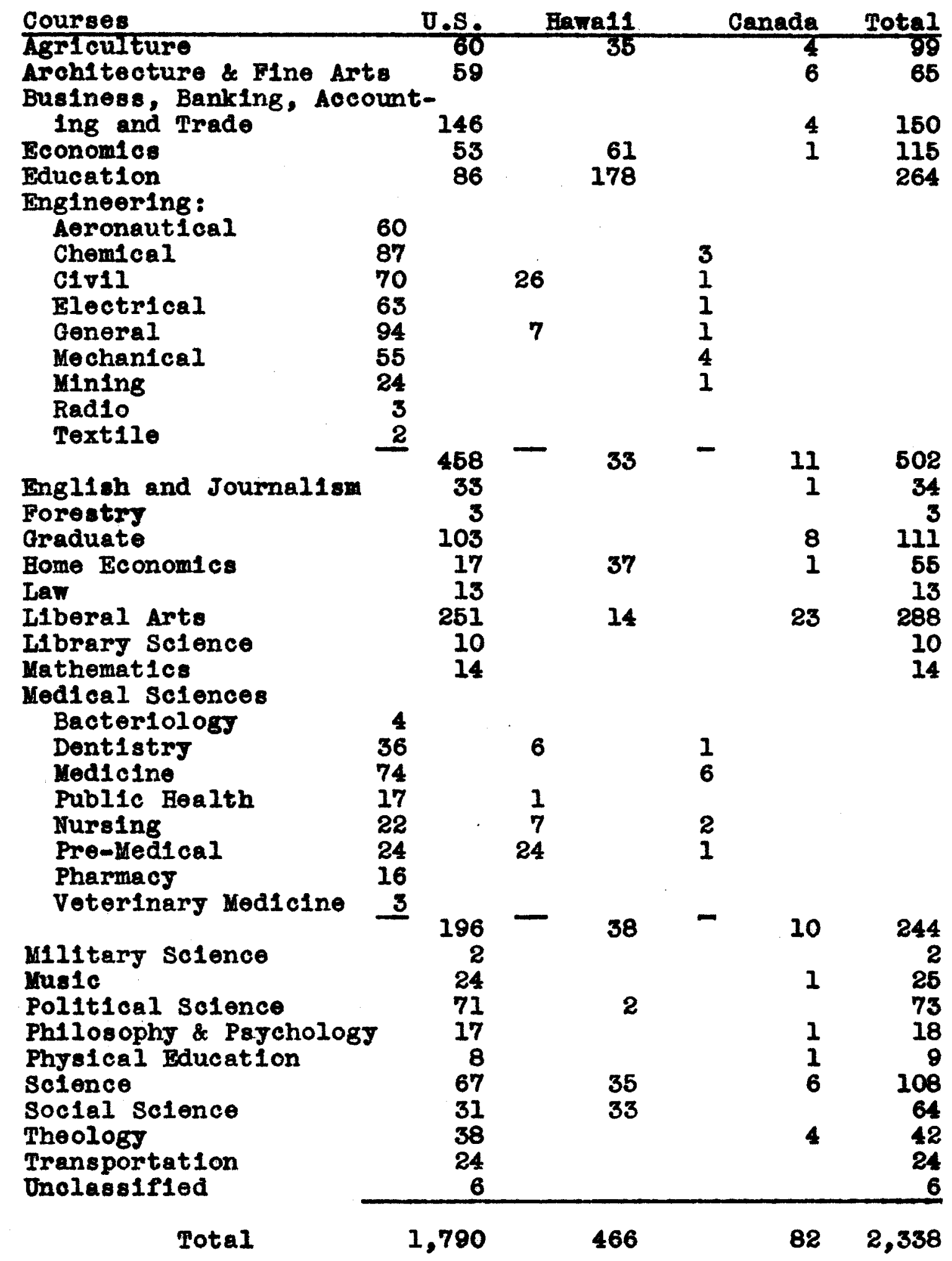

* Based on The Directory of Chinese Students in Amerioa. complied by the chinese students Christian Association in North Amerlca, New York, 1938 
D. Chinese Courses offered by American Univers1t10s Chinese courses, and courses in which China is covered in whole or in part, are being offered in gradually increasing numbers by American colleges and universities. Not long ago, one could have counted on one's fingers the colleges and universities which offered courses in whlch the Far East was the principal center of interest. Today, there are almost 500 courses offered in some 200 American colleges and universities which treat China, elther as a major subject or as a subject that occupies a significant portion of the $\operatorname{course}$.

Chinese courses are offered principally in the Departa ment of History, the Department of Political Solence, the Department of Art, and the Department of Religion and Philosophy. A few colleges, such as the University of Washington and the University of Michigan, are introducing Chinese race problems in their sociology departments. Pacific Coast institutions are tending to give the markets of Asla thorough treatmont in the business and foreign trade courses, and one university, the University of Southern California, has a course in which Asiatic journalism and the news from the Orlent ore exhaustively treated. 8

A survey conducted by the Chinese Students' Christian Association reveals that the following ten universities gave for the academic year, 1936-1937, the largest number of

8. Ib1d, 1937-38, p. 75-76 
courses in which China was treated in whole or in part:

$\begin{array}{lr}\text { 1. University of Southem Califormia } & 23 \\ \text { 2. University of Washington } & 19 \\ \text { 3. University of Califormia } & 18 \\ \text { 4. Columbia University } & 13 \\ \text { 5. University of Michigan } & 13 \\ \text { 6. Harvard University } & 11 \\ \text { 7. Yale University } & 10 \\ \text { 8. Pomona College } & 6 \\ \text { 9. Dartmouth College } & 6 \\ \text { 10. San Prancisco State College } & 5\end{array}$

Courses in the Chinese language were given, with cred1t, In 1936-1937 at Columbia University, the University of Washington, Harvard University, the University of Southern California, the University of Chicago, Yale University, Dartmouth College; at the University of Michigan, Chinese courses were given but without credit. Radcliffe College, which repeats the courses at Harvard University, may also be mentioned in this connection.

The Association has published in 1937 a report, by Arthur A. Young, entitled, Chine in the American University Curriculum, containing a complete directory of courses in which China is treated in whole or in part for the academic Jear 1936-1937.

E. Chinese on American Facult1es, 1937-1938

The Directory of Chinese Students in America, pub11shed by the Chinese Students' Christian Association, 1ists the Pollowing Chinese as members of American faculties for 1937-1938:

Chang, Tsung-Ch'1en, B.A., University of Chicago Chang, Yuen Zang, Ph.D., Visiting Lecturer in Chinese, University of Mlchigan

Chen, Philip S., Ph.D., Head of the Department of Chemistry, Madis on College, Madison, Tennessee

Chl, Chaoming, Ph.D., Lecturer on the Far East, New School of Soclal Research, New York Clty 
Chlu, A. Kaiming, Ph.D., Lecturer on the Chinese Language and Ilterature and Ilbrarian of the Chinese and Japanese Library of the Yenching University at Harvard University

Cot'ui, Frank, M.D., Associate Professor of Surgery, New York University College of Medicine

I1, Fang-Kuel, Ph.D., Visiting Professor of ChInese Lingulstics, Yale University

Mah, N. Wing, Ph.D., Assistant Professor of Pollt1cal Science, University of California

Pan, Stephen Chao YIng, Ph.D., Lecturer in Polltical Solence, Providence College

Sha, Chin Pe1, Associate in Oriental Languages, University of Callformia

Tang, Kwan Yau, Ph.D., Assistant Professor of Electrical Ingineering Ohio State Oniversity

Wang, Chl-Chen, A.B., Lecturer in Chlnese Languages and Curator of the Chinese Collection, Columbia University

We1, Franc1s Cho-Min, Ph.D., Visiting Professor of Ethics, Yale University

Weng, Tu-Chien, M.A., Teaching Fellow in Chinese, Harvard University

Wong, Bing C., Ph.D., Assiatant Professor of Mathematics, University of California 9

IV. ORGANIZED EFFORTS ON BEHALF OF THE CHINESE STUDENTS

A. The Chinese Students' Christian Association in North America

Under the fostering care of the National Y.M.C.A.

and the Y.W.C.A.'s Committeo on Frlendly Relations Among Forelgn Students, special organizations with secretaries of thelr own race have been bullt up among the Chinese, Fil1pino, Japanese, and Korean students. The Chinese students ' Christian Association in North America was founded at Colgate University, Ham1lton, New York, on September 2, 1909, under the sponsorship of the Committee on Friendly Relations Among Forelgn Students. The purpose of the Associa-

9. The Chinese Christien Student, Hs1aO, Y.E., "Chinese on smer1can Faoult108, "V01. XXVIII, No8. 4-5, 1938 , p. 8 
tion is threefold: (1) to organize all Chinese students, especially Christians, into cooperative efforts; (2) to build strong moral character and to foster the spirit of self-sacrifice; (3) to understand American life and society, and to interpret Chinese culture and civilization. The membershlp is of two kinds: active and cooperative. The active membership is limited to Chinese students in sympathy with the purposes of the Association; while any person, not a student, elther Chinese or Americans or other nationality, Interested in the work of the Association may become cooperative member.

To members and non-members, the Chinese students'-Christian Association renders a variety of services. These include the following:

To Students Entering Schoola: Advice and Information are given about colleges, entrance requirements, courses of study, faclilties for research, expenses, living facilities. It introduces students to Chinese groups and American friends. When requested, it meets new arrivals at port and rallway stations.

To Students Returning Home or Going to Europe: It gladiy assists in securing rallway and steamship tickets, making reservations, visaing passports, forwarding baggage or books, purchasing travellers' chocks, etc. To those goIng home by way of Europe, it will help arrange 1tineraries, supply letters of introduction for visits in Europe, and in general, place at their disposal friendiy assistance not 
eas11y ava11able.

To Students Wishing Ma11 Service: The Chinese Students' Christian Association $\mathbf{w 1} 1$ receive and forward ma1l anywhere. Students, uncertain about their address, find this service useful. To others wishing to locate a Chinese student in America or to contact one in China, this service Is also avallable.

To Students Wanting Other Services: The Chinese Students' Christian Association will help buy books or typowriters, for instance, at considerable saving. It will assist graduates in securing, In China, teaching positions, or other employment for which they are especially trained. Speakers on China: Colleges and universities invite the Association to provide speakers on subjects concerming China. Arrangements are also made for prominent Chinese visitors, as well as student speakers, to speak on China in different parts of the country. Through cooperation with allied student organizations, Chinese Students' Christian Association participates in many conferences, both international and national, every year.

Publications: The Chinese Christian Student is published monthly during the school year as the offlcial organ. The Chinese Students' Christian Association also publishes a Chinese Students' Directory in America. The publication Is in English.

The General Secretary: The secretary for Chinese stum dents of the Committee on Friendly Relation Among Foreign Students serves the Chinese students' Christian Association 
as its general secretary. Mr. Y.E. Hsiao, a graduate of the University of Shanghal and also Columbia University, is at present serving in this capacity, with his central office at 347 Madison Avenue, New York, New York. H1s chief duty 18 to execute the program of service of the Association and to visit the different student centers throughout the country, to establish new units, and advise organized units, and to render necessary a1d.

The Association charges no membership fee but takes voluntary contributions. The budget for fiscal year 19361937 was as follows:

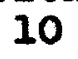
10

Estimated Income

"Balance on Hand
Subscriptions
Advertisements
Amount to be Raised by Contribut1
Estimated Expenditu
Chinese Christian Student
Field Work
Central Executive Board Meeting
Postage and office Supplies
Departmental Expenses
Pinancial Campaign
Chinese Student Directory
mergency Ioan Fund
Special Projeots
Mlacellaneous

Chinese Christian student Field Work

Central Executive Board Meeting

Postage and office Supplies

Departmental Expenses

Financial Campaign

Chinese student Directory

Special Projects

$\$ 1,500.00$

775.00

70.00

205.00

130.00

50.00

300.00

150.00

200.00

$-50.00 \quad \$ 3,430.00^{n}$

The salary and office space, telephone and stenographer for the general secretary, is provided by the comittee on Friendly Relation Among Forelgn Students, supported by an ondowment fund, largely donated by John D. Rockefeller, Sr.

10. The Chinese Christian Student, Vol. XXVII, No. 10, 1937, 
The Chinese Students: Christian Association is responsible for the other expenses connected with its work. It is an autonomous organization enlisting the active support of Chinese students and friends, having the advantages of an advisory committee made up of Americans who have been in China. The Association is governed by a central executive board, elected by the students and members annually. There are also three departmental committees, serving the different districts where the Chinese students are found; namely, Eastern, MId-western, and Western. No committee has been organized to serve the Southern states as yet, because of the limited number of Chinese students studying in Southern schools.

B. The Chinese Students' Association of North America Owing to the indifferent attitude toward Christianm ity and the stimulation of the national crisis in China, a group of liberal minded students in Chicago, mostly government students, organized in 1935 a separate association, called The Chinese Student Association of North America, with 1ts headquarters at 141459 th street in Chicago, This Association is primarily an anti-Japanese organization, gaining little support from the students because of its radicalism. The Association publishes a monthly paper entitled the Chinese student, a magazine printed both in Chinese and English.

The Association holds a general convention every two years. The last convention was held in Chicago in the sum- 
mer of 1935. More then one hundred delegates attended tho convention.

C. Chinese Student Association of the South Chinese students studying in the southern colleges and universities are relatively few. For the jear 1937-38, there are only elghty-seven enrolled, elghteen of them in Tennesser, twenty-one in Texas and six in Kentucky. In the summer of 1937, the first effort was made to unite these Chinese students. The three-day conference at the Hotel Peabody, Memphis, Tennessee, August 24-26, marked the beginning of unified Chinese student $11 f \theta$ in the south, and the Chinese Student Assoc1ation of the South was organized. The Association has a membership of over fifty and publishes a b1-monthly pamphlet, entitled Chine Calls. A convention will be held once a jear for the election of officers and transaction of business. The Association cooperates with other Chinese student Associations; namely, the Chinese Students' Christian Association, the Chinese student Association of North America, etc. Delegates were sent to these student conferences at Chicago and New York in the summer of 1937 for cooperation and friendship.

D. Chinese University Alumn1 Associations

Besides these combined student associations, there are also many Chinese University Alumi Associations, organized by the sons and daughters of Christian colleges

12. Kunhing, William, Ching Calls, February, 1938, p. 7 
and universities in China. The most prominent among them belng IIngman UnIversity Alumi Association, the University of Shanghal Alumni Assoclation, and the University of Nanking Alumn Association. These Unlversity Alumi Assoc1ations have their dinners, dence parties, at special occasions such as Christmas, and monthly gathorings in members' homes. The University of Shanghal has about fifty alumni in the United States, twenty-five of them in the city of New York; Yenching University has seventy and IIngnan University, fifty.

Outside of the Christian colleges there are Tsing tha College Alumni, Nanyang University Alumni, Futan University Alumni, and also Nanka1 University Alumi, scattered among var1ous campuses.

E. Other Student Comittees and Organizations Besides the above-mentioned organized effort on the part of the Chinese students in securing unity and cooperation, there are also many other service organizations developed by Americans who seek to make the best in Amer1can Iffe available to students from foreign countries and who belleve that the presence of forelgn students in the United States offers opportunities for international friendship and experiences that are steps in the direction of world peace and understanding. These organizations are "The International student Committee," "Committee on Friendly Relations Among Foreign Students," etc. 
1. The International Student Comittee

The International Student Committeo 18 the result of a movement started twenty-five years ago by the Y.W.C.A. at a time when women students from forelgn countries began to come to the United States in large numbers. The desire to assist these students in their first experlences of American life developed 1nto the organization of a joint committeo of Amerlcans and forelgn students. Its policies and methods have been directly influenced, therefore, by forelgn students themselves, who, belleving in the aims of the Committeo, have shared the work with American members of the Comitter. The Committer assumed respons1bility for carrying on the work as an independent organization in 1933 and has had its headquarters at International House, New York City, since September, 1936. The work of the Committeo is supported entirely by voluntary contributions.

The Committee works with students of all races, all creeds, all nationalities. There are nearly one hundred former student members of the comittee living in eighteen countries, who assist the present Committee in 1ts work here and abroad, and the Committee is constantly in touch with educational and social agencies throughout the world. The following summary is tabulated from the reports supplied by colleges and universities where the forelgn women students are located. There are at present 1,039 students of foreign birth studying in 37 states and the District of 
Columbia, and representing 64 foreign countries. It is oncouraging to know that China has the second largest representation, ranking next to Canada.

\section{TABLE XXIII}

FOREIGN WOMEN STUDENTS IN THE UNITED STATES, 1936-1937

Africa
Alaska
Arabia
Armenia
Australia
Austria
Bahama Islands
Belgium
Bermuda
Bolivia
Braz1l
Bulgaria
Canada
Canal Zone
Ch1lo
Chine
Cuba
Czechoslovakia
Denmark
Danzig
Fgrpt
Fngland
Finland
France
Germany
Greece
Haiti
Hawal1
Holland
Honduras
Hungary
India

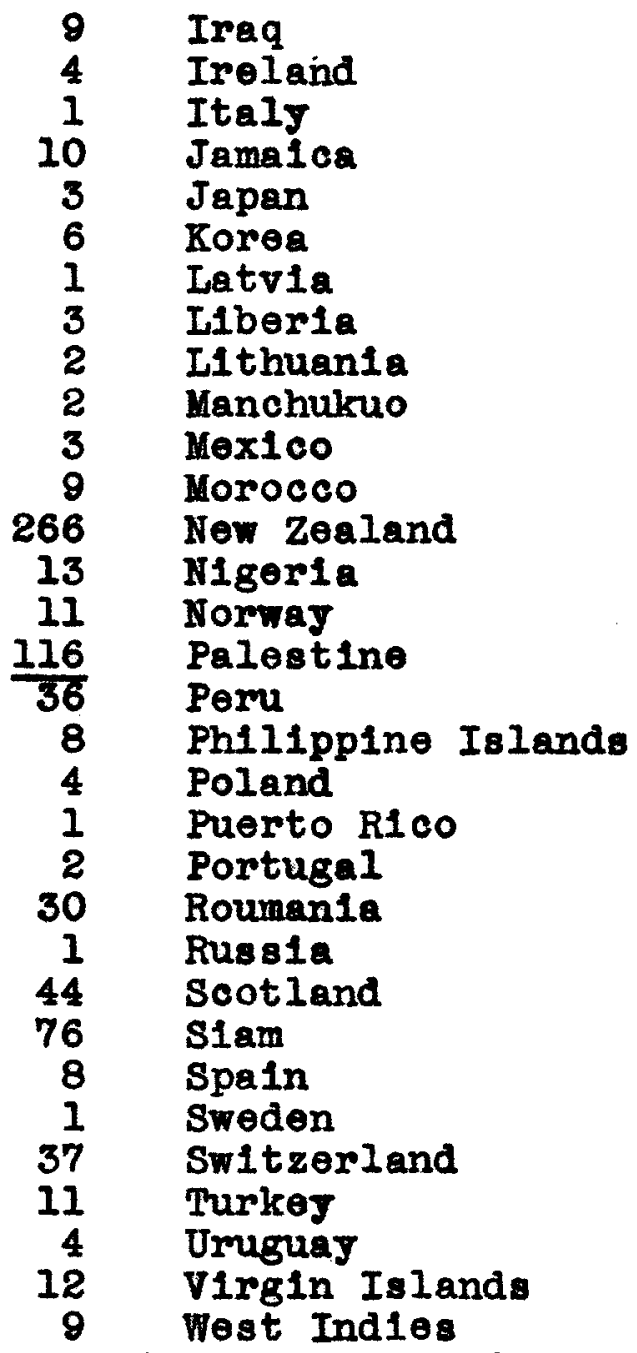

Number of countries represented 64

Total number of students $\quad 1,039$

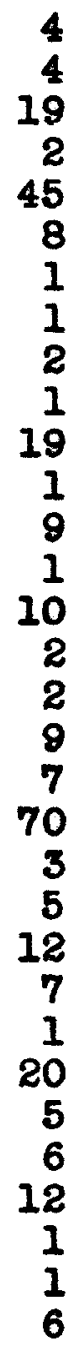

* Based on the Annual Survey conducted by the International student Committe日, New York c1ty, New York, 1936-1937 


\section{Committee on Friendly Relations Among Fore1gn Students}

The Committee was established in 1911. Its central objective is to promote international friendahip and understanding through friendiy contacts between Americans and the student ambassadors, men and women, from other lands. To this end the Committeo maintains a staff of nine secretarles; four of these secretaries are Orlentals - a Chinese, Japanese, Filipino, and Korean. Each Orlental secretary serves his fellow nationals in the United States and is rem sponsible for a national association among them. Monthly bulletins are published by these four oriental groups, containing news 1tems and frank expressions of opinion by students from the Far East. An annual census 1s compiled of all fore1gn students in the United States, and each of the Orlental groups publishos annually a directory of its own students.

Members of the otaff of the Committee travel extenarely in the United States, Canada, and throughout the world, keeping in contact with prospective as well as former students in the various countries. By this means it is possible to ascertain the trend of thought and action among students in all lands. Arrangements are made to meet now students at the steamship pler, if they desire; guldance 1s given with reference to travel in the United States, onrollment in American colleges, opportunities for visiting Amor10an industries and institutions. Many forelgn students are 
assisted in attending surmer camps, where they moet young people of America in very helpful program of international education. Many deputations are organized, composed of the ablest foreign students capable of addressing American audiences. Each year 11terally hundreds of American clubs, churches, and various associations are glad to obtain the services of forelgn student sperkers.

In times of depression or other calamity, the committeo has rendered a special service to forelgn students who were stranded in this country. Between 1932 and 1934 the Committeo cooperated in raising and expending over $\$ 12,000.00$ and thus assisting more than hundred and fifty forelgn students of first class ability either to return to their native lands or to complete their year of study in this country.

Many hundreds of letters of introduction are given each year to foreign students who may be travelling in the Unlted States or golng to Europe. Officers of the Committee and staff are maintained at 347 Madison Avenue, New York City, and there is close cooperation betweon the Friendly Relations Comnittee and the International Young Men's and Young Women's Christian Associations and the various churches and Missionary Boards.

Information is given concerning the number and distrin bution of forelgn students in the Onited States to all offloes of diplomatic and consular representatives in the United states. Information is also supplied upon request to various publications, schools, and olvic organizations. 
In the early post-war jears a spocial committeo was sponsored in order to ald Russian students to complete their education in this country. This organization was incorporated as The Russian Student Fund, and rendered substantial Financlal assistance to fully seven hundred students from Russia who could not return to the1r native land and otherIse would have had no opportunity to complete their educat1on. The majority of these students have now become Amer1can citizens.

Through the intervention of the Comnittee, American industrial leaders are always glad to extend courtesy to forelgn students v1siting their various industries. In some Instances opportunity has been given to foreign students for summer employment and obtaining experience by working in American Industry.

The ceneral Secretary of the Comaltteo addresses conventions and conferences, college assemblies and similar meotings, on the significance of forelgn students in AmorIca's international relationships.

v. CHINESE STUDENTS AND THE NATIONAL GRISIS

The Chinese students are a warmtorn generation. From the time the Republic was founded in 1911 down to the Japanese conflict of 1937 , the students have had to face the 1ssue of recurrent war and national salvation; and they have not flinched in the face of duty.

Like European students they are politically minded. The national crisis provided them with opportunity to express 
their patriotic consclousness. It is nothing new for ch1nese students to project their ideas and activities on the national screon.

Since the eventful night of July 7, 1937, at the Marco Polo Bridge, the Chinese students in continental United State have plunged themselves into various patriotic activIt1es and cooperated with the chinese merchants in ralsing the "National Emergency Fund," which has reached the sum of $\$ 4,000,000$. National emergency committees have been organ1zed in every city and town where Chinese students are found to arrange for addresses and talks, given at meetings of various fratermal, civic, social, religious services and romens' groups in the comounity.

Perhaps the most vigorous patriotic activity among ChInese students is their agitation for an economic boycott of Japanese goods. "Don't buy Japanese Goods," "Quarantine the Aggressor" are the slogans found on many university campuses Where Chinese students are enrolled. For Instance, Northwestern University sorority girls have started a movement to boycott Japanese goods. They hope to enl1st 1,500 others. Comeds of the School of Education of New York Unlversity stripped their shapely legs of silk stockings and drew on hose of wool. All these activities were inspired by the agitation of Chinese students on their respective campuses. Student conferences, held in different parts of the country, have centered their discussions on the survey of the sinom Japanese conflict and sought to form cooperative efforts for 
China's national salvation. At the Third Annual Convention of the American Student Union, held on the Vassar College campus at Poughkeepsie, New York, resolutions were adopted to aupport a program that will make the United states a genuine and active force for peace and to reject pacifiam by taking immediate steps to restrain aggressor-nation by economic boycott. One of the slogans adopted at the Convention was, "If jou wear cotton, Japan gets nothing." This was done through the influence and agitation of the Chinese student delegates attending the conference.

As a result of the war in China, there are many Chineso students in America today who are in desperate financial neod. Many have been cut off from all communication with their relatives in Chine and their remittances from home have been interrupted. At Columbia University, twelve are known who need Immediate funds for living expenses. Stum dents on other campuses are in a similar plight.

Students from war-torn provinces of Hope1, Kiangsu, Cheklang, Shangtung, Sulguan, are the most hard hit, as allowances from their local Governments have not arrived. Efforts are belng made by the various student organizations to raise funds to tide over the Tsing hua indemity students whose regular allowances, depending on the customs recelpts, have been seriously affected. Delays on tuition payments heve been granted by Columbia and other universities. A

13. Cour1er Journal, Lou1sv1110, Kentucky, Dec. 31, 1931 
Loon Fund Combitteo, to ald Chinese students during this crisis, is in process of organization, through Y.E. Hs1ao, general secretary of the Chinese Students' Christion Assoclation.

\section{CHINESE STUDENTS IN AMERICAN LIFE}

In the early days, the Chinese students were rebuffed from door to door, unable to find lodgings in American col14

lege towns. TIm Tleh, for Instance, went to Pullman, WashIngton, to attend the state college; but, even after five or six days of searching, no door was open to him. So the Y.M.C.A. secretary finally let him sleep in his office and this led to the foundation of an International club for foreign students. A leading Chinese doctor on the Pacific Coast still remembers how as medical student in an eastem city he was refused a room at a large Y.M.C.A., built especially for students.

Now the situation has been changed and much sympathet1c interest has been displayed by Christian America in her foreign student guests. The great International Houses in Ner York, Chlcago, and Berkeley are open to all regardless of race, color or creed. They are like great college dormltories with all the appolntments of a modern club. Each House is managed by an executive board and staff; approxImately 500 residents from fifty different countries, both men and women students, are accommodated in each bullding.

14. Palmer, A.W., Orlentals in American Life, 1934, p. 190 
They are centers of delightful activity. Weekly Sunday evening suppers are arranged, and a varlety of forums, ontertainments and social affairs constitute a rich program.

The Chicago Church Federation each year gives a forelgn students' dinner at which some ten or twelve hundred forelgn students are invited as the guests of the church people of the city who preside at the various tables. Many homes are opened in this way and many invitations to Thanksgiving or Christmes dinner or to speak before church groups, grow out of this simple friendly contact. All over America not only churches but Rotary International, Women's Clubs, Peace Socleties, and other clvic organizations hold out a hospitable hand to the students away from home. Invitations to participate in their activities and to share in their membership have been accepted by hundreds of the ablest students from all lands.

Brent House, near the University of Chicago, is a shinIng example of American hospitality to Oriental students. It Is a beautiful, homelike house, in the midst of a lovely garden which was given in 1930 as a national club for conPerence and devotion the gift of the Women's Auxiliary of the National Counc1l of the Eplscopal Church, and is maintained under their direction. Around it there has been created a Prlendly and homelike atmosphere. It 18 a home for the bullding of frlendship and understanding among peoples of different nationalities and races through religlous fellowship, Intellectual activities and social contacts. Here conferences of Orlental and other students have been 
held from time to time, here distinguished speakers from the orlent have been heard, many discusslons and meetings have been conducted by outstanding American religious and educational leaders. The home is always open as a frlendiy conter of Christian fellowship and, in a single year, drew over three thousand personal interviews and visits from students, ent1rely aside from organized conferences.

There is, however, only one Brent House in the whole United States. Many university campuses do not have such fac1lit1es. Certainly a Brent House, or its equivalent on a smaller scale, adjacent to overy university campus in Amer1ca, would change the returned student into a friend instead of a critic and a cynic, which he too often becomes today. Over the door of International House in New York 18 carved "That Brotherhood May Prevali" and over a door of the International House in Chicago is a Latin motto - Nemo Solus Sat1s Sapit, which may be translated "No one is sufficient unto himself," or, put into the vernacular, "No one knows enough to do the job alone." If the forelgn students can carry home these 1deals from America it will be a better day for all mankind.

VII. CAREER AND INFLUENCE OF RETURNED STUDENTS FROM AMERICA IN CHINA

Returned students from America are found today in the far corners of China. As a group, they enjoy an enviable reputation. Many of them have become premiers, ambassadors, financlers, college presidents, engineers, etc. They have 
contributed a great deal in the bullding of the Ner China. It would be grandy inspiring to know a few significant American graduates. For instance, in diplomacy and politics, graduates of American universities are very influential in China. Among the outstanding diplomatic and political leaders in China are found T.V. Soong, of Harvard; H.H. Kung of Oberlin, Premier of the Chinese Nationalist Government; C.T. Wang of Yale, Ambassador designate to the United States; W.W. Yen, University of Virginia, and recentiy Ambassador to Russia; Afred Sze of Cornell, former Ambassador in Washington; Wellington Koo, Ambessador to France.

In the fleld of education, hundreds of the professors, school superintendents, deans, and presidents throughout China take pride in chatting about their student days in America. The presidents of f1ve leading Christian Universities In China are graduates of Columbia University and the University of Chicago.

The cause of public health has been advanced in China by such leaders as Dr. J.H. IIn of Harvard and Dr. Ilea Teh of Johns Hopkins. Notable Indeed in the fleld of religion and social service are the contributions of David rul of Harvard, for many years general-director of the Y.M.C.A. of China; Y.Y. Tsu from Union Theological Seminary, Secretary of the National Christian Council of China; and "Jimmy" Ien from Yale, leader of mass education.

As interpreters of Oriental civilization and culture, there are T.Z. Koo, IIn Yutang, Hu Shih and many others. 
Indeed the cause of world peace has been strengthened by the contacts which these Chinese students, who have become today leaders of the Chinese nation, have made here in America. They all enfoy telling their friends of their happy days as students in America and their gratitude to America for the training they have recelved. There are, however, a few rom turned students, who have been "too Americantzed," and thus render little service to their native country. They prefer staying in big offices and drawing rich chocks to service and sacrifices. They have been quite a disappointment to the Chinese people. There are many opportunities todey in China which call for ploneers, builders, and, above all, those who are willing to do "dirty work" and remain unknown heroes. 


\section{Chapter VI}

THE FUTURE OUTLOOK

(1) Can the Chinese Be Assimilated?

(2) The Conquest of Racial Prejudice

(3) How Can the Social Workers Help?

(4) The Economic Outlook

(5) A Final Word 
Chapter VI.

THE FUTURE OUTLOOK

As one looks into the future and asks what wi1l be the outcome of the Chinese immigrants in America, two possible solutions suggest themselves.

The first possibility is the development of an Oriental caste, a community which lives within or beside the American community, but as a separate entity, similar to a bullet or other forelgn aubstance lodged in the human body; if it cannot be absorbed, it may find the tissues bullding up a wall or what is called a cjst of tough resistent material around It and there it may remain for years - in the body but not of 1t. This might happen, conceivably, with the Chinese in America. They might become like a caste in India, restricted to certain occupations, denied intermarriage and conm sidered socially "untouchable," except at certain strictly 1imited points of contact. This has been practically their stuation up to date, as it is the situation of every nerlyarrived race in America for a generation or two. But will it become permanent? If it does, it w11l be a decidedls unAmerican arrangement and will involve some real difficulties with respect to the stab1lity and progress of the nation. The other alternative is that they w111 gradually overflow the walls which hem them in and more and more become 
just a part of the whole American community. In so far as they do not stay in Chinatowns but spread out across the country th1s process will be accelerated. Such a process is described by sociologists as "Americanization" or "Assimilation."

\section{CAN THE CHINESE BE ASSIMILATED?}

Wuch of the argument against Chinese 1migration has been in terms of whether or not they can be assimilated. During the days of agitation for restriction of Chinese imigration, it was maintained by many that "the Chinese cannot be assimllated." They came to American shores and remained as "birds of passage" only to return to their native countries, carrying their earnings back with them. They had no intention of making their homes in America and no real interest in the preservation of American Institutions and standards. Such attitudes are being c1ted today by those who are opposing the granting of a quota to the orientals. What does the term "Assimilation" or "Americanization" mean? According to P.K. Hitti, Americanization "1s Invisible and subtle, if $1 \mathrm{t}$ is to be real and enduring .. Donning American clothes and eating American food does not constitute Americanization." It means "divesting one's self of a cortain deep rooted patrimony of 1deas, sentiments, traditions, and interests, and an acceptance of, and participation in, a certain new spiritual inheritance. Such a thing cannot bo

1. H1tt1, P.K., The Syrians in America, 1920, p. 99 
accomplished completely in one generation. Even the second generation among immigrants cannot be fully assimilated." Assimilation, according to E.M. Boddy, a Los Angeles editor, means "the process by which an allen people are taught to adopt the customs, practices and mode of living prevalent in the country in which they reside." In other words, It is a cultural process, which implies the acceptance of the 1deas, attitudes, customs, and traditions of the new group.

Perusal of the literature indicates that very few recognized authorities would admlt that the second generation of Chinese are lacking in the mental qualities necessary for cultural assimilation. Although the evidence of our findings seems to prove that the Chinese, in general, are not acquiring the culture of the whites, and that they are perpetuating to a large degree that of China, this evidence is not, by any means, conclusive. First, most of the adult Chinese belong to the flrst generation, while the second generation is made up almost entirely of minors. Cultural assimilation is never accomplished by any first generation. Second, the Chinese Immigrants have had very 11ttle opportunity to show their powers of cultural assim1lation.

Assimilation, however, to many people, does not mean merely the living together of two well-regulated groups in

2. Boddy, E.M., Japanese in America, 1921, p. 121-24 
the same community, but the fusing of the two into one. so far this has not been accomplished except through intermarriage. Thus many advocates of exclusion deny the possibility that Chinese can be completely assimilated in the sense of amalgamation into the larger group, since there is at present little or no inclination on the part of elther chinese or whites to intermarry. Th1s is particulerly evident with respect to the former in the Hawalian Islands, where there is no legal bar and relatively little soclal disapproval of intermarriage. The Chinese are very slow to marry outside their racial group in spite of the disproportionately small number of Chinese women in their population. Those who have married into the white race are usually severely criticized for so dolng. Their strong family ties and their custom of marrying as the elders of the family direct have militated against inter-racial marriages.

The attitude of the whites, on the other side, is shown by the passage, In nine states, of legislation prohibiting intermarriages between whites and orientals. The white race has never laid aside its color prejudice, while the Chinese on the contrary have an equaliy deep-seated fear of the loss of racial purity and prestige. Inevitably the assimilation is never complete as long as intermarriage does not take place and the difficulty of two races mentally accomodating themselves to one another, while maintaining each a separate racial existence, is bound to be verg great. Thus is pro- 
duced an unfortunate situation, and most serious from the national point of view, since the country must have a homogeneous c1tizenry for permanent stability and progress.

There are too few cases of intermarriage between these two races to warrant any conclusion as to the biological aspects of such unions. It 1s much more social and psychological problem than a blological one. Competent authorItles no longer believe that mixed races are "mongrel" or "degenerate" or "weaklings." The physical atamina of the offspring depends on the individuals who marry, not on their race. If the individuals who marry represent the best of each race, their children will normally measure up very well. Ethnologists today recognize that practically all existing nations are mixture of races.

But intermarriage is a very dangerous adventure unless there is psychological and soclal equality. Here $110 \mathrm{~s}$ another ghost behind race prefudice, for race prejudice is not only an 1rrational and unconsclous expression of lojalty to deeply cherished economic institutions, but also an oqually deep-seated fear of the loss of racial purity and prestige. Therefore intermarriage cannot develop extensiveIy unt1l both races have come to recognize each other as oqually worthy and honorable members of the great human race which includes us all. When this stage is reached, all valid reasons against intermarriage w1ll automatically disappear. 
II. THE CONQUEST OF RACIAI PREJUDICE

"HOw can race prejudice be overcome?" would seemingls by our next question if we want to succeed in bringing the two races to complete understanding of racial equality and assimilation. The following are a few suggestions which will lesson racial prejudice, if not eliminate it altogether.

A. Decrease in Occupational Competition

Racial prefudice should decline with decreasing competition in occupation. This has apparently occurred in California. Following the exclusion of the chinese they have largely withdrawn from occupations in which they competed with the whites.

B. Elimination of Racial Differences The elimination of racial differences is in harm mony with the psychological principle that human beings dislike to change their ways of doing things. They object to differences, for differences necessitate readaptation. This is much truer of older men than of younger ones, for the habits of the former are more strongly established. So racial differences in physical appearances and habits have always acted like a wet blanket on all efforts to bring about close and equal friendship and cooperation between the races.

It is very interesting to note how the physical bearing and even the facial expression of orientals born in this country are shifting in the American direction. Scientific atudies have demonstrated that chlldren of European immi- 
grants show body as well as mental changes toward the Amer13

can type. Professor Ichihashi of stanford reports that alm1lar adjustments are taking place among the orientals. For example, twelve jear old Japanese-American boys, on the average, are over an Inch and a half taller and five and four-tenths of a pound heavier than the bojs born in Japan. Japanese are notably short-legged, but their children tend to have longer legs in this country. Changes in eyelids and ejelashes are also evident, but the most noteworthy adjustment 18 in the shape of the mouth and general openness and responsiveness of the countenence. Whether these changes are due to the use of American furniture; food habits, better dentistry, general freedom of 11fe, or subconsc1ous 1m1tation of the dominant type, no one knows.

Although no sclentific study has been made of the children of Chinese Immigrants, no doubt these changes are also taking place among them. Allied with this is the ov1dent ability of the secondigeneration Orientals to wear their clothes like native-born Americans and not 11ke for. elgners. All these changes tend to create a new attitude toward the Orientals, and it is not too much to hope and believe that sooner or later, an enlightened and intelifgent American public opinion will discover that these Oriental jouths, born and reared among them, are not just replicas of

3. Boas, Franz, Anthropology and Modern Life, 1832, p. 42

4. Ichihash1, Yamato, Japanese In the United States, 1932, p. 417 
the old type forelgn-born Chinese or Japanese, but a new type.

C. Development of Cultural and Rac1al Democracy

It is always desirable that amalgamation should be so complete that all unita become approximately alike. Although people in general object to differences, jet there are some who crave changes. These two strikingly opposite principles of psychology account for style. Each jear's style 18 an outgrowth of some feature of last year's. In this way we change yoar by year our clothing, our autos, our belonglngs generally, but we never make a great change at one time. Such changes as take place represent a "happy mean" between uniformity and too great variety.

It is often desirable and pleasant to experience a more pronounced difference than that of this "happy mean." The value of travel lies largely in the fact that one 18 confronted with new experiences and is forced to adust himself and his thinking to them. Certainly much of the value of an education is to be explained on this basis. Is there not then something to be gained in having within a nation various racial groups which maintain their customs and tradtions? "We enjoy the deer in Kaibab Forest, the bears in Yellowstone, the Hop1 Indians at Grand Canjon, and Chinatown in San Franc18co. Why can't we enfoy the various national1ties as we meet them in everyday life just as we do when on a vacation to Honolulu or Quebec? We may well profit by being forced to adapt ourselves to new ways of living and new 
points of view." Indeed there are many advantages in adoptIng some of the favorable qualities of orientel culture into American $11 \mathrm{fo}$.

The feeling of racial superiority and prestige which many Americans have hinders greatiy the adoption of this point of view. The so-called "American Democracy" is painfully and traglcelly incomplete, limited only to political and industrial fields. There is no real cultural and racial democracy in America. Progress. Is therefore slow because many assume so absolutely that American views are the only true ones; hence all differences are signs of inferiority. The American public must learn that practical equality can exist with essential differences, and that differences do not imply inferiority. Development of cultural and social democracy will certainly help to bring about racial equality.

D. Extension of a Program for Social Contacts Racial prejudice should decline also as the ingroup come to know personally the members of the out-group, for when there is personal acquaintance, there is $108 \mathrm{~s}$ tendency to attribute to the ent1re out-group the characteristies of the individual who is known. And when the outmgroup has many fine qualities, as is the case with the Chinese, contact should further allay race prejudice toward them, if not eliminate it completely. Much tragic loss in cultural values has resulted from the fact that the whites and orien-

4. Strong, E.K., The Second-Ceneration Japanese Problem, $1934, p .257$ 
tals have had so for contacts with each other.

The Orientals and whites are often kept apart by racial prejudice, especially during the adolescent period. Even at the University of Hawa11, where students of all races may be seen dancing on the same floor, it is seldom that Chinese or Japanese dance with whites. Such segregation in social affairs makes assimilation slow, and in many places, almost 1mpossible. An extensive program for the development of social contacts as presented by Fisher and Akagi will greatlJ help to assimilate the Orientals into American $11 f \theta$.

\section{HOW CAN THE SOCIAL WORIERS HELP?}

It is true that many inter-racial activities have been carried on by the church, the Y.M.C.A., Y.W.C.A., and other similar bodies during the past century in many large citiea where the orientals have settled. But these religious agencies are entirely inadequate to bring about the final goal, namely, "Make the Chinese feel at home," without securing the support of the civic and social agencies and the cooperation of the chinese communities.

It has been the impression of the writer during his three jears' sojourn as an observer and traveller in manj American cities that the social and civic agencies are not cooperating very efficiently with religious organizations in community welfare projects. Many social workers are not in-

5. Fisher, G.M., Relations Between the Occidental and Oriental Peoples on the Pacific Cosst of North America, 1928, p. 10 6. Akagi, R.H., "The second Generation Problem," Japanese Students' Bülletin, May, 1926, p. 5 
terested in the activities which the religious bodies have undertaken to promote; certainly they have shown very little interest in the social problems existing among the Chinese residents in this country. The church, on the other hand, does not have an adequate appreclation of the work of the social groups; the1r work is too mechanical and worldiy. How can we account for this mutual antagonism between groups with admitted similar objectives? Certainly it would be admitted that the church w1th 1ts conception of the Fatherhood of God is the creator of the 1dea of the Brotherhood of Men. The objectives of the social groups are those of the church. The attitudes of mercy and equality of opportunity long promoted by the church find expression in the work of so-called "secular" social organizations. The church finds that the social groups have grown up as children that do not resemble their parents, hence it becomes susplcious. The social groups wonder how the church could be their fatherl Hence they go working side by side - but not too closely.

The church can be critlcized for its other-worldiliness. In the South, especially, religion is not put on the practical level; little emphasis is put on the social aspects of the principles so vehemently proclaimed. The emphasis is projected into the world to come rather than into the world at hand. The "saving of souls" is more important than Improving of conditions. Social activities of the church are poorly managed because their workers are well-meaning but poorly trained in the art of rehabllitation or racial ad- 
justment. On the other hand, the social groups do not work with the religlous groups in their projects of social improvement. The social worker tolerates the feeble attempts of the church with the secret hope that it will soon get out of the way and let him demonstrate how the job can be done well. Hence, the efficlency of both groups is curtalled at the expense of the people who so sorely need their joint assistance. The time has come for the church and the social workers to reallze their kinship and common objectives. The church would do well to emphasize 1ts soolal activitles and employ trained social workers in promoting such activities. The soctal workers, on the other hand, should drop their prejudices toward the church program, lend them every possible assistance, and partioipate with them in realizing their common objectives.

It is therefore the sincere desire of the writer and of many other Chinese Immigrants that the soc1al workers, representing the varlous civic and social agencles, shall take an intensive interest in the problem of assimilation of Chinese Imigrants by cooperating whole-heartedly with varlous reIIglous groups and Chinese community organizations themselves. Conferences with representative groups of chinese In America could develop an adequate technique for fulfiling the following necessary functions: (1) securing justice and sympathetic understanding for the Chinese in America, and (2) making the self-governing organizations of the Chinese in America channels through which America might in a greater way 
contribute to the social and economic upbuilding of the New China. The following agencies of Chinese in America might be ut1lized to make a fuller study of concrete and practical ways of securing these objects adequately; the Chinese student Associations, the Chinese Students' Christian Association, the Chinese Chamber of Commerce, the Chine Soclety, the Chinese Press, etc.

Soclal workers who are in cltles where the Chlnese have settled can also constructively alter the old pattern of race relations by promoting the following projects:

1. Participation of Chinese groups in the work of such organizations as the Parent-Teacher Assoclations, Cormunity Chest, League of Women's voters, Better Government Leagues, and similar organizations.

2. Work with local administrative officials to secure the inclusion of Chinese in public provisions for education, health, recreation and work.

3. Broadening of the study of race problem in high school and college courses in sociology.

4. Wide dissemination of Iiterature which can help acqualnt the general public with the correctable handicaps as well as the striking evidences of the cultural development of the Chinese.

5. The Inclusion of Chinese in cultural and economic advantages provided by the local community, whether these take the form of cooperatives or forums, musical programs or lectures. 
6. Provisions for the discussion of Chinese welfare in local communities and an equitable share in the measures developed for the rellef of the underprivileged. 7. Cooperation with local librarians to the extent of recommending or securing for general reading useful selection of books of poetry, novels and problem discussions dealing with the Chinese.

8. Work with organl zations of labor to insure the Inclusion of Chinese workers, as sound economic and labor policy.

9. Correction of infurious mis-statements in the press.

10. Active and polnted condemnation of such public crimes as mob violence and murder, the prostitution of the courts in response to racial prejudice, and the economic exploitation of defenseless minorities, not merely in the interest of these minorities, but in the interest of the morality of the nation 1tself.

11. Encouragement of constructive experiences, such as musical programs, poetry reading, Chinese opera and plays which utilize Chinese talent and racial experience.

12. Creation of occasions for meetings between the races, and the participation of Chinese individuals in public affairs.

This list should be continued, but is offered only as evidences of what social and welfare workers can do in makm Ing their professed concern for sociel justice and service 
find expression in practical action.

IV. THE ECONOMIC OUTLOOK

How are the second-generation Chinese going to earn a living? The question is largely a seculative matter at the present time. There are too many conflicting factors to make it advisable for anyone to set himself up as a prophot on this problem, and there are too few of the second generation of age to afford any real basis for judging what the remainder w11l do in terms of what these few are trying to do.

Anyone who is familiar with economic conditions of tom day realizes that we are living in a changing world. This 1s particularly true of the economic situation in America. The frontier days which gave much freedom of opportunity, competition among emplojers for the workmen available, elimInation of class distinctions, emphasis upon independence, resourcefulness, and, too often, brute force, are gone. The tables have been turned; there are more men than jobs. Indeed, the change from a sellers to a buyers market has revolutionized the whole American industry and commerce. The American publ1c has only recently become aware of the effect of this revolutionary change upon employment. What will the future be like? No one can se日. But certain results seem to be fairly clearly indicated.

First, freedom to move about from job to job will largely disappear. Th1s was possible when there were more jobs than men but will become much more difficult in the 
ruture.

Second, jobe per se w11l become more valuable. They had little value when the worker could get one as good or possibly better elsewhere at any time. From now on a man w11l strive to secure the next job before quitting; he will desire some consideration from the man who is to succeed him, before leaving.

Third, mere graduation from high achool and college w1ll become of less economic value because of the increasing supply of graduates. This will necessitate longer periods of preparation in order to secure through education an advantage over one's fellows.

Fourth, education will become more expensive, since it will necessitate a longer period of time and it will be harder for the average boy to obtain 1t. Odd jobs, by which today he earns part of the expense, w111 become more and more the rightful property of another.

Fifth, educated men will be forced into 1088 desirable positions. This may prove to be a great blessing to soclety, for many of these educated men will in time transform lowe class jobs into real positions.

Sixth, because no one can see far into the future, the best advice to the young is to prepare themselves as broadIy as possible - this is not a time for extreme specialization. Then if a job, or a whole industry, disappears over night, they will bo able to jump into a related activity for which they have had some preparation. If their educa- 
tion, on the other hand, is all narrowly directed toward one thing and that proves to be valueless, they have no recourse but to start all over again.

Lastly, the second-generation group must recognize that thelr progress will come by climbing the ladder of success, round by round. They should not foel that their falling to become captains of industry is due to the fact that they have not been given an equal chance or is due to race prejudice. It is true that the task of the orientals is infiniteiy harder than that faced by any European second-generation; but in looking at the question from its broad aspects, there is a great aimilarity. If we were to use that analogy, we find that even in the vocational advance of European Imm1grants, there have been but few who have jumped from the lowest to the highest stratum in one jump. There have been a Carnegle, a Schwab, a Bok, a Pupin, and a Rils, but as a whole the great mass of European Immigrants are st1ll of the middle class. Therefore, the second-generation Chinese should by no means be disappointed if they do not reach the standard of their lofty vocational dreams. Many of the second-generation Chlnese are ambitious and progressive people; some have already made remarkable progress in their vocational fields. But as a group, they have no right to expect more than that a few will accomplish great things and the remainder will build upon the foundations established by their fathers. Their success will be measured by the distance they progress from where the first genera- 
tion stop and by the varlety of directions in which they advanos.

V. A FINAL WORD

We are living today in a time when economic and moral chaos seems ready to engulf the world. Europe is talking warl Dictatorshlp and violence, the persecution of minority pooples and a nationalism which bids fair to enthrono itself as a secular religion, these are the false gods of the hour. Such a time is Iraught with peculiar perils to minority groups such as the Chinese in the United States of America. No one can tell when some new madness of nationalistic passion, some seductive form of blind and selfish racial egotism, may rise up to sacrifice new victims to intolerance and persecution. Already within a short period of time, many Filipinos have been killed in California, Chinese driven out of Mexico, the Jows treated abominably in Germany, and hundreds of thousands of Chinese living in China massacred by flerce, barbarous, blood-thirsty Japanese soldiers. Certalnly now 1s the day of testing for Christian America.

What, then, will keep America free from violence and war, from greed and commercial exploitation of human beings, especially the minority groups within 1ts borders? A bit of reflection about the facts of its own birth as nation of minority groups who sought for a land of freo speech, freedom of conscience, and freedom of opportunity will forever - if it retains its ability to think - keep it tolerant and brotherly. It is trite to speak of the fact that there is 
no such person as an "Amerlcan" in the common meaning of the term - he is a cholce product of the amalgamation of minority groups moving forward toward great objectives in terms of brotherhood. "The land of the free and the home of the brave." The principles of love must be promulgated by the brave in the political, social and economic relationships of the nation. If the high and unconquerable purpose of human brotherhood be maintained in American 11fe, all will be well with the minorIty groups. This applies to Chinese immigrants in America. America has long been known to the Chinese millions as a Christian nation built upon the principle of democracy and the motto of "Thou shalt love thy neighbour as thyself." The spirit of brotherhood and good will among Chinese people has been expressed by the oft-quoted proverb of Confuclus: "Within the four seas all are brethren." May the four hundred and sixty-six millions of Chinese and the one hundred and twenty-three millions of Americans who together const1tute more than one-fourth of the human race 11 ve and prom claim the herolc and absolutely central truth of human brotherhood. Th1s ldeal will carry far and will bring a better day for all mankind. 
BIBLIOGRAPHY

$+$ 


\section{BIBLIOGRAPHY}

This is not by any means a complete bibliow graphy on the subject of Oriental Imigration. It is simply a list of publications which contained valuable materials consulted by the writer in the preparation of this thesis. Some of these books are out of print, but many will be found in public libraries. Included in the bibllography are the names of a number of organizations and bureaus which will be glad to furnish materials as far as they are able. Most of the material was dated, but in some instances no dates were given. 


\section{BOOKS}

Adams, Romanzo, Interracial larriage in Hawail, liachillan, Hew Tork, 1937

Allport, F. H., and Katz, D., Students' Attitude, Craftsman Press, New York, 1931

Bancroft, $\mathrm{Y}$. H., History of Califormia, VoI. XXIV, 1890 .

Bercovia, K., On New Shoes, The Century Co., New York, I9 25

Bill, Reginald, Public School Education of SecondGen eration Japanese in California, 1930

Beach, Walter G., Oriental Crime in California, Stanford University Press, Stanford University, California, I932

Boaz, Franz, Anthropology and hod erm Life, W. W. Norton \& Co., New York, 1932

Boddy, E. it., Japanese in Amerlca, 1921

Bogardus, Emory S., Immigration and Race Attitudes, Health, New York, 1928

Introduction to Social Research, Suttonhouse, New York, 1936

Brown, Lawrence Guy, Immigration: Cultural Conflicts and Social Adjustments, Longmans, Tew York, $19 \overline{93}$

Camp bell, P. C., Chinese Coolie Immigration, 1922

Carter, E. C., China and Japan in our University Curriculum, American Council, Institute of Pac Ific Relations, New York, 1929

Carver, W. 0., The Course of Christian Missions, Revell, New York, I932

Castle, Nilliam R., Hawaii, Past and Fresent, Dodd and liead, New York, I927 
Cleland, R.G., A History of California: The American Period, 1922

Coolidge, Mary Roberts, Chinese Immigration, Holt, New York, 1909 (out of Print)

Crawford, David L., Can Nations Be Neighbors? Stratford, Boston, 1933

Davis, M.R., World Immigration, Machillan, New York, 1936

Dodd, M.E., Girdling the World for God, John S. Raymond Publisher, Shreveport, Loulsiana, 1935

Dobie, Charles Caldwell, San Francisco's Chinatown, D. Appleton - Century, San Francisco, 1936

Dressler, A., California Chinese Character, The Author, 2263 Geasy St., San Francisco, California, 1925

Duncan, H.G., Immigration and Assimilation, Heath, New York, 1933

Embrie, E.R., Brown America, Viking Press, San Francisco, California, 1931

Feldman, H., Racial Factors in American Industry, The Association Press, New York, I931

Fisher, G.M., Relations Between the Occidental and Oriental Peoples on the Pacific Coast of North America, International Hissionary Council, New York, 1928

Foreign Student in America, The Association Press, New York, 1925

Garis, Roy L., Immigrant Restriction, MacMillan, New York, 1927

Gong, E.Y., and Grant, B., Tong War! Brown, New York, 1930

Gullok, Sidney L., The American-Japanese Problem, 1914, American Democracy and Asiatic CItizensh1p, 1915, Federal Council of Churches, New York 
Hitti, P. K., The Syrians in America, 1920

Hoffman, W. G., $\underset{\text { New }}{\text { Paciflc }}$ York, Relations, lioGraw Hill,

Home Missions Today and Tomorrow: A Review and Forecast, Home Miss Ion Council, 105 East 2 nd street, New York, 1934

Huie, Kin, Reminiscences, San Yu Press, Peiplng, China, 1932. Aval able from Presby terian Books tore, 234 inc Allis ter St., San Francis co, Cal if ormia

Funter, Allan A., Out of the Far East, Friendship Press, New. York, 1934

Ichihashi, Yamato, Japanese in the United States, Stan ford University Press, Stanf ord University, California, 1932

Johns on, Charles, S., A Preface to Racial Understanding, Friendship Prēss, New York, 1936

Johnsori, Julia, E., China Yesterday and Today, 1931

Kuykendall, R. S., A His tory of Hawa11, Hachillan, New York, 1926

Kwei, Chung-Shu, The Uhinese Year Book, The Commercial Press, Shangha1, $193 \overline{5-36}$

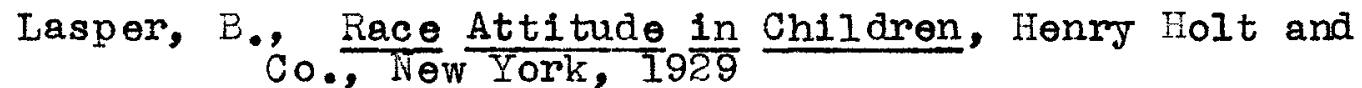

Iippmann, Walter, Public Opinion, Macilillan, New York, 1922

Lin, Yutang, My country and Hy People, Reynal and Hitcheock, New Tork, 1935

Nathews, Basil, World Tides $\frac{\text { in }}{\text { ship }}$ the Far East, Friend-

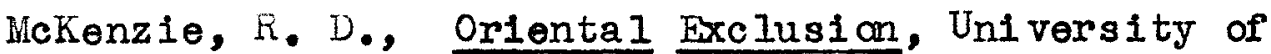
Chicago Press, Chicago, 1927 
Wears, Eliot Grinnell, Resident Orientals on the American Pacif ic Coast, University of Chicago Press, Chicago, 1928

iilils, H. A., The Japane se Problems in the United

Oldham, J.H., Christianity and the Race Problem, The Association Press, New York, 1930

Ou-Yang, Kie, Chinese Immigration (in Chinese), 1915,

Palmer, Albert W., Orlentals in American Life, Fri endship Press, New York, 1934

Payne, Philip F., Gold Mountain, Friendship Press, New York, 1934

Porteus, S. D., The Psychology of a Primitive People, Longmans, Gre日n and Co., New York, 1931

Rawlins on, Frank, China Christian Year Book, The Chinese Recorder, Shanghai, ChIna, 1934-35

Reut er, E. B., Race and Race Contacts, MicGraw-Hill, New York, $1 \overline{934}$

Sears, J. B., Sacramento School Survey, Houghton inffin, New York, 1928

Shepherd, Charles R., Iim Yik Choy, 1932; The Ways of Ah Sin, 1923; Revel1, New York

Stratton, G. in., The Social Psychology of International Conduct, D. Apploton Contury Co., Now York, 1929

Strong, E. K., Vocati onal Aptitudes of Second-Generation Japan ese in the United States, 1933; The Second Generation Japanese Problems, 1934; Stanford University Press, Stanford Universi ty, California

Sumner, William G., Folkways, Ginn, Boston, 1907

Sun, Yat-Sen, San Hing ohu, I, The Commercial Press, Shanghat, 1927

Taft, Dona ld R., Human Migration, The Ronal d Press, New York, 1936 
Takamine, Eken, J., Employment of Second-Generation Japanese in New York CIty, 1928

Tang, Leang-11, Reconstructi on in China, China United Press, Shangha1, 1935

Thornton, H. W., Men and Industry, (A Brackett Lecture at Princeton University), Princeton University Press, Princeton, N. J., 1931

Treat, Pays on, J., The Far East, Harpers, New York, 1937

Vernier, C. G., Americ an Family Lanes, Stanford University Press, Stanford Un1versity, Cal Iforn1a, 1931

Weatherford and Johnston, Race Relations, Health, New York, 1934

Wo1, Ching-Yen, The United States and China, The Commercial Press, Shangha $\overline{1,}$ ChIna, 1930

Wilson, Carol Green, Chinatown quest, Stanford University Press, Stan ford University, Calif ornia, 1931

Woof ter, T. J., Races and Ethnic Groups in Americ an Iffe, McGraw-Hill, New York, I933

Young, Donald R., American Minority Pooples, Harpers, New York, 1932

Young, K., ${ }_{\text {Co }} \frac{\text { Source }}{\text { NeW }} \frac{\text { Book }}{\text { York, }}, \frac{f o r}{193} \frac{\text { Soc lology, American Book }}{5}$

PAHPHIETS

Aliens in the United States, J. P. Chamberlain, American Council of the Institute of Pacific Relations, Now York, 1931

American Foreign Relationg, American Council on Foreign Relations, New York, 1930

A Guide to the Study of Orientals in the United States, Margaret I. Marston, Council of Women for Home int is sil ons, New York, 1934

Allens and Alien-Baiters, Lou is Adamic, Reprinted from Harpers Magazine, Vol. 173, Harpers, New York, November, 1936 
Interracial Contacts-Orientals in Americ a, Sterling T. Takeuchi, The Book Store, Church Wiss ions House, 281 Fourth Ave., New York

Missi mary Review of the World, The, 156 Fifth Ave., New York, June, 1934

Orient and Occident, G. B. Watson, Americ a Council of the Institute of Pacific Relations, New York, 1927

Proceedings of the Institute of Paciflc Relations, University of Chicago Press, University of Chicago, 1931

Population Problems in the South, Conference on Educatonal Race Relations, 710 Standard Bullding, Atlanta, Ga., 1937

Quota Provisions of the $\frac{\text { Immigrant }}{\text { Act }}$ of 1924 ,

Race and Race Relations, American Council of the Inst1tute of Pacific Relations, New York, 1931

Second Gengration Orientals in America, The, William C. Smith, Institute ô Pacific Relations, Honululu, 1927

Soc1al Psychology of Oriental-Occidental Prejudices, The, Kimball Young, Institute of Pacific Relations, New York, 1929

Some Reasons for Chinese Exclusion, Amerlcan Federation of labor, New York, 1905

Theories of Americanization, Isaac Berkson, Teacher's ColIege Contribution to Educ ation, No. 109, Columbia University Press, New York, 1920

Tentative Findings of the Survey of Race Relations, 1925

Pemperament and Mentaity in Maturity, Sex and Race, S. D. Porteus, reprinted from Journa I of Applied Psychology, Vol. 8, No. 1 March, 1924

Unofficial Amba ssadors, The, Commit tee on Fritendly Relations Among Foreign Students, 347 hadison Ave., New York, 1931, 1932, 1933, 1934, 1935, $1936,1937,1938$ 
Annual Report of Nation al Council of High Education, Nationa I Christian Cound I of China, Shangha i, China, 1935

Bulletin of the American Council, Institute of Pacific Relations, New York, Nov. 3, 1933

Brief Summaries for Busy Hen and Women on the International Relations of the United States of America, Commission on International Justice and Goodwill of the Federal Council of the Churches of Christ in America, 105 East 22nd St., New York, 1932

Chinese and Japanese in America, American Academy of Political and Social Service, New York, 1909

Chinese Population in Hawail, H. I. Shapiro, Ins titute of Pacific Relations, Now York, 1931

Chinese Students' Christian Association Year Book, Chinese Students Christian Association in North America, 347 hadis on Ave., New York, 1926-27

Ching Speaks, Shing Ioung Chau, San Ming Morni ng Paper, Chic ago, 1938

China Faces Japan, Arthur A. Young, Chinese Students' Christian Association in North America, 347 Madis on Ave., New York, 1937

Directory of Chine se Students in America, 1937-38, Chinese Students Christian As ociation, 347 Madis on Ave., New York, 1938

Forelgn Students in U. S. A., Char les D. Hurrey, 347 hiadis on Ave., New York, 1938

Further Developments of Race Contacts in Eawail, Romanzo Adams, Institute of Paific Kelations, New York, 1930

Foreigners in Our Midat, The, J. B. Lawrence, Home Hiss ion Board of Southerm Baptist Convention, Atlanta, Georgia, 1935

Imigration Restriction, University of North Carolina Record, Extension Series No. 34, Universi ty of North Carolina Press, Chapel Hill, N. C., 1919 
Yearly Calendar and Members' Directory, Philip Lee, Chinese Christian Union Church, Chicago, Illinois, 1937

ARTICLES

Aiso, Paul, "Vocational Opportunities of the SecondGeneration in America," Nikke1 Shimin, Way 15, 1930

Akag1, R.H., "The Second-Generation Problem," Japanese Student Bulletin, Kay, 1926

Adams, Romanzo, "Some Racial Statistics on Hawail," Foreign Affairs, Vol. II, 1923

Bramhall, J.T., "The Orient in California," World Today, April, 1911

Bogardus, E.S., "Social Distance, A heasuring Stick," Surver Graphic, Vol. IVI, 1926

Bogardus, E.S. "Social Distance and its origins," and "Measuring Social Distance," Journal of Applied Soclology, Vol. IX, 1925

Chu, J.P., "ChInese Students in America," Teacher's College Record, Vol. XXIII, No. 8, May, 1922

Davis, J.H., "Wo said: "Let's Find the Facts," Survey Graphic, Vol LVI, 1926

Darsie, M.L., "The Mental Capacity of American-born Children," Comparative Psychology Lonographs, Vol. III, No. 15, 1936 
Graham, V. T., "The Intelligence of Children in San Francisco," Journal of Compara tive Psychology, Vol. VI, 1926

Hurrey, Charles D., "Annual Report of the Committee on Friendy Relations Among Foreign Students," Chinese Christian Student, The, Vol. XXVIII, Nos.4-5, 1938

Jones, "Cathay on the Coast," Americes Mercury, No. 8, 1926

Kazuo, Kawa1, "Three Roads and None Easy," Survey Graphic, Vol. LVI, 1926

Kanzaki, "Is Japanes e Menace in America a Reality?" Annals, the American Academy of Political and Social Scienc , Vol. XCIII, Jan. 1921

Miears, E. G., "The Lord, the Crops, and the Orient," Survey:Graphic, Vol. LVI, 1926

Nears, E. G.,. "California's Attitude. Towards Orientals," Annals, American Academy of Political and Soc1al science, Vol. CXXII, Nov. 1925

Myers, A. J., "Lit erature for Children and Its Influence," Religious Education, Apri1, 1936

McKenzie, $R$. D., "The Oriental Invasion," Journal of Applied Sociology, Vol. X, Nov. - Dec., 1925

Rowe11, C. H., "Western WIndows to the East," Surver Graphic, Vol. LVI, May, 1926

Sm1th, H. E., "The Direction of Reading and the Effect of Foreign-Language School Attendance on

Leaming to Read," Joumal of Genetic PsychologY, Vol. XI, No. 2, June, 1932 
Steiner, J.F., "Some Factors Involved in Minimizing Race Friction on the Pacific Coast," Annals, American Academy of Political and Social Science, Vol. X XCIII,

Shepherd, C. R., "Chinese Girl Slavery in Amer Ica," Mission Review of the World, Vol. 46, 1925

Shepherd, C. R., "Fathers of Chinese Jourmalism in America," Chinese Christian Student, The, Silver Anniversary Bulletin, Vol. XXV, No. 7,1934

Thurs tone, L. I., "An Experimental Study of Nationali ty Preferences," Journal of General Psychology, Vol. I, 1928

Wolcott, C. 0., "The Intelligence of Chinese Students," School and Society, Vol. XI, 1920

Young, K. T., "The Intelligence of Children in San Francisco and Vicinity," Journal of Applied Psychology, Vol. V, I921

Young, Arthur, A., "Yung WIng - First Chinese Student Argonant to America," Chinese Christian Student, The, Vol. XXV, No. 7,1934

UNPUBLISHED MATERIALS

Bill, Reginald, "A Study of the Educational Effects of Segregation Upon Japanese Children in American Schools," An unpublished Ph. D. thesis, Stanford University, 1933

Fan, Ting Chin, "Chinese Residents in Chicago," An unpublished $\mathrm{M}$. A. thesis at the University of Chicago, 1925

Reynolds, C.N., "Oriental-white Race Relations in Santa Clara ounty, Callformia," an unpublished $\mathrm{Ph}$. D. thesis, Stanford University, 1927

Wu, Ching, Chao, "Chinatowns," an unpublished $\mathrm{Ph}$. D. dissertations at the University of Chicago, 1925 
GOVERNMENT DOCUMENTS

Annual Report of the Commissioner-General of Immigration, 1919, pp. 53-54; 1924, pp. 156-160

Admissin of Chinese Students to American Colleges, John Irryer, U. S. Bureau of Education, Bulletin No. 2, 1909

California and the Orient, Report of State Board of control to the Governor, 1920

California Juvenile Court Law, 1919

Congressional Record: Containing the Proceedings and Debates of the Forty-third Congress, March 4, 1873

Journal of the Senate (3rd Session, 1852), pp.669-675

Remarks in Senate, David A. Reed, April 9, 1924

Rep ort of the U. S. Industrial Commission, 1901 VoI. XV, p. T79ff.

Report of the Commissioner General of Immigration for the fiscal year, 1924, p. 156

Reports of the Los Angeles County Juven1le Hall, 1929

Testimany of Char les Crocke in 1877, U. S. Senate Report, No. 689

Treaties and other International Acts of the United

States of America, Edited by Hunter Miller, Vol. 4, Document 109, pp. 559-562, U.S. Government Printing office, Washington, 1934

U. S. Immigration Commiss ion Repa ts, Vol. 23, p. 13, 1907-10

U. S. Bureau of Immigration Hearings, 1925

U. S. Document, Serial Number 4903, House Journal (59th congress-first sersion)

U. S. Census, 1870, 1890, 1920, 1930 